\title{
SOCIOECONOMIA E \\ PESCA RIBEIRINHA
}

VOLUME I

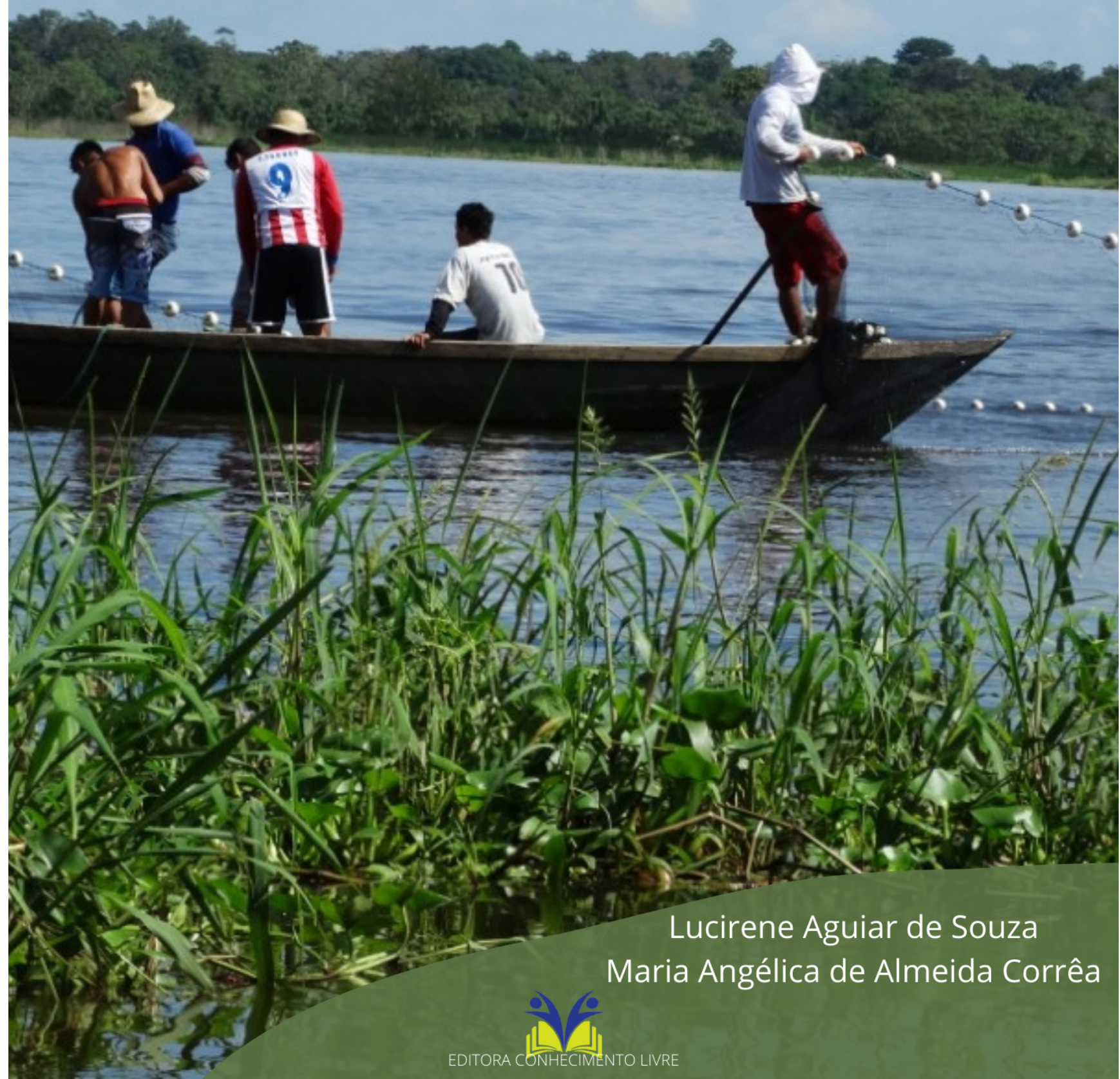


LUCIRENE AGUIAR DE SOUZA

MARIA ANGÉLICA DE ALMEIDA CORRÊA

SOCIOECONOMIA E PESCA RIBEIRINHA

$1^{\text {a }}$ ed.

Piracanjuba-GO

Editora Conhecimento Livre

Piracanjuba-GO 
$1^{\mathrm{a}} \mathrm{ed}$

Dados Internacionais de Catalogação na Publicação (CIP)

\section{SOUZA, LUCIRENE AGUIAR DE
S719S}

/ LUCIRENE AGUIAR DE SOUZA. MARIA ANGÉLICA DE ALMEIDA CORRÊA. Piracanjuba-GO

Editora Conhecimento Livre, 2021

76 f.: il

DOI: $10.37423 / 2021$. edcl 342

ISBN: 978-65-89955-67-2

Modo de acesso: World Wide Web

Incluir Bibliografia

1. pesca-manejo 2. recursos-pesqueiros 3. amazônia-brasileira I. SOUZA, LUCIRENE AGUIAR

DE II. CORRÊA, MARIA ANGÉLICA DE ALMEIDA III. Título 


\title{
EDITORA CONHECIMENTO LIVRE
}

\section{Corpo Editorial}

\author{
Dr. João Luís Ribeiro Ulhôa \\ Dra. Eyde Cristianne Saraiva-Bonatto \\ Dr. Anderson Reis de Sousa \\ MSc. Frederico Celestino Barbosa \\ MSc. Carlos Eduardo de Oliveira Gontijo
}

$\underline{\text { MSc. Plínio Ferreira Pires }}$

Editora Conhecimento Livre

Piracanjuba-GO 


\section{APRESENTAÇÃO}

A obra "Socioeconomia e Pesca Ribeirinha" aborda uma série de capítulos relacionados com os meios de produção de populações amazônicas, com foco na atividade pesqueira. Apresenta, em seus cinco capítulos, conhecimentos sociais, econômicos e ecológicos sobre a pesca e estilo de vida ribeirinha dos povos amazônidas. O Amazonas é um estado onde a pesca é fundamental para segurança alimentar da região. Consequentemente isso se reflete na necessidade de acompanhamento contínuo das pescarias bem como das atividades relacionadas e do desenvolvimento de estudos científicos que possam tornar essa atividade sustentável e rentável para aqueles que a executam, sem, contudo, afetar a sustentabilidade dos estoques. Novos estudos e a divulgação dos resultados de pesquisas são vitais para completar lacunas de conhecimentos e a difusão do mesmo, uma vez que muitos estudos nunca são publicados na língua materna, dificultando a acessibilidade de informações para todos os interessados no setor pesqueiro. É nesse sentido que este livro traz uma coletânea de artigos sobre essa temática tão relevante para o Estado do Amazonas, para os administradores pesqueiros, para os estudiosos dessa temática e populações que desse recurso fazem uso. Deixo aqui, meus agradecimentos aos autores dos diversos capítulos, pela dedicação e esforços que viabilizaram esta obra. Assim como para as populações ribeirinhas do Estado do Amazonas, por terem fornecidos informações tão importantes para a compreensão dor seu estilo de vida e por administrarem os recursos naturais tão importantes na nossa região, principalmente os recursos pesqueiros. Por último, esperamos que esta obra possa estimular mais estudantes e pesquisadores na constante busca sobre a compreensão do modo de vida das populações tradicionais, e assim gerar subsídios para garantir perspectivas de solução para o desenvolvimento regional e de possibilitar futuras medidas de administração dos recursos pesqueiros de forma sustentável. 


\section{LUCIRENE AGUIAR DE SOUZA}

Professora Associada II da Universidade Federal do Amazonas, instituição na qual se graduou em Engenharia de Pesca em 2001, fez mestrado (2003) e doutorado (2007) em Biologia de Água Doce e Pesca Interior no Instituto Nacional de Pesquisas da Amazônia. Tem experiência na área de Recursos Pesqueiros e Engenharia de Pesca, com ênfase em Modelagem Pesqueira de Águas Interiores, atuando principalmente nos seguintes temas: pesca, modelagem pesqueira, modelagem de ecossistemas, tecnologia de pesca, estudo de impacto ambiental e produção pesqueira. Coordena o Laboratório de Navegação e Tecnologia de Pesca e o Embarque Oceanográfico no Navio de Ensino e Pesquisa no Mar (NEP) no âmbito da UFAM. Orcid: 0000-0001-5832-8023

\section{MARIA ANGÉLICA DE ALMEIDA CORRÊA}

Doutora em Ciências Pesqueiras nos Trópicos e formada em economia, atua como docente na Universidade Federal do Amazonas (UFAM) desde 2009. É professora ajdunta do curso de Engenharia de Pesca e desenvolve pesquisas nas áreas de Economia pesqueira, Socioeconomia, Economia de recursos naturais, Sistemas sócio-ecológicos e governança. Trabalha com as comunidades pesqueiras na Amazônia, participando de projetos de excelência (PRONEX) e ecológicos de longa duração (PELD), em colaborações institucionais. Coordena o Laboratório de Economia e Administração Pesqueira na UFAM. 


\section{SUMÁRIO}

CAPÍTULO 1

PRODUÇÃO PESQUEIRA E ORIGEM DAS ESPÉCIES DE PEIXE DESEMBARCADAS EM

MANAUS-AMAZONAS PELA PESCA ARTESANAL COMERCIAL

Cássia Cristina Esquerdo de Souza

Wildes Cley da Silva Diniz

Lucirene Aguiar de Souza

DOI 10.37423/210904734

CAPÍTULO 2

PESCA EM UNIDADES DE CONSERVAÇÃO NA AMAZÔNIA CENTRAL

Bruna Barbosa Alves

Vinícius Verona Carvalho Gonçalves

Lucirene Aguiar de Souza

Maria Angélica de Almeida Corrêa

DOI 10.37423/210904735

CAPÍTULO 3 34

VARIAÇÃO ESPACIAL E SAZONAL DA PESCA DE MATRINXÃ (BRYCON SPP.)

DESEMBARCADO EM MANAUS-AM

Glenda Katherine de Souza Dias

Lucirene Aguiar de Souza

DOI 10.37423/210904736

CAPÍTULO 4

VARIAÇÃO ESPACIAL E SAZONAL DA PESCA DO JARAQUI (SEMAPROCHILODUS SSP.)

DESEMBARCADO EM MANAUS/AM

Williams Ricardo Neves da Cunha Junior

Sãmea Coelho Bezerra

Lucirene Aguiar de Souza

DOI 10.37423/210904737

CAPÍTULO 5

VARIAÇÃO SAZONAL DO CONSUMO PROTEICO ANIMAL NA REBIO ABUFARI

(TAPAUÁ/AMAZONAS)

Adailson Freire dos Santos

Lucirene Aguiar de Souza

Maria Angélica de Almeida Corrêa

DOI 10.37423/210904738 


\section{Capítulo 1}

\section{doi $10.37423 / 210904734$}

\section{PRODUÇÃO PESQUEIRA E ORIGEM DAS} ESPÉCIES DE PEIXE DESEMBARCADAS EM

\section{MANAUS-AMAZONAS PELA PESCA ARTESANAL COMERCIAL}

Cássia Cristina Esquerdo de Souza

Wildes Cley da Silva Diniz

Lucirene Aguiar de souza

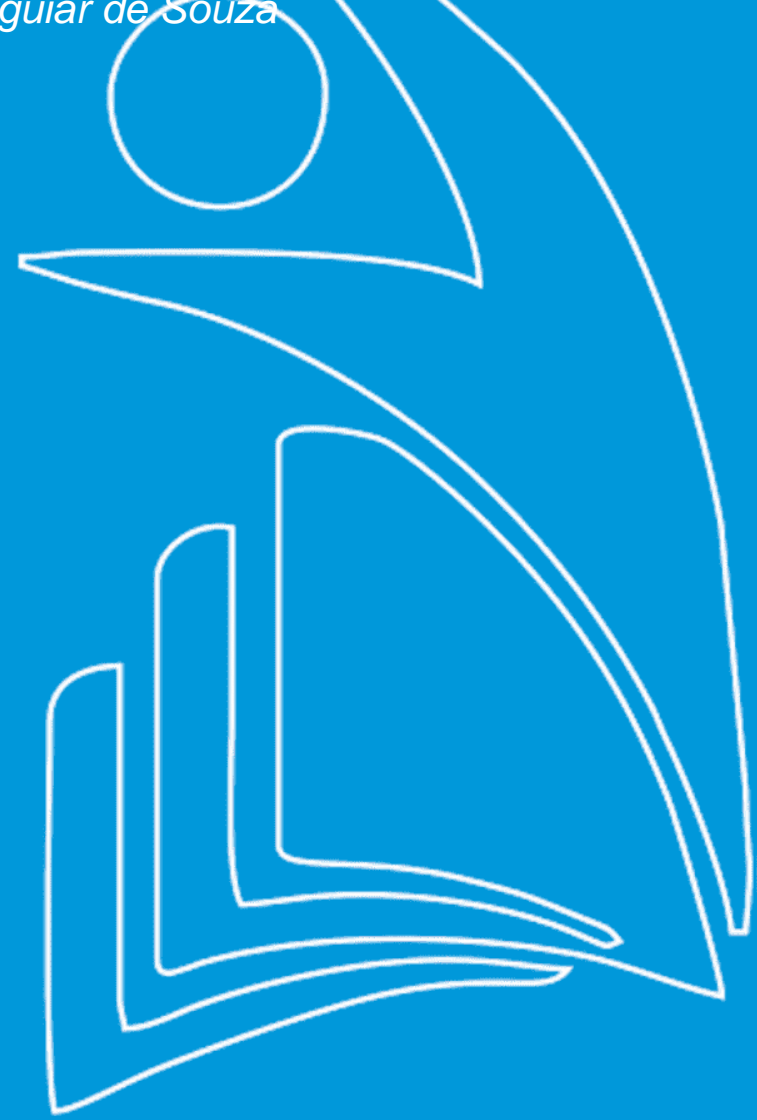

Graduando em Engenheiro de Pesca,

Universidade Federal do Amazonas

Mestre em Ciências pela COOPE/UFRJ. Universidade Federał de Oeste do Pará

Doutora em Biología de Águra Doce e Pesca Interior, Plofessqra Associada ola FCAVUFAM 
Resumo: A definição das zonas de pesca das espécies desembarcadas no Amazonas são fundamentais para o gerenciamento das pescarias. Desta forma, este trabalho visa a definir a origem das principais espécies alvo das pescarias desembarcadas em Manaus, principal área de produção pesqueira da Amazônia Central. Os dados sobre espécies e sua origem foram disponibilizados pela Colônia de Pescadores Z-12, que correspondem aos desembarques no Porto da Panair em Manaus/AM. Os dados foram analisados a luz das análises descritivas. As principais espécies capturadas são provenientes de um total de 40 ambientes de pesca diferentes. Os rios de água branca são os ambientes que mais contribuem para o desembarque na cidade de Manaus, com destaque para o rio Purus e o Solimões. As espécies com maior quantidade desembarcada são o jaraqui, a matrinxã, o curimatã, o pacu, o tucunaré e o tambaqui.

Palavras-chave: Zonas pesqueiras; Espécie capturadas; Ambiente de pesca. 


\section{INTRODUÇÃO}

A Amazônia é destaque no mundo todo por sua elevada biodiversidade e abundância de recursos naturais. Entre tantos atributos ecológicos aplicados a região, ela destaca-se por abrigar a maior diversidade de peixes de água doce de todo o mundo (SANTOS et.al, 2008). Estima-se que somente a bacia amazônica abrigue entre de 3.000 a 8.000 espécies de peixes (LEAL et al., 2018).

Dos recursos pesqueiros da região, 89 peixes são explorados pela pesca, sendo que foco está concentrado em 37 grupos, dos quais 18 são de escamas e 17 de couro, chamados de bagres (FARIA JR e BATISTA, 2019), que abastecem principalmente o mercado local. A população amazônica é responsável pelo maior consumo de pescado em todo o mundo, sendo aproximadamente 400 a $600 \mathrm{~g} /$ pessoa/dia, sendo que em nível de Brasil, o consumo médio de pescado é de apenas 20g/pessoa/dia (SANTOS et. al, 2008).

O crescimento populacional desta região aumenta a demanda por pescado, o que pode colaborar para que os estoques pesqueiros amazônicos sejam cada vez mais explorados (MONTENEGRO e SOUZA, 2016), gerando a queda do estoque e consequentemente diminuindo a quantidade de ambientes aptos a exploração para essa atividade (CASTELLO et al., 2011). Dessa forma, este trabalho se propõe a analisar quais as principais espécies alvo das pescarias desembarcadas em Manaus, principal ponto de desembarque pesqueiro da Amazônia Central, e a sua origem.

\section{MÉTODO}

\section{ÁREA DE ESTUDO}

O trabalho foi realizado com dados de produção oriundos da Amazônia Central (Figura 1), uma região importante no aspecto socioeconômico, pois abastece o principal centro consumidor de pescado, Manaus. A Amazônia Central possui um extenso território, abrangendo o centro e o Oeste do Pará e o leste do Amazonas. 


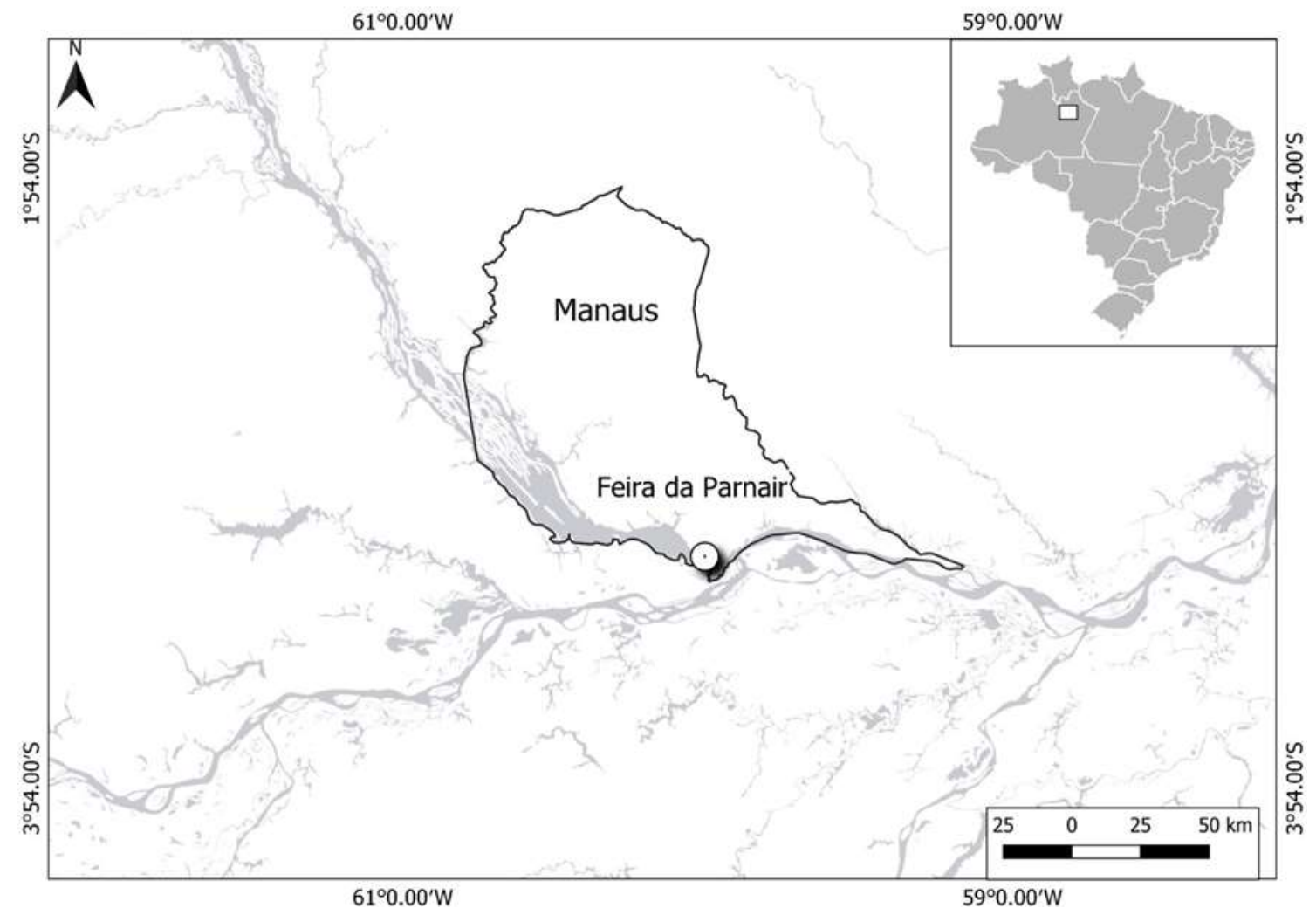

Figura 1: Trecho da Amazônia Central com destaque para Manaus e Feira da Panair

\section{COLETA DE DADOS}

Os dados de desembarques foram fornecidos pela Colônia dos Pescadores Z 12, que coletava estes dados na feira da Panair, principal ponto de desembarque pesqueiro de Manaus. Este órgão obtinha as informações diariamente no momento em que os pescadores se aproximavam para venda do pescado. Os anos disponibilizados para análise são de 2012 e 2013. As informações obtidas correspondem ao número de barcos por local de pesca, quantidade desembarcada em quilogramas por espécie. Os dados foram disponibilizados em forma de planilha e eletrônica.

\section{ANÁLISE DE DADOS}

Os dados usados nesse trabalho foram filtrados, organizados e construídos gráficos, para proporcionar a análise por meio de estatística descritiva das: principais áreas de captura, verificadas pela frequência de citações pela frota que desembarca em Manaus, bem como das espécies capturadas. Foi dado ênfase as principais espécies desembarcadas de acordo com a quantidade em peso. Os ambientes de pesca citados foram procurados na literatura ou no Google Earth para verificar se existia concordância entre os nomes citados. 


\section{RESULTADOS E DISCUSSÃO}

Foram verificados 40 ambientes de pesca entre rios e lagos da Amazonia Central que foram usados como pesqueiros. Alguns rios citados pelos pescadores não foram achados na literatura ou no Google Earth, e dessa forma, pela semelhança dos nomes, acreditamos que o "rio Puí" seja a redução de Puinicici, pois somente esse último foi encontrado. Outros ambientes de pesca apresentavam nome parcialmente diferenciado daqueles citados pelos pescadores, como o rio Sapatini descrito pela colônia foi encontrado como Sapetini. Alguns colocados como rios são na verdade paranás, ou seja, braços de rio, como o Parauá, o Aranapú, o Copea, o Mamori e o Curari, além disto este último ambiente de pesca foi encontrado nos mapas como Curari Grande.

É importante ressaltar que as embarcações exploram vários rios e lagos durante cada campanha de pesca, visto que estas podem durar até dois meses dependendo da embarcação. Dessa forma, talvez os nomes dos pesqueiros apresentados a colônia sejam aqueles onde ocorreram as principais pescarias ou se refiram ao último destino da viajem.

As principais espécies comercias desembarcadas no porto de Manaus são semelhantes as descritas por Faria Junior e Batista (2019). A maior parte da captura neste trabalho observada se enquadra nos peixes identificados por esses autores como as mais capturadas na região, destacando-se o jaraqui (Semaprochilodus spp.), a matrinxã (Brycon amazonicus), o curimatã (Prochilodus nigricans), o pacu (vários Myleinae) e o tucunaré (Cichla monoculus) (FARIA JUNIOR e BATISTA, 2019). Estas espécies estavam entre as 12 mais capturadas nos dois anos testados (2012 e 2013) (Figura 2 e 3). Não foi possível identificar por espécie os peixes capturados uma vez que apenas são mencionados o nome vulgar, e dessa forma muitas espécies podem ser representadas por um único nome. Este é o caso das "feras" que aqui representam todos os Siluriformes da região. 


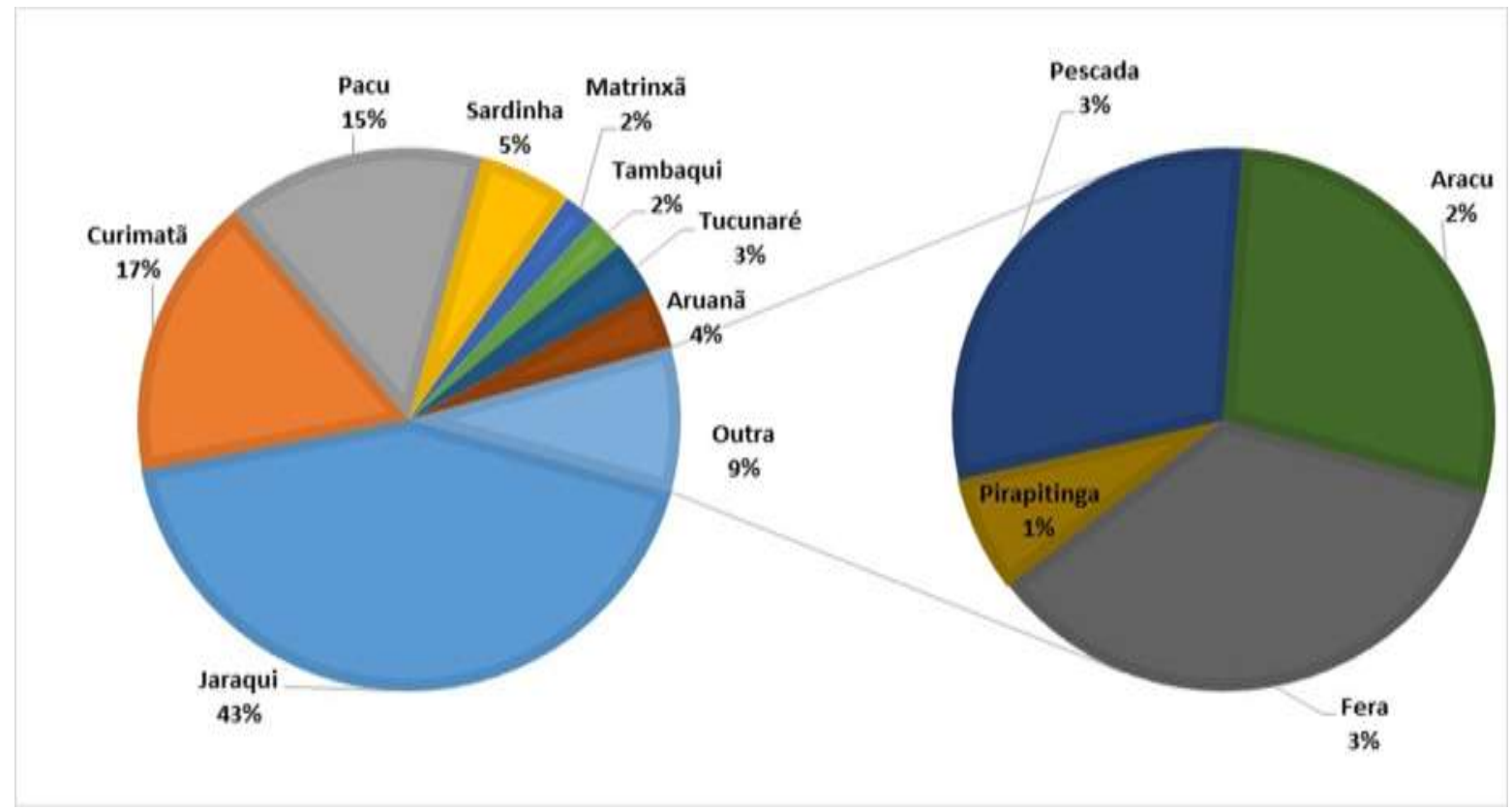

Figura 2: Percentual de captura das principais espécies desembarcadas no porto de Manaus/2012

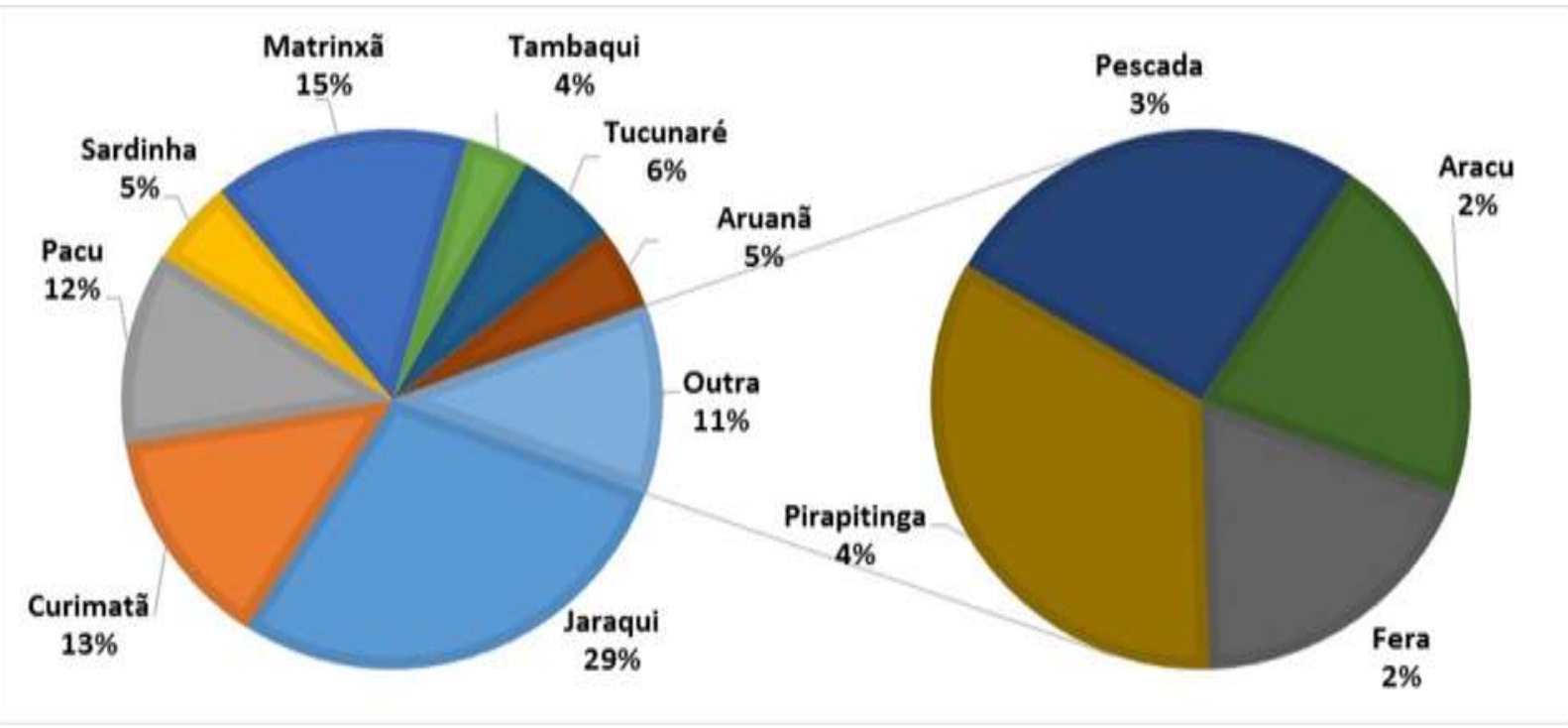

Figura 3: Percentual de captura das principais espécies desembarcadas no porto de Manaus/2013

A maioria das espécies citadas como capturadas nos dois anos testados pertencem ao grupo dos Characiformes, o mais importante para pesca fluvial da região amazônica (FARIA Jr. e BATISTA, 2019). No presente estudo, a espécie que apresentou maior número de citações em ambos os anos foi o Jaraqui, peixe apreciado na região e com baixo custo para o consumo. Concordando com o observado por Silva (2017) e por Guerreiro et al. (2020), que verificaram que está é a mais importante para pesca nessa região. O comércio do jaraqui gira em torno de duas espécies, o jaraqui de escama fina (Semaprochilodus taeniurus) e o jaraqui de escama grossa (Semaprochilodus insignis) (NETO e DIAS, 2015). Infelizmente os pescadores não fizeram distinção entre essas duas espécies para a Colônia de 
Pescadores, inviabilizando representá-las separadamente no atual estudo. Durante os anos testados essa espécie não esteve inclusa na lista do espécies protegidas pelo defeso, entrando somente para ela em 2015 (AMAZONAS, 2014), porém nos anos testados o seguro defeso não foi pago em tempo hábil para conter a pesca em todo o período necessário para abranger todo o período de defeso. 0 que é questionável uma vez que o jaraqui é considerado em estado de sobrepesca (BARTHEM et al., 2019). Esta espécie mais que dobrou de 2012 para 2013, tanto no total desembarcado como a produção específica em vários rios como o Negro, o Purus, o Coari. A pescaria pode não ter sido tão produtiva em 2012 devido a cheia extrema, devido os peixes estarem dispersos no ambiente aquático (MATOS et al. 2018). Porém a influência do nível do rio atípico sobre a produção só poderia ser testada se um maior número de anos tivesse sido utilizado na análise.

Em 2012, a segunda espécie com maior frequência no desembarque foi o Matrinxã (Brycon amazonicus), sendo que sua importância relativa no ano seguinte cai para a sétima posição. Entre 2001 e 2005 o IBAMA $(2003,2004 a, 2004 b, 2005,2007)$ colocou esse peixe entre o quarto e o sétimo lugar na composição de espécies capturadas da região, no presente estudo essa posição só se assemelha ao ano de 2013.

O curimatã destaca-se em ambos os anos, sendo que em 2013 ocupou o segundo lugar como o peixe de maior produção. Esta espécie tem grande importância nas pescarias artesanais e comercias da região, ocupando o primeiro lugar nos desembarques da Amazônia Central de 2007 a 2011 (FARIA Jr. e BATISTA, 2019), semelhante aos observado nos anos aqui testados que se seguiram ao desses autores (2012-2013).

A participação ainda grande do tambaqui nos desembarques não era esperada, uma vez que está espécie encontra-se sobre-explorada (OLIVEIRA et al. 2020, BANDEIRA, 2017). Provavelmente os grandes valores se devem ao transporte desta espécie oriunda da piscicultura, que segundo NÓBREGA et al. (2020), é frequente nesse mesmo Porto de Manaus para o mesmo período de tempo aqui analisado. 


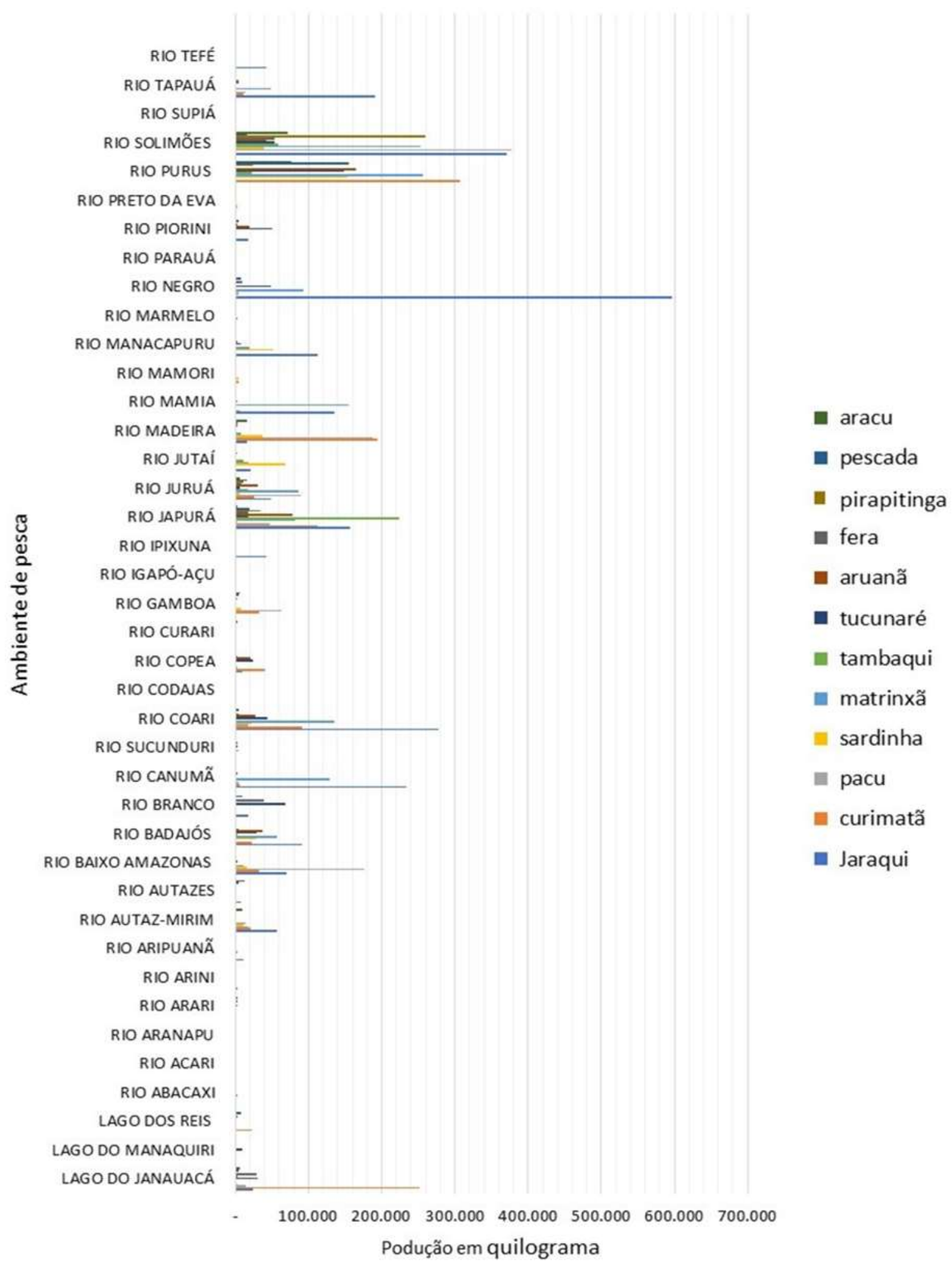

Figura 4: Relação entre o volume desembarcado por espécies e ambientes de pesca (lagos e rios) em 2012 


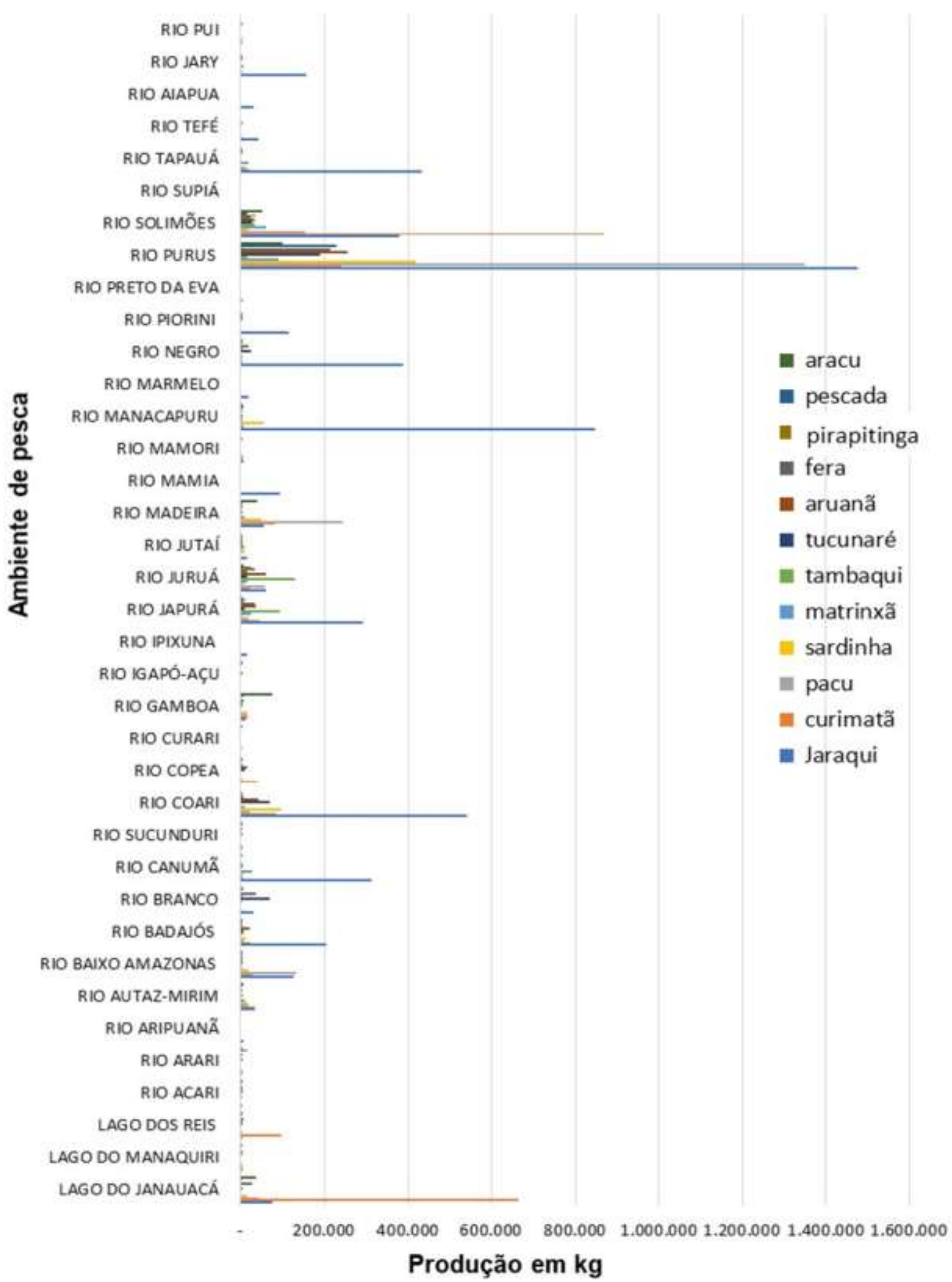

Figura 5: Relação entre o volume desembarcado por espécies e ambientes de pesca (lagos e rios) em 
Nas figuras 4 e 5, observamos que os principais ambientes de pesca da região são, os rios Purus e Solimões, tanto na quantidade quanto na diversidade de espécies, com destaque para a produção do jaraqui e pacu. Ambos são considerados os rios com maior produção da região (CORRÊA et al. 2018). Sendo grandes tributários de água branca estes possuem altos níveis de sais mineral em suspensão oriunda dos Andes, que se reflete na abundância em peixes, viabilizando a pesca comercial (CAD, 2017). Também são de água branca, como o Amazonas, Madeira, Purus, Juruá e Japurá e dessa forma é esperado que suas características proporcionam grande biomassa pesqueira (CORRÊA et al. 2018). De acordo com Lopes et al. (2017), o Purus é um rio que está sempre entre os maiores produtores da região, este mesmo autor relatou que nesse rio há destaque para a pesca dos Siluriformes (LOPES et al. 2016 e 2017). Porém estas espécies não se destacaram nesse rio, sendo a maior produção ocorrida de feras foi observa no Rio Branco e no Lago do Janaucá.

O rio Negro se destaca principalmente na produção do jaraqui. A importância deste ambiente fluvial para o jaraqui já foi observada por Junk (1983) e Guerreiro (2020), que relatam que estes migram por água pretas, pobres em nutrientes, para os rios de águas brancas para desovar e quando saem desses ambientes são capturas em grandes quantidades.

Os níveis de produção nos dois principais rios foram maiores no ano de 2013 do que em 2012. No estudo feito por Silva (2017), para produção pesqueira total de Manaus foi observado que esse este comportamento padrão para os desembarques envolvendo o total de espécies. Esta autora mencionou que provavelmente este fato foi influenciado pela cheia histórica de 2012 que ocorreu nesse trecho da bacia Amazônica. O efeito de grandes cheias e secas sobre a produção muitas vezes aparecem em anos seguintes, variando o tempo de resposta de acordo com a biologia das espécies e dinâmica da pescaria (CUSHING, 1981, LOPES et al 2017). Uma cheia extrema pode gerar maior produção em anos subsequentes pois podem favorecer o recrutamento biológico, aumento de zonas de refúgio, aumentar as fontes de alimento de origem alóctone e maior possibilidade de fuga de predadores devido a maior área de dispersão (DIAS et al. 2020., GUERREIRO, 2017).

\section{CONCLUSÃO}

As espécies capturadas foram provenientes de um total de 40 ambientes de pesca diferentes, englobando rios e lagos;

Os rios de água branca são os ambientes que mais contribuem para o desembarque na cidade de Manaus; 
O rio Purus e o Solimões são os principais rios relacionado com o desembarque pesqueiro na região, no que diz respeito a diversidade de espécies e volume de produção;

As espécies com maior quantidade desembarcada são o jaraqui, a matrinxã, o curimatã, o pacu, o tucunaré e o tambaqui. 


\section{REFERÊNCIAS}

AMAZONAS, 2014. IPAAM vai incluir Jaraqui, Surubim e Caparari no período de defeso, que inicia em novembro. Governo do Estado do Amazonas.http://www.amazonas.am.gov.br/2014/10/ipaam-vaiincluir-jaraqui-surubim-e-caparari-no-periodo-de-defeso-que-inicia-em-novembro/. 2014. Acessado em: 15/02/2021.

BANDEIRA, K. C. T. Efeitos dos eventos climáticos locais no recurso pesqueiro do tambaqui da Amazônia Central. 118 p. Tese (Doutorado em Ciências Pesqueiras nos Trópicos) - Universidade Federal do Amazonas, Manaus, 2017.

BARTHEM, R. B.; SILVA-JÚNIOR, U. L.; RASEIRA, M. B.; GOULDING, M.; VENTICINQUE, E. Bases para a conservação e o manejo dos estoques pesqueiros da Amazônia.105-148p. Museu Goeldi: 150 anos de ciência na Amazônia. Publisher: Editora MPEG, Belém.148p. 2019.

CAD, S. V. A produção pesqueira e o esforço da pesca no município de Manaus (Amazonas-Brasil): análise e proposta de melhorias para viabilizar a industrialização. 61 p. Dissertação (Mestrado em Engenharia de Produção) - Universidade Federal do Amazonas, Manaus, 2017.

CUSHING, D. H. Fisheries Biology: A study in population dynamics. 295p. 1981.

DIAS, G. K.S.; SOUZA, L. A.; FREITAS, C.E.C. Spatial and seasonal variation of peacock bass (Cichla spp.) fishery: an analysis of catches landed in Manaus, Amazonas State, Brazil. Boletim do Instituto de Pesca, [S.I.], v. 46, n. 3, dec. 2020.

FARIA-JÚNIOR, C. H.; BATISTA, V. S. Frota pesqueira comercial na Amazônia Central: composição, origem, espécies exploradas e mercado. Revista Agroecossistemas, v. 11, n. 1, p. 146-168, 2019.

GUERREIRO, A. I. C.; AMADIO, S. A., FABRÉ, N. N.; BATISTA, V.S. Exploring the effect of strong hydrological droughts and floods on populational parameters of Semaprochilodus insignis (Actinopterygii: Prochilodontidae) from the Central Amazonia. Environment, Development and Sustainability, 1-11. 2020.

GUERREIRO, A. I. C. Influência de extremos de cheia e de seca nos recursos capturados pela pesca comercial desembarcados no porto de Manaus (Amazonas, Brasil). Tese (Biologia de Água Doce e Pesca Interior) - Instituto Nacional de Pesquisas da Amazônia, Manaus, 2017. 111 p.

IBAMA. Estatística da pesca 2001. Brasília, Ibama, 124p. 2003.

IBAMA. Estatística da pesca 2002. Brasília, Ibama,129p. 2004a.

IBAMA. Estatística da pesca 2003. Brasília, Ibama,137p. 2004b.

IBAMA. Estatística da pesca 2004. Brasília, Ibama, 136p. 2005.

IBAMA. Estatística da pesca 2005. Available online at:

http://www.ibama.gov.br/rec_pesqueiros/download.php? id_download = 113 [Accessed: 07/03/2008]. 2007. 
JUNK, W. J. Aquatic habitats in Amazonia. Environmentalist, v. 3, n. 5, p. 24-34, 1983.

LEAL, W. M. M.; FREITAS, C. E. C.; SIQUEIRA-SOUZA, F. KDiversidade de peixes em lagos manejados em área de várzea Amazônica brasileira. Scientia Amaz, 7(1), 1-10. 2018.

LOPES, G. C.S.; CATARINO, M. F.; FREITAS, C. E.C A pesca de pequena escala na Bacia Amazônica: padrões gerais e diversidade pelos desembarques de cinco sub-bacias. Boletim do Instituto de Pesca, 42(4), 889-900. 2018.

LOPES, G. C.S.; DE SOUZA, L. A.; INOMATA, S. O. Modelagem das inter-relações entre a pesca e o regime fluvial no Rio Purus, AM. Revista Brasileira de Engenharia de Pesca, v. 10, n. 2, p. 94-112, 2017.

MATOS, O. F.; SANTOS LOPES, G. C.; FREITAS, C. E. C. (2018). A pesca comercial no baixo rio Solimões: uma análise dos desembarques de Manacapuru/AM. Biota Amazônia, 8(4), 1-8.

MONTENEGRO, L.S.; SOUZA, L.A. Produção pesqueira e sua relação com as oscilações do ciclo hidrológico e o crescimento demográfico da cidade de Manaus-Am. Scientia Amazônia, v. 5, n.2, 1423. 2016.

NETO, S. D.; DIAS, J. F. O. O uso da biodiversidade aquática no Brasil: uma avaliação com foco na pesca. Ministério do Meio Ambiente, Brasília, 2015.

NÓBREGA, T. C.; DE SOUZA, L. A.; BEZERRA, S. C.; LOBO, B. P. Variação temporal e origem do Tambaqui (Colossoma macropomum) desembarcado na feira da panair. Brazilian Journal of Development, 6(2), 9118-9132. 2020.

OLIVEIRA, C. M.; MARSHALL, B. G.; CARVALHO FREITAS, C. E.; NASCIMENTO, C. A. R.; SOUSA, R. G. C. A pesca ilegal do tambaqui nos Rios Negro, Solimões E Amazonas: uma análise dos efeitos da lei do defeso. Biota Amazônia, 10 (2), 1-5. 2020.

SILVA, S.N. 2017. Produção pesqueira e esforço de pesca do município de Manaus. Universidade Federal Do Amazonas. Faculdade De Ciências Agrárias. Departamento de Ciências Pesqueiras. Engenharia de Pesca. 2017. 30p. 


\section{Capítulo 2}

\section{PESCA EM UNIDADES DE CONSERVAÇÃO NA AMAZÔNIA CENTRAL}

Bruna Barbosa Alves

Vinícius Verona Carvalho Gonçalves
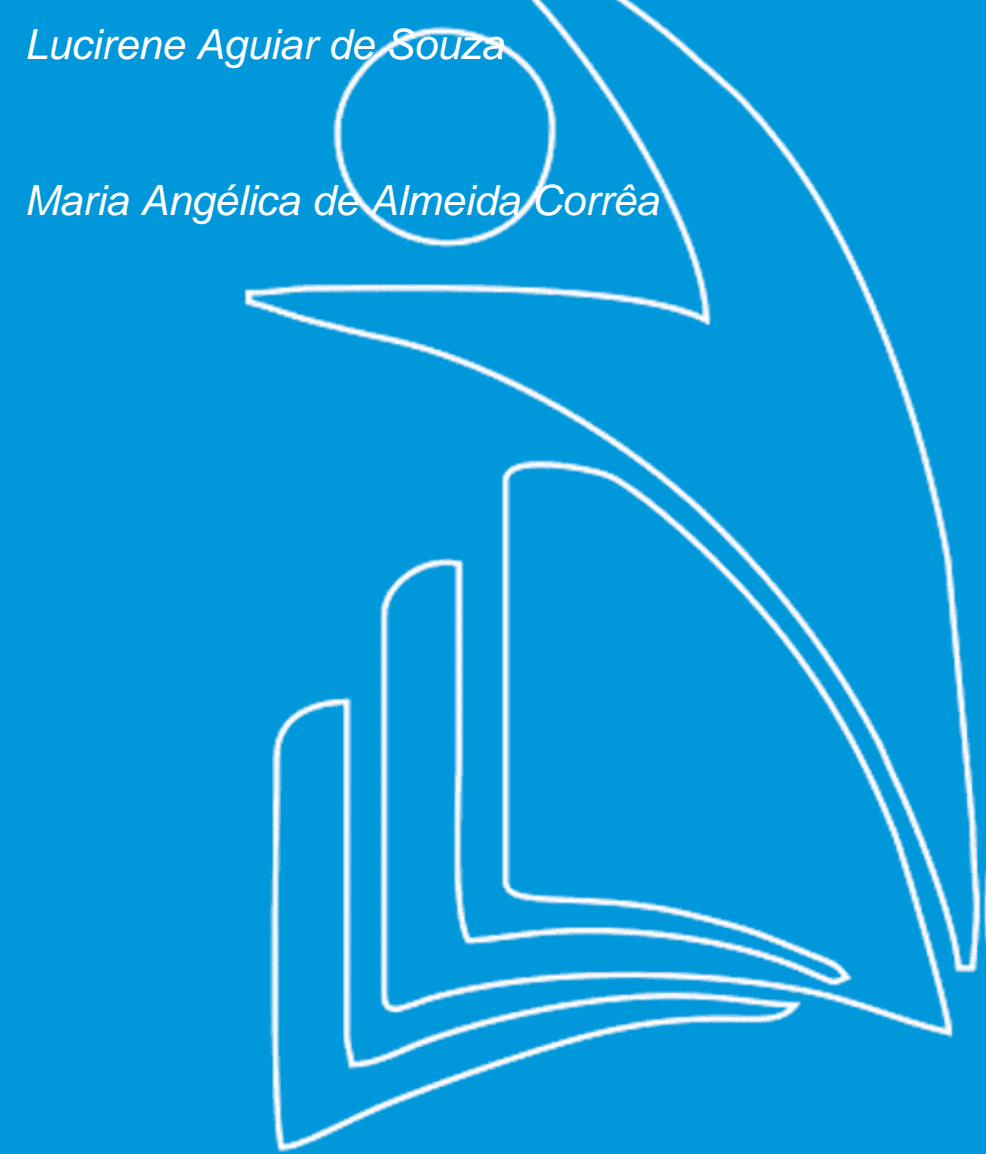

Graduanda em Engenharia de Pesca.

Faculdade de Ciências Agrárias,

Universidade Federal do Amazonas

Doutorando em Ciências Ambientais e

Sustentabilidade na Amazônia -

PPGCASA/UFAMT

Doutora em Biologia de Águr Doce e Pesca

Interior, P/ofesscra Associada da FCAVUFAM

Doutdra em qiências Pesqueivas nos

Trópicos, Prpfessora Adjunta da Faculdade

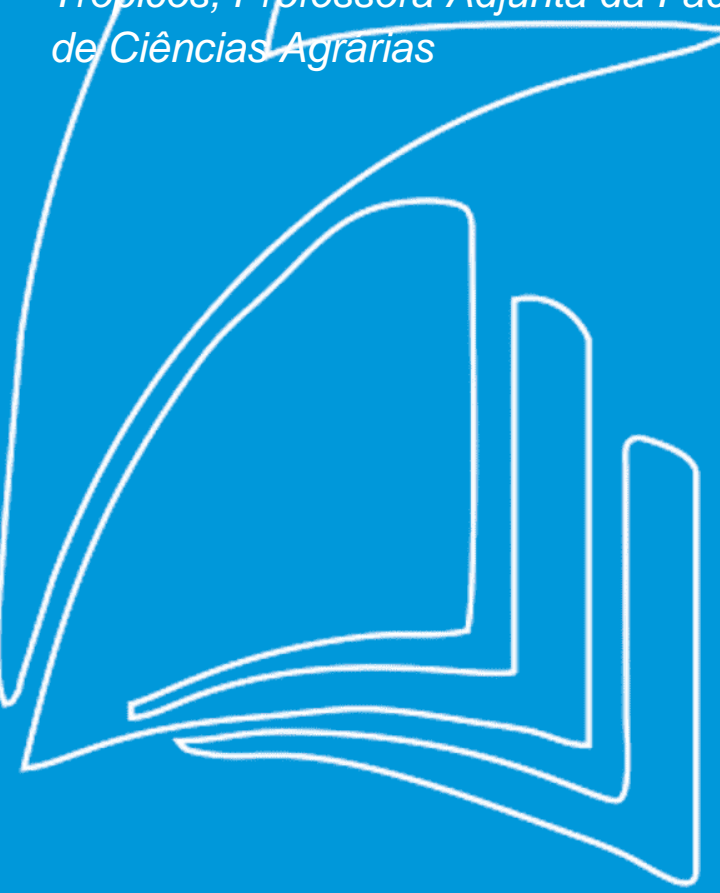


Resumo: As Unidades de Conservação (UCS) foram criadas com o objetivo de assegurar a manutenção dos recursos naturais a partir de modelos de governança e medidas de restrição de uso. Este trabalho objetivou descrever a pesca e a socioeconomia em duas categorias de UCs, e avaliar as espécies-alvo das pescarias comparativamente. As áreas de estudo são a Reserva de Desenvolvimento Sustentável Piagaçu Purus (RDS-PP) de uso parcial e controlado, e a Reserva Biológica Abufari (RBA) de restrição total de uso. A pesquisa foi realizada em fevereiro de 2019 e envolveu 284 famílias ribeirinhas. Independentemente do tipo de uso dos recursos, a pesca comercial é a principal atividade, declarada pelos entrevistados. O perfil dos pescadores possui características sociais comuns, sendo populações jovens em idade produtiva, com baixo nível de escolaridade, e vivendo há, aproximadamente, três décadas nas UCs. Não existe diferença entre as citações das espécies-alvo das pescarias realizadas nas UCs em virtude das restrições e da fiscalização a que são submetidas. Espécies de peixes de capturas proibidas foram citadas pelos pescadores da RBA.

Palavras-chave: Reserva de Desenvolvimento Sustentável; Reserva Biológica; Pescaria em reservas; Espécie-alvo. 


\section{INTRODUÇÃO}

No Brasil, em especial na Amazônia, a pesca de pequena escala é realizada para a subsistência e o abastecimento dos centros urbanos. Esta atividade econômica possui relevância no contexto social, econômico e cultural da região (McGRATH et al., 2004). Dentre os ambientes de pesca, os lagos são os ecossistemas mais produtivos e disputados por pescadores de várias modalidades (BATISTA et al., 2012). Ao longo do tempo, espécies comerciais como o pirarucu (Arapaima gigas) (CASTELLO et al. 2013) e o tambaqui (Colossoma macropomum) foram levadas a superexploração, e protagonizaram iniciativas políticas e modelos de gestão para a redução dos impactos.

Nas duas últimas décadas, o modelo que se destacou de forma eficiente na recuperação dos estoques foi o co-manejo ou co-gestão (CASTELLO et al. 2013). Ele tem como premissa o uso sustentável dos recursos naturais, baseado na tomada de decisões compartilhadas, envolvendo agentes comunitários, governamentais e não-governamentais, além da sociedade civil (McGRATH et al. 2015). De acordo com Freitas et al (2020), somente no estado do Amazonas existem 35 unidades de manejo, com a participação de 450 comunidades ribeirinhas. O modelo de co-manejo é homologado pelo Plano Nacional de Gerenciamento Costeiro (PNGC), e pelo Sistema Nacional de Unidades de Conservação (SNUC) (KALISKOSKI et al., 2009).

O Sistema Nacional de Unidades de Conservação (SNUC) foi instituído pela Lei 9.985 com o objetivo de criar, implementar e gerir Unidades de Conservação (UCs). Dentre as diversas modalidades destacamos as de Uso Integral (Reserva Biológica-REBIO), que objetivam a preservação da natureza admitindo apenas o seu uso indireto, ou seja, aqueles que não envolvam consumo, coleta ou danos aos recursos naturais; e, as de Uso Sustentável (Reserva de Desenvolvimento Sustentável-RDS), que visam compatibilizar a conservação da natureza com o uso sustentável dos seus recursos naturais, conciliando a presença humana nas áreas protegidas, permitindo o uso dos recursos, a partir de planos de manejo implementados (ALMEIDA, 2017; JERONYMO et al. 2020).

Em função da sua natureza, os sistemas de governança empregados nas UCs são distintos e vinculados a órgãos de controle ambiental sob diferentes esferas governamentais. No caso das RDSs, a governança se dá por meio da Secretaria do Meio Ambiente (SEMA), de esfera estadual, e nas REBIOs, a governança se dá por meio do Instituto Chico Mendes de Conservação da Biodiversidade (ICMBio), de esfera federal. Os diferentes modelos de gestão e governança pretendem controlar o uso e exploração dos recursos naturais e dos seus estoques, buscando a eficácia e a efetividade das suas medidas. Nesse contexto, este trabalho visa avaliar a pesca realizada nas duas modalidades de UCs na 
Amazônia, e identificar a preferência de espécies-alvo por parte dos pescadores, a partir das diferenças ou similaridades relatadas pelos entrevistados considerando os diferentes níveis de restrição formal e modelos de governança.

\section{MATERIAIS E MÉTODOS}

\section{ÁREA DE ESTUDO}

O estudo foi realizado na região da Amazônia Central, na sub-bacia do rio Purus. As áreas focais do estudo (Figura 1) são: a) Reserva de Desenvolvimento Sustentável Piagaçu-Purus (RDS-PP), criada em 05 de setembro de 2003, localizada no município de Beruri - AM com 1.008.167,00 hectares de área. Atualmente, a RDS desenvolve o manejo de pirarucu (Arapaima gigas) de acordo com a Normativa No. 34 de 18 de junho de 2004, do IBAMA. As comunidades que compõem a pesquisa na região são: São Sebastião do Itapuru, e Nossa Senhora do Rosário de Fátima ou Caua-Cuiuanã; e b) Reserva Biológica Abufari (RBA), criada em 20 de setembro de 1982, localizada no município de Tapauá - AM com 233.866,74 hectares de área. As comunidades participantes da pesquisa são: Tambaquizinho, Pupunha e Fazenda. A RBA abriga o mais significativo tabuleiro de desova de tartaruga-da-amazônia (Podocnemis expansa) do estado do Amazonas. Ambas as reservas estão situadas no Baixo Rio Purus.
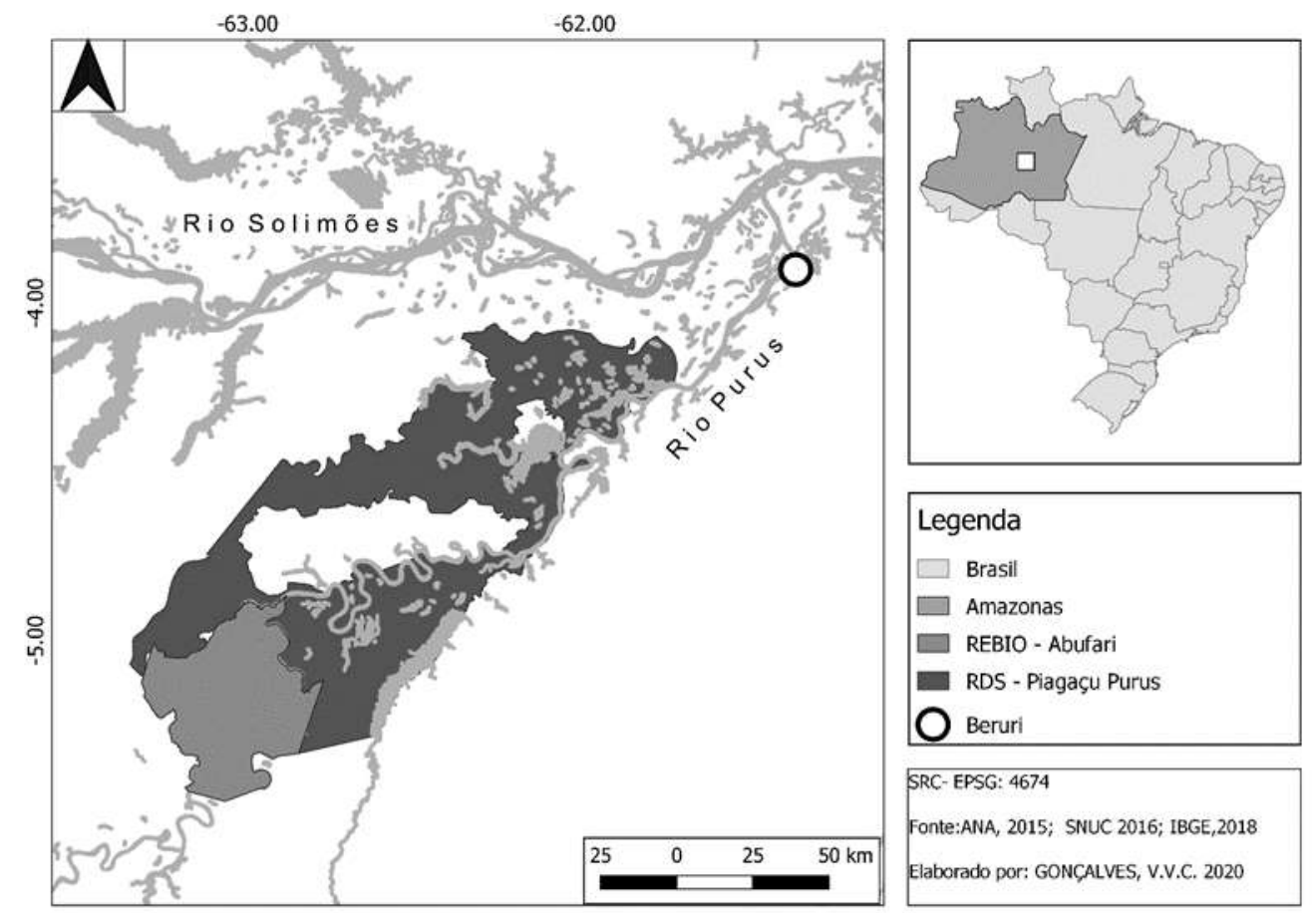

SRC- EPSG: 4674

Fonte:ANA, 2015; SNUC 2016; IBGE,2018

Elaborado por: GONÇALVES, V.V.C. 2020

Figura 1: Mapa de localização da RDS Piagaçu-Purus e da Rebio Abufari, AM 


\section{COLETA E ANÁLISE DE DADOS}

A coleta de dados ocorreu no período de 14 a 27 de fevereiro de 2019, envolvendo uma equipe de 4 pesquisadores treinados para este fim. Foram utilizados questionários semi-estruturados, que abordaram os aspectos socioeconômicos e da pesca na região. Os entrevistados foram as pessoas de referência, e as famílias unidades amostrais. Os dados foram inseridos em planilhas eletrônicas e submetidos à estatística descritiva. Para identificar a preferência de espécie-alvo das pescarias por parte dos pescadores foi utilizado o teste t-Student, nível de significância de 0,05\% (ZAR, 1996).

\section{RESULTADOS}

A pesquisa envolveu 284 famílias, sendo 201 da RDS-PP, e 83 da RBA. Estas famílias vivem em casas flutuantes ou palafitas nas áreas de várzea. A idade média dos entrevistados foi de 38 anos na RDSPP, e de 37 anos na RBA. Em relação à educação formal 53,84\% dos entrevistados da RDS-PP, e 44,45\% da RBA declararam possuir o nível do ensino fundamental. No entanto, os níveis de não alfabetizados correspondem a elevados percentuais de 21 a 29\% na RDS-PP e na RBA, respectivamente (Tabela 1).

Tabela 1. Dados socioeconômicos dos entrevistados da RDS Piagaçu Purus e da REBio Abufari

\begin{tabular}{l|c|c}
\hline Descrição & RDS-PP & RBA \\
\hline Quantidade de Famílias & 201 & 83 \\
\hline Níveis de educação & $15,62 \%$ & $13,00 \%$ \\
- Ensino Méd. Completo & $53,84 \%$ & $44,45 \%$ \\
- Ensino Fund. Completo & $21,40 \%$ & $29,01 \%$ \\
- Não alfabetizado & $38,4( \pm 12,6)$ & $37,8( \pm 12,5)$ \\
\hline Idade média dos & & \\
entrevistados & $26,09( \pm 17,9)$ & $31,5( \pm 17,6)$ \\
\hline Anos na comunidade &
\end{tabular}

A renda das famílias das UCs é proveniente dos múltiplos usos dos recursos das reservas: da pesca, do extrativismo vegetal e madeireiro, além da agricultura. A principal atividade produtiva para fins comerciais é a pesca, sendo desenvolvida por $67 \%$ das famílias da RDS-PP e $71 \%$ das famílias da RBA (Figura 2). A agricultura se destacou como a atividade complementar à renda da pesca, sendo desenvolvida por $48 \%$ das famílias da RDS-PP e $38 \%$ da RBA. São realizadas culturas rápidas, como o plantio de mandioca (Manihot esculenta), que posteriormente, transforma-se em farinha de mandioca 
para o consumo das famílias e para a comercialização do excedente. O extrativismo vegetal é desenvolvido na RBA (14\%) com a produção da castanha do Brasil (Bertholletia excelsa), enquanto as atividades de comércio, carpintaria e serviços gerais, denominadas como outros, ocorrem com maior incidência na RDS-PP (39\%), em termos comparativos (Figura 2).

Independentemente da modalidade da Unidade de Conservação, os entrevistados se autodeclararam pescadores de subsistência $(16,40 \%$ e $11,00 \%)$, pescando apenas para o autoconsumo, pescadores comerciais $(62,70 \%$ e $76,80 \%)$, e de ambas as modalidades (20,90\% e $12,20 \%)$, respectivamente nas RDS-PP e RBA.

Na RDS-PP, as pescarias comerciais são organizadas ao longo do ano, seguindo calendários de manejo por espécies, definidos por meio de acordos coletivos formais e informais. O manejo do pirarucu é baseado nas cotas de captura estabelecidas pelo IBAMA (órgão regulador) definidas a partir da contagem dos animais nos lagos realizada pelos manejadores (Acordo de Pesca). Além deste, o manejo do tambaqui e de espécies "miúdas" (de pequeno porte) é realizado a partir de um acordo interno (entre comunitários), com definições de períodos de pesca e cotas baseadas no peso total de captura. Neste estudo, o manejo do pirarucu é desenvolvido nas comunidades Itapuru e Caua-Cuianã, e o manejo do tambaqui e de espécies miúdas apenas na comunidade Itapuru.

Na RBA, a pesca para fins comerciais é proibida, sendo autorizada apenas a pescaria de subsistência para a garantia da segurança alimentar das famílias locais. Por se tratar de uma reserva biológica, a atividade é regularmente fiscalizada, gerando conflitos entre pescadores e fiscais ambientais, além de punições e apreensões de materiais de pesca e do pescado. Porém, a pescaria comercial foi autodeclarada por parte dos entrevistados.

As famílias ribeirinhas utilizam canoas nas suas diversas atividades produtivas, bem como para sua locomoção. As canoas são confeccionadas de madeira ou alumínio, movidas a remo ou por motores de propulsão de baixa potência, do tipo "rabeta" (5,5 e 6,5 HP de potência). As canoas motorizadas, com maior autonomia, são utilizadas por $68,26 \%$ e $70,73 \%$ das famílias da RDS-PP e RBA, respectivamente. 


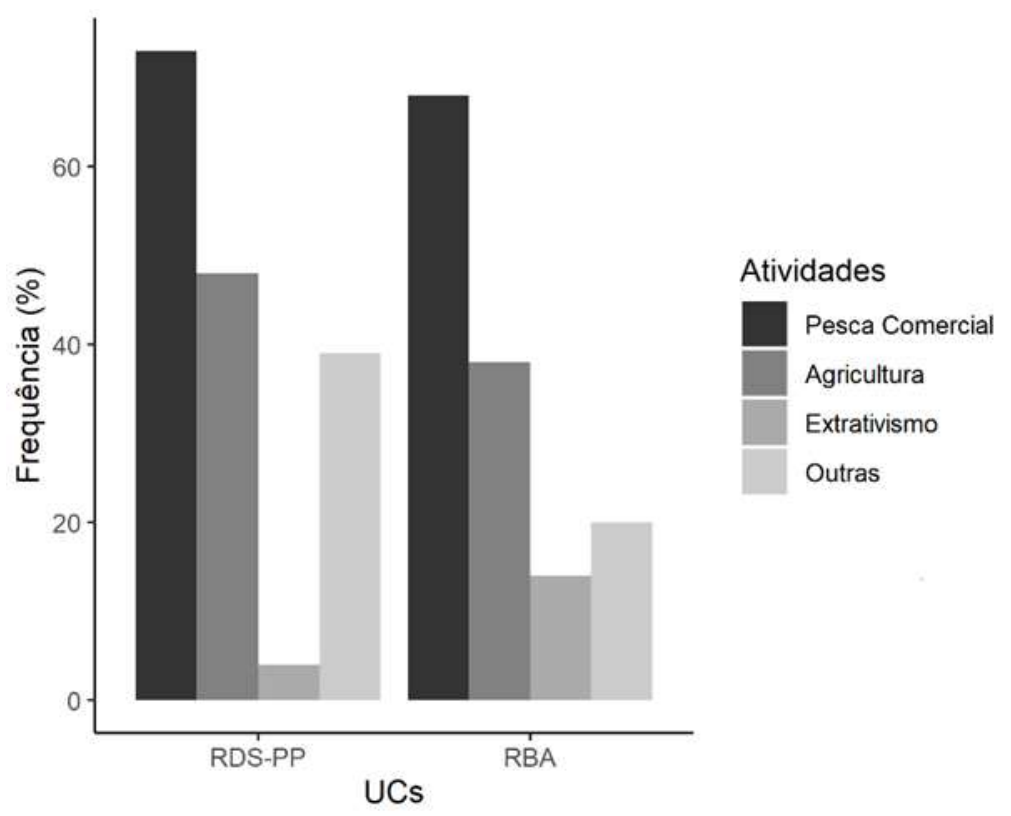

Figura 2: Atividades produtivas desenvolvidas pelas famílias da RDS-PP e RBA

Os apetrechos de pesca são especificados de acordo com o tipo de pescaria ou espécie-alvo, visando uma pescaria mais eficiente e produtiva conforme descrito na Tabela 4. Nas UCs pesquisadas foram registrados oito tipos de apetrechos de pesca, sendo a malhadeira a mais citada por $31 \%$ dos pescadores na RDS-PP, e por $43 \%$ dos pescadores na RBA (Tabela 2 ).

De acordo com os apetrechos de pesca utilizados e as espécies-alvo da pescaria, é possível indicar o modus operandi, que aponta para pescarias executadas individualmente. Destacamos as três espécies mais citadas pelos pescadores das por UCs preferenciais das pescarias que realizam, sendo: a aruanã (54\%), o tucunaré (45\%), e o tambaqui (42\%) na RDS-PP, e o tucunaré (54\%), o pacú (53\%), e a aruanã (46\%) na RBA (Tabela 3).

Em relação as citações das espécies-alvo, o teste t de Student confirmou que não existe diferença no número de citações de espécies ( $p=0,002$ ) (Figura 3). 
Tabela 2. Tipos de apetrechos com respectiva descrição, e o percentual de frequência de citação pelos pescadores, por reserva

\begin{tabular}{|c|c|c|c|c|}
\hline \multirow[t]{2}{*}{ Apetrecho } & \multirow[t]{2}{*}{ Descrição } & \multirow[t]{2}{*}{ Referência } & RDS-PP & RAB \\
\hline & & & Freq $\%$ & Freq $\%$ \\
\hline $\begin{array}{l}\text { Malhadeira } \\
\text { ou rede de } \\
\text { emalhar }\end{array}$ & $\begin{array}{l}\text { Rede com variação entre } 50-120 \\
\text { mm dos tamanhos entre nós } \\
\text { opostos, pode ser feita com nylon } \\
\text { com mono ou multifilamento, possui } \\
\text { boias na parte superior e chumbadas } \\
\text { na parte inferior. Arte passiva, } \\
\text { amplamente utilizada em ambientes } \\
\text { sem correnteza }\end{array}$ & $\begin{array}{l}\text { Coimbra et al, } \\
\text { 2017; Silva; } \\
\text { Braga, } 2016\end{array}$ & $31 \%$ & $43 \%$ \\
\hline Tramalha & $\begin{array}{l}\text { Malhadeiras fixas ou de deriva, } \\
\text { tamanho de malha de } 60-90 \text {, } \\
\text { coeficiente de entralhamento de } 0,58 \\
\text { em média }\end{array}$ & $\begin{array}{l}\text { Souza } \\
\text { Jr., } 2018\end{array}$ & $23 \%$ & $13 \%$ \\
\hline Caniço & $\begin{array}{l}\text { Anzol com linha, e caniço retirado da } \\
\text { mata }\end{array}$ & $\begin{array}{l}\text { Souza et al., } \\
2018\end{array}$ & $18 \%$ & $20 \%$ \\
\hline Espinhel & $\begin{array}{l}\text { Uma linha comprida, com as duas } \\
\text { pontas amarradas à margem, com } \\
\text { várias linhas menores com anzóis. }\end{array}$ & $\begin{array}{l}\text { Viana; Souza, } \\
2019\end{array}$ & $15 \%$ & $16 \%$ \\
\hline Arpão & $\begin{array}{l}\text { Arte de lançar composto de uma } \\
\text { haste de madeira com ponta metálica } \\
\text { afiada. Comum na pesca do pirarucu, } \\
\text { mas também é utilizado na pesca de } \\
\text { tambaquis grandes }\end{array}$ & Ferreira, 2017 & $5 \%$ & $4 \%$ \\
\hline $\begin{array}{l}\text { Arco e } \\
\text { flecha }\end{array}$ & $\begin{array}{l}\text { Arte de lançar composto de uma } \\
\text { haste de madeira com ponta metálica } \\
\text { afiada }\end{array}$ & $\begin{array}{l}\text { Souza et al, } \\
2018\end{array}$ & $5 \%$ & 0 \\
\hline Zagaia & $\begin{array}{l}\text { Arte de lança, com aproximadamente } \\
2 \text { a } 2,5 \text { m de comprimento e com } \\
\text { tridente fixado numa das } \\
\text { extremidades }\end{array}$ & $\begin{array}{l}\text { Cruz et al., } \\
2018\end{array}$ & $2 \%$ & $2 \%$ \\
\hline
\end{tabular}

Tabela 3. Percentual de citações de espécies-alvo das pescarias por UC

\begin{tabular}{cccc}
\hline Nome comum & Nome científico & RDS-PP & RBA \\
\hline Aruanã & Osteoglossum bicirrhosum & 111 & 37 \\
Tucunaré & Cichla sp & 92 & 44 \\
Tambaqui & Colossoma macropomum & 87 & 21 \\
Acará & Acarichthys heckellii & 65 & 20 \\
Jaraqui & Semaprochilodus sp & 44 & 7 \\
Pirarucu & Arapaima gigas & 41 & 17 \\
Pacú & Myleus rubripinnis & 36 & 43 \\
Surubim & Pseudoplatyatoma coruscans & 8 & 3 \\
Piranha & Pygocentrus nattereri & 3 & 7 \\
Sardinha & Triportheus elongatus & 6 & 9 \\
\hline
\end{tabular}




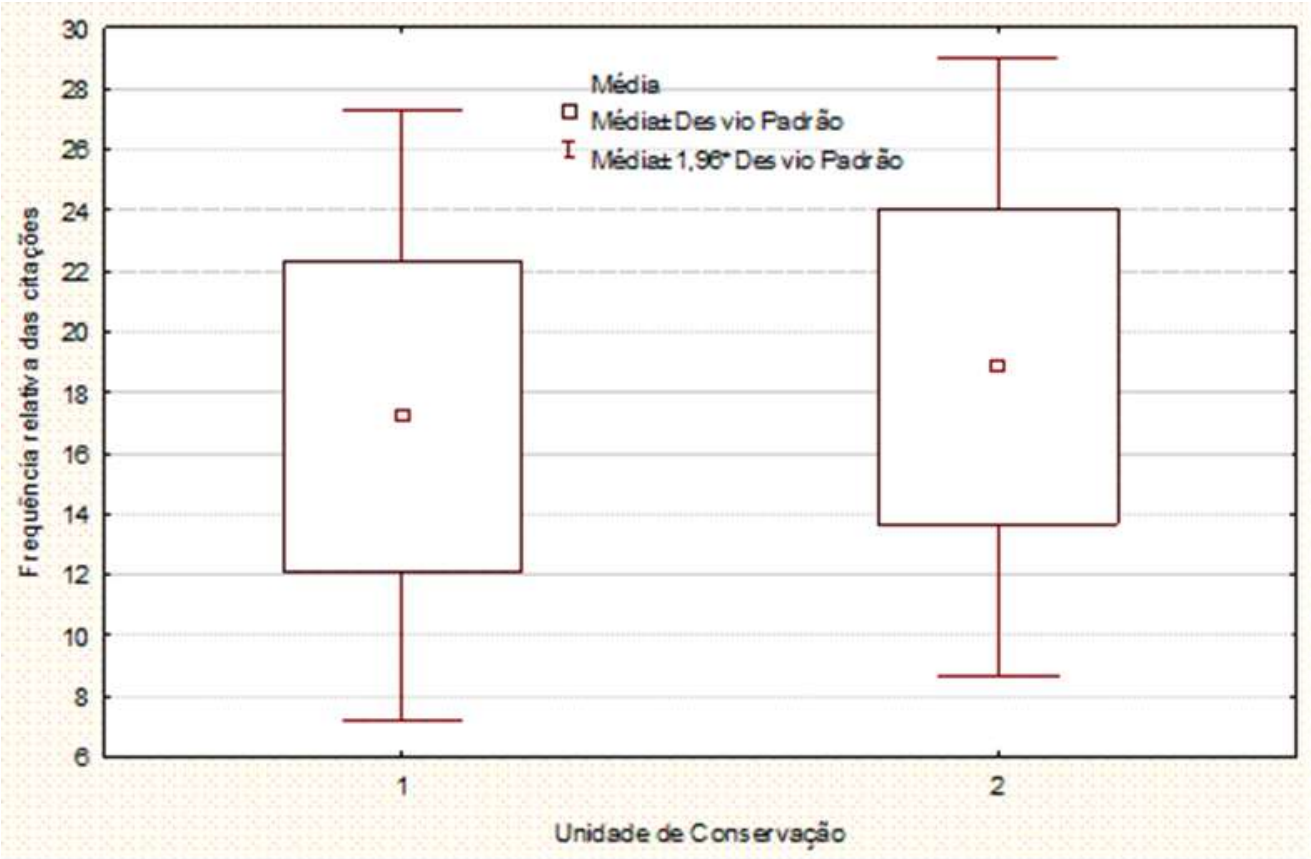

Figura 3. Comparação de média de citações entre a RDS Piagaçu Purus (1) e REBIO Abufari (2).

\section{DISCUSSÃO}

As pescarias em áreas protegidas na Amazônia têm sido pautadas por métodos de gestão participativa, por meio de acordos de pesca e do co-manejo (ALMEIDA, 2017). São premissas dessa forma de manejo a valorização dos conhecimentos ecológicos dos moradores e a participação dos usuários dos recursos no processo de gestão implementados (FERNANDEZ, 2019). Seus sistemas de governança possuem propósitos específicos de conservar e preservar, apoiados por diferentes esferas governamentais, sendo essa a principal distinção entre elas. A pesca na RDS-PP é realizada a partir de acordos de pesca, referendados pelos órgãos gestores, que conferem aos pescadores o direito de explorar, principalmente, as espécies de pirarucu e tambaqui, ambas de grande valor comercial. Enquanto a RBA tem suas pescarias desenvolvidas sob intensa fiscalização, restringindo-as a captura de espécies de baixo valor comercial e baixa produção. Desta forma, os pescadores da RDS-PP desenvolvem suas pescarias a partir da recuperação dos estoques de forma crescente e organizada, enquanto os da RBA resistem e restringem-se ao mínimo permitido, priorizando a segurança alimentar, em função da preservação dos estoques.

A análise comparativa das citações das espécies-alvo pelos pescadores de ambas as UCs, não houve diferença entre as médias, mostrando que o padrão de exploração é igual tanto na RDS-PP quanto na RBA. Este resultado indica que apesar das restrições legais de uso dos recursos impostos às reservas as espécies-alvo são as mesmas, salvo os casos omissão por parte de grupos de pescadores da RBA, 
para evitar represálias. As mesmas espécies citadas são abundantes nos lagos de várzea e igapós na região estudada, ambientes preferenciais da pesca na Amazônia (VERBA et al., 2018).

A prática comercial dos pescadores é declarada nas UCs, independentemente da proibição de pescar para este fim na RBA. Pode-se então considerar que os pescadores não estão obedecendo as regras da reserva, ou estão indo pescar fora dela, o que pode ser pouco provável se considerar suas pequenas embarcações (canoas) e o baixo poder de autonomia delas. Uma alternativa pode ser a de estarem participando de campanhas de pesca de fora da reserva, para se dirigirem a pesqueiros mais distantes.

Os Characiformes citados como mais capturados nas UCs são comuns aos estudos de desembarque pesqueiro na bacia Amazônica, com ocorrência nos principais portos de desembarque ao longo da calha Amazonas-Solimões (ZACARDI et al. 2017; ALCÂNTARA et al. 2015; ISAAC et al. 2015), com exceção do tambaqui, que atualmente, tem grande participação das pisciculturas (NÓBREGA et al. 2020). O grande número de citações do aruanã e do tucunaré pelos pescadores da RDS-PP, pode estar associado ao manejo dos peixes miúdos com maior valor comercial comparado às demais espécies da lista. Na RBA, as mesmas espécies podem estar sendo alvo de capturadas pela abundância nos lagos e igapós, mais preservados. A lista das 10 espécies mais citadas pelos pescadores das UCs é comum. Apesar de menor incidência de citações pela RBA, as regras e fiscalização da reserva não interferem na escolha das espécies-alvo.

Os principais apetrechos utilizados pelos pescadores são as redes de emalhar, como a malhadeira e a tramalha, já observado por Souza Jr. (2018) para o Município de Manacapuru-AM, e por Faria Júnior; Batista (2019) na Amazonia Central. Os apetrechos de pesca estão relacionados ao comportamento das espécies conhecido pelo pescador de forma empírica (SOUZA et al. 2018). A malhadeira é a mais utilizada nas pescarias artesanais ao longo de todo o ano, em função da sua versatilidade para a captura de múltiplas espécies (CORRÊA et al. 2012). Além disso, a facilidade de manuseio e a possibilidade de desenvolver outras atividades enquanto ela está armada, favorece o seu uso frequente (FREITAS; RIVAS, 2006).

O perfil dos entrevistados da UCs é semelhante ao do estudo de Petrere Jr. et al. (2006), indicando uma população jovem de pescadores na Amazônia. São indivíduos em idade produtiva, o que em termos econômicos, pode ser um indicativo para o desenvolvimento futuro de políticas públicas. Contudo, a baixa escolaridade é um problema recorrente neste tipo de comunidade (BASTOS, 2009), tendo em vista à distância até os centros urbanos, dificultando o acesso à escola em nível médio. 
Entre as UCs a formação escolar dos entrevistados é similar, inclusive no nível de não alfabetizados, com indicadores de 21 a 29\% dos entrevistados. Em 2018, a taxa de analfabetos no Brasil era de 6,8\%, e em 2019, na região Norte era de 7,6\% (IBGE, 2019), percentuais de 3 a 4 vezes menores do que os encontrados na região do estudo. Outros aspectos devem ser considerados em estudos sobre escolaridade na região é a incompatibilidade de horário entre o trabalho e o tempo destinado ao estudo (BORCEM et al., 2011). Além disso, as atividades produtivas desenvolvidas no local, exigem baixa qualificação e educação formal, como a pesca e a agricultura, contribuindo para uma menor importância da educação na vida dessas populações (BORCEM et al., 2011).

Nas UCs há restrições no uso dos recursos, mas a pesca é a principal atividade para manutenção da vida (BORCEM et al., 2011; HORA; MOREIRA, 2019). A pluralidade das atividades produtivas e suas combinações, são consideradas estratégicas para suprir as necessidades básicas dos ribeirinhos, tanto para subsistência quanto para a geração de renda (NEGRÃO, 2019). A agricultura ocorre no período da seca, época propícia para o plantio nas áreas de várzea, podendo gerar uma diminuição da pesca pelo deslocamento dessa mão-de-obra (ABADIAS, 2019; SANTOS; COSTA., 2020). Além disso, existem as atividades de caça, extrativismo vegetal, comércio, serviços gerais e públicos, em menor proporção e fins.

\section{CONCLUSÃO}

A pesca comercial é a principal atividade comercial das UCs.

As espécies-alvo das pescarias das UCs são comuns, independentemente das restrições impostas pelas modalidades de gestão.

\section{AGRADECIMENTOS}

Ao CNPq, A FAPEAM, ao PELD-DIVA, aos comunitários da RDS Piagaçu Purus e REBIO Abufari, gestores das UCs, à SEMA e ao ICMBIO, pelo apoio à pesquisa. 


\section{REFERÊNCIAS}

ABADIAS, K. S. Conservação da agrobiodiversidade por agricultores familiares em áreas de várzea na Amazônia Central. Dissertação (Mestrado em Agronomia Tropical) - Universidade Federal do Amazonas, Manaus, 88p. 2019.

ALCANTARA, N. C.; GONÇALVES, G. S.; BRAGA, T. M. P.; SANTOS, S. M.; ARAUJO, R. L.; PANTOJA-LIMA, J.; ARIDE, P. H. R.; OLIVEIRA, A. T. Avaliação do desembarque pesqueiro (2009-2010) no município de Juruá, Amazonas, Brasil. Biota Amazônia, v. 5, n.1, p. 37-42. 2015.

ALMEIDA, N. J. R. Etnoconhecimento em unidade de conservação na Amazônia brasileira. Confronteiras, v. 1, n. 1, 2017.

BASTOS, G. C. Análise financeira das pescarias de pequena escala no município de Florianópolis (SC). Dissertação de Mestrado. USP. São Carlos. Brasil. 166 p. 2009.

BATISTA, V. S.; ISSAC, V. J. Peixes e Pesca no Solimões-Amazonas: Uma Avaliação Integrada. Instituto Brasileiro do Meio Ambiente e dos Recursos Naturais Renováveis, Brasília: 276 pp. 2012.

BORCEM, E. R.; FURTADO JÚNIOR, I.; ALMEIDA, I. C.; PALHETA, M. K. S.; PINTO, I. A. A atividade pesqueira no município de Marapanim-Pará, Brasil. Revista de Ciências Agrárias, 54 (3), 189-201. 2011.

CASTELLO, L.; MCGRATH, D. G.; HESS, L. L.; COE, M. T.; LefEBVRE, P. A., PETRY, P.; MACEDO, M. N.; RENO, V. F.; ARANTES, C. C. The vulnerability of Amazon freshwater ecosystems. Conservation Letters, p. 1-13. 2013.

COIMBRA, A. B.; TERRA, A. K.; DE SOUZA MAZUREK, R. R., DOS SANTOS PEREIRA, H., BELTRÃO, H., SOUSA, R. G. C. Atividade pesqueira dos índiosMura no Lago Ayapuá, Baixo Rio Purus, Amazonas, Brasil. Desafios, 4(1), 115-129. 2017.

CORRÊA, A.A; KAHN, J.R; FREITAS, C. E.C. A pesca no município de Coari estado do Amazonas, Brasil. Revista Brasileira de Engenharia de Pesca. v.6, n.2, p.1-7. 2012.

CORRÊA, M. A. A. Subsídios ao ordenamento de pesca de pequena escala na Amazônia: um enfoque econômico. Tese, CIPET-UFAM. Manaus, 130 p. 2017.

CRUZ, R. É. A., ISAAC, V. J., PAES, E. T. A pesca da dourada Brachyplatystoma rousseauxii (Castelnau, 1855) na região do baixo Amazonas, Brasil. Boletim do Instituto de Pesca, 43(4), 474-486. 2018.

FARIA JR, C.H.; BATISTA, V.S. Frota pesqueira comercial na Amazônia Central: composição, origem, espécies exploradas e mercado. Revista Agroecossistemas, 11(1), 146-168. 2019.

FERNANDEZ, T. D. A. C. Saberes e práticas locais no manejo comunitário da pesca artesanal no Brasil: contribuições da pesquisa-ação e do enfoque adaptativo para uma política ambiental justa e sustentável. Revista Desenvolvimento Social, 10(3), 85-101. 2019.

FERREIRA, R. R. O vento e o arpão ou as regras do jogo: A pesca artesanal do pirarucu na ilha de São Miguel, Santarém-Pa. Revista Ciências Da Sociedade, 1.2: 166-172. 2017. 
FREITAS, C. E. C.; RIVAS, A. A. F. A pesca e os recursos pesqueiros na Amazônia Ocidental. Ciência e Cultura, 58 (3), 30-32. 2006.

FREITAS, C.T; LOPES, P.F.M; CAMPOS-SILVA, J.V; NOBLE, M.N; DYBALL, R; PERES, C.A. Co-management of culturally important species: A tool to promote biodiversity conservation and human well-being. People and Nature, 2: 61-81. 2020.

HORA, N.; MOREIRA, Á. Importância comercial e de subsistência da pesca para comunidades da várzea do Baixo Amazonas. Enciclopédia Biosfera, 16.30. 2019.

IBGE. Pesquisa Nacional por Amostras de Domicílios. Diretoria de Pesquisa, Coordenação de Trabalho e Rendimento, Contíbua, 2012-2019.

ISAAC, V. J.; ALMEIDA, M. C.; GIARRIZZO, T.; DEUS, C. P.; VALE, R.; KLEIN, G.; BEGOSSI, A. Food consumption as an indicator of the conservation of natural resources in riverine communities of the Brazilian Amazon. Anais da Academia Brasileira de Ciências, v. 87, n. 4, p. 2229-2242, 2015.

JERONYMO, C. A. L.; DA SILVA, E. R.; FONSECA, K. T. Uma análise da dimensão" tipo de governança" em Unidades de Conservação da Natureza no Brasil. Novos Cadernos NAEA, v. 23, n. 3, 2020.

KALISKOSKI, D; SEIXAS, C. S.; ALMUDI, T. Gestão compartilhada e comunitária da pesca no Brasil: avanços e desafios. Ambiente \& Sociedade, 12(1), 151-172, 2009.

MCGRATH, D. G.; NEPSTAD, D.; AZEVEDO- RAMOS, C.; LIMA, E.; PEREIRA, C.; MERRY, F. Managing the Amazon Timber Industry. Conservation Biology (Online), Estados Unidos, v. 18, n.2, p. 575-577, 2004.

MCGRATH, D.G; CASTELLO, L; ALMEIDA, O.T; ESTUPINAN, G.M.B. Market Formalization, Governance, and the Integration of Community Fisheries in the Brazilian Amazon. Society \& Natural Resources, 28:513-529. 2015.

NEGRAO, M. P. Renda e atividades econômicas na Amazônia. In: François-Michel Le Tourneau; Otávio do Canto. Amazônias brasileiras, Situações locais e evoluções, vol. 2 Análises temáticas, NUMA/UFPa, pp.65-106, 2019.

NÓBREGA, T. C., SOUZA, L. A., BEZERRA, S. C. \& LOBO, B. P. Variação temporal e origem do Tambaqui (Colossoma macropomum) desembarcado na feira da Panair. Brazilian Journal of Development, 6(2), 9118-9132. 2020.

PETRERE JR, M.; WALTER, T.; MINTE-VERA, C. V. Income evaluation of smallscale fishers in two Brazilian urban reservoirs: Represa Billings (SP) and Lago Paranoá (DF). Brazilian Journal of Biology, v.66, p.817828. 2006.

SANTOS, D. I. P.; DA COSTA, F. S. Adaptabilidade ribeirinha diante das variações de seca e cheia do Lago Jenipapo (Manicoré/Am). Terceira Margem Amazônia, 6-5p. 2020

SILVA, J T; BRAGA, T. M. P. Caracterização da Pesca na comunidade de Surucuá (Resex Tapajós Arapiuns). Biota Amazônia, 6(3), 55-62. 2016. 
SOUZA JR, M. T. Redes de pesca empregadas pelos pescadores comerciais em uma área de intensa atividade pesqueira do Baixo Amazonas: caracterização, técnicas e eficiência de captura. Dissertação CIPET-UFAM, Manaus, 2018.67p. 2018.

SOUZA, L. A.; FREITAS, C E. F.; SOUZA, R. C. Relação entre guildas de peixes, ambientes e petrechos de pesca baseado no conhecimento tradicional de pescadores da Amazônia Central. Boletim do Instituto de Pesca, 41.3: 633-644. 2018.

VERBA, J. T.; BORGES, M.L.O, SILVA, M. N.F, PINTO, L.C; RABELLO NETO, J. G. Mice on menu: opportunistic feeding behaviour of the Amazonian silver arowana Osteoglossum bicirrhosum. Journal of fish biology, 93(1), 132-133. 2018.

VIANA, J. S.; SOUZA, R. F. C. A pesca artesanal com espinhel de fundo na Plataforma Continental Amazônica. Arquivo de Ciências do Mar. Fortaleza, v. 52, n. 1, p. 21-33, 2019.

ZACARDI, D. M.; SARAIVA, M. L.; VAZ, E. M. Caracterização da pesca artesanal praticada nos lagos Mapiri e Papucu às margens do rio Tapajós, Santarém, Pará. Revista Brasileira Engenharia Pesca, v.10, n. 1, p. 32- 44. 2017.

ZAR, J.H. Biostatistical analysis. 4aed. New Jersey, Prentice-Hall, Inc., 663p. 1999. 


\section{Capítulo 3}

\section{doi $10.37423 / 210904736$}

\section{VARIAÇÃO ESPACIAL E SAZONAL DA PESCA DE MATRINXÃ (BRYCON SPP.) DESEMBARCADO EM MANAUS-AM}

Glenda Katherine de Souza Dias

Lucirene Aguiar de Souza

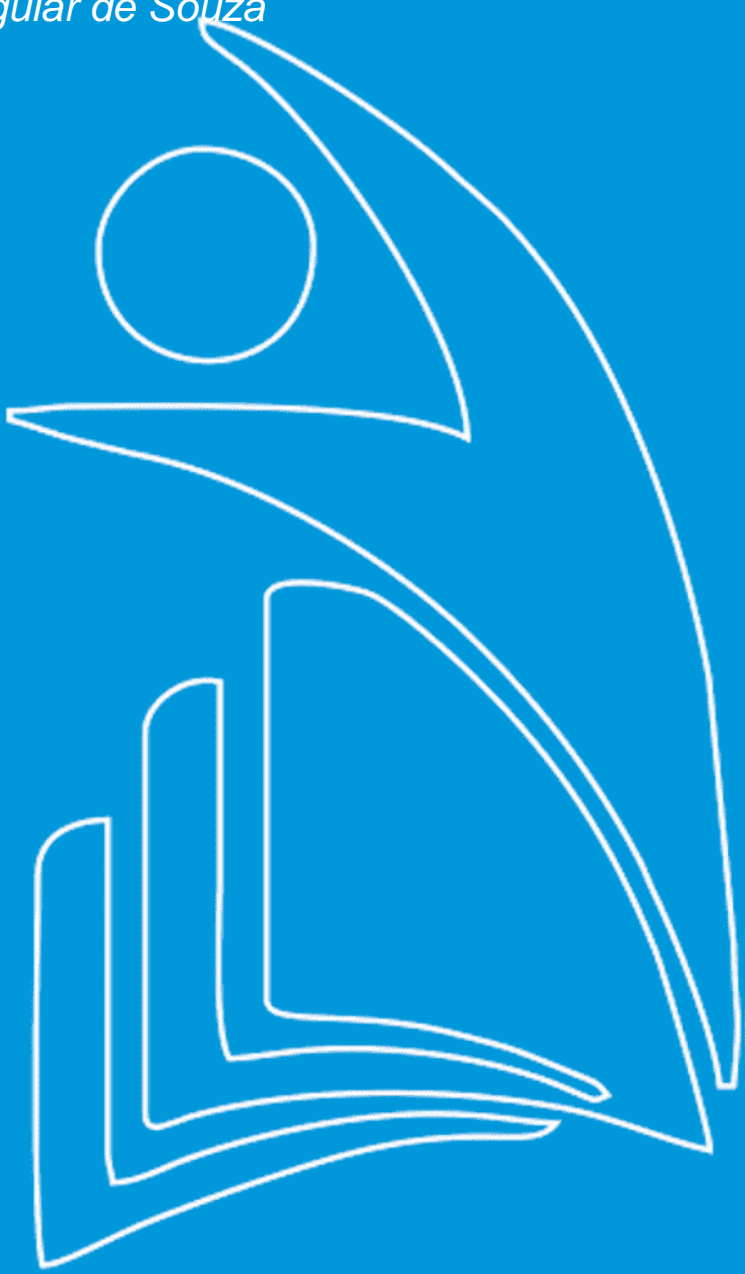

Mestranda em Biologia de Água Doce e

Pesca Interior. Instituto Nacional de

Pesquisas da Amazônia

Doutora em Biologia de Água Doce e Pesca Interior, Professora Asseciada da FCAVUFAM

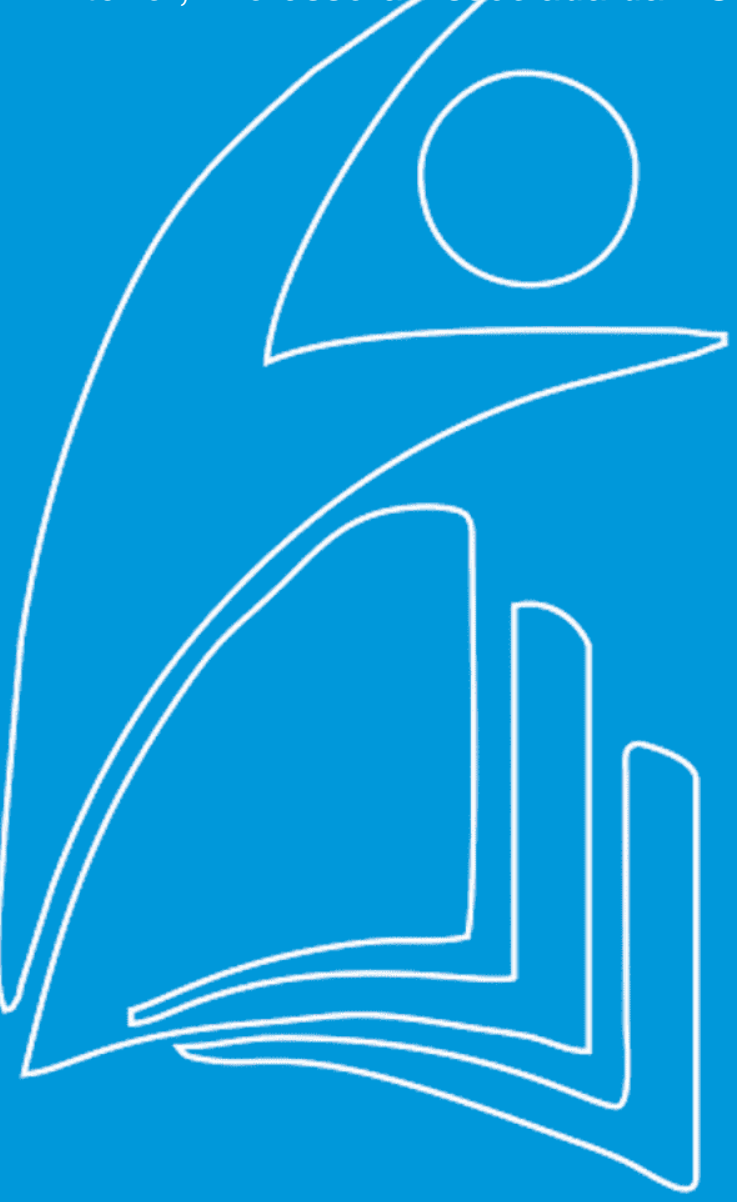


Resumo: A matrinxã (Brycon spp.) é uma espécie importante para pesca comercial e possui alto valor no mercado. O objetivo desta pesquisa foi avaliar a variação espacial e sazonal da pesca de matrinxã, a partir do desembarque no Porto da Panair-Manaus. Os dados são secundários e fornecidos pela Colônia de Pescadores Z12 e a cota do nível do rio foi fornecida pela Agência Nacional de Águas (ANA). Todos os dados são referentes aos anos de 2012 e 2013, e foram tabelados em planilhas eletrônicas. A CPUE obteve-se pela divisão entre a produção mensal e o número de barcos que realizaram o desembarque. A produção dos rios foi analisada pela ANOVA e o teste LSD Fisher mostrou quais diferenciavam entre si. $O$ teste $t$ foi utilizado para demonstrar diferenças na produção entre águas pretas e brancas. A produção $(\mathrm{kg})$ desembarcada da matrinxã de acordo com o regime fluvial $(\mathrm{m})$ do rio Negro, revelou picos de produção no mês de abril 564.900 kg desembarcadas em 2012, e em maio com $84.900 \mathrm{~kg}$ desembarcadas no ano de 2013. A CPUE no ano de 2012 e 2013 alcançou seu máximo no mês de abril, com 4.247,37 ( $\mathrm{kg} / \mathrm{n}^{\circ}$ barcos) e 2.493,94 ( $\mathrm{kg} / \mathrm{n}^{\circ}$ barcos), respectivamente. A Anova mostrou que no ano de 2012, houve diferença $(p<0,001)$ na produção $(\mathrm{kg})$ desembarcada da matrinxã segundo o rio de origem, sendo a maior média de produção correspondente ao Rio Jari. No ano de 2013 a ANOVA revelou que não houve diferença estatística $(p=0,07)$ na produção média entre rios. A análise da produção $(\mathrm{kg})$ desembarcada de acordo com o tipo de água revelou que em ambos os anos analisados a produção nos dois tipos de ambientes foi estatisticamente igual ( $p>0,05)$.

Palavras-chave: Tipo de água; Ciclo hidrológico; Produção pesqueira. 


\section{INTRODUÇÃO}

Bacia Amazônica possuem águas superficiais de diferentes características físico-químicas, que interagem e alagam grandes planícies ao longo do seu curso (SORRIBAS et al. 2017). Estas podem ser classificadas em: branca, como o Rio Solimões que tem origem nos Andes e é rico em nutrientes; preta, como o Rio Negro que é considerado pobre em nutrientes; e a clara, que são transparentes e tem baixa quantidade de sedimentos, tudo isso com base no $\mathrm{pH}$, condutividade, substância inorgânicas e orgânicas transparência, tendo essas características influência na produtividade dos rios (FASSONIANDRADE e PAIVA, 2017).

O ciclo hidrológico dos rios da região apresentam quatro fases: enchente, sendo a fase mais longa que ocorre entre dezembro e abril, caracterizada pela migração das espécies para desova; cheia, é a fase mais curta e acontece de maio a junho, durante esse período os juvenis estão em crescimento e se alimentam do que é fornecido pela floresta inundada; vazante, tem período de média duração e ocorre de julho a setembro, identifica-se como a época em que os peixes saem da floresta alagada; e seca, também fase curta, ocorrendo de outubro a novembro, aqui os peixes são mais vulneráveis à captura já que estão confinados pelo baixo volume de água (SILVA e NODA, 2016).

Dentre os principais grupos de peixes da região tem destaque os da ordem Characiformes, tanto na sua abundância no ambiente quanto na pesca. Dentre elas se destaca a matrinxã (Brycon amazonicus) que ocorre principalmente na Amazônia Central, costuma habitar as áreas alagadas e utiliza o canal do rio para sua migração (BENACON et al., 2015). A espécie tem hábito alimentar de caráter onívoro, no qual os juvenis preferem insetos e restos de animais ou plantas, já os adultos as frutas e sementes (MATTOS et al., 2018). Realizam uma migração trófica pela floresta alagada durante a enchente, época de reprodução e possui desova total (NAKAUTH et al, 2016).

A matrinxã se destaca comercialmente, estando entre as principais espécies mais capturadas (NASCIMENTO et al. 2020). Apesar de estudos realizados sobre o desembarque mostrarem que variam as quantidades capturadas por espécie, a matrinxã sempre compõe uma boa parte dessas capturas, como é exemplificado por Gonzales et al (2019) e Ayala et al (2018). Além da grande relevância para a pesca comercial e de subsistência, se destaca também na aquicultura regional (NASCIMENTO et al. 2020).

Sabendo da importância da matrinxã (Brycon spp.) para a região, assim como, que o ciclo hidrológico tem influência na captura dos peixes e que o tipo de água também tem relação com a produtividade 
dos estoques pesqueiros, essa pesquisa teve como objetivo avaliar a variação do desembarque desta espécie na Feira da Panair, porto oficial de comercialização primaria do pescado que abastece Manaus, relacionando-o com a variação do nível do rio, o tipo de água e o rio de origem que a mesma foi capturada, em anos subsequentes.

\section{MATERIAL E MÉTODOS}

\section{ÁREA DE ESTUDO}

A área de estudo compreende aos rios e lagos da Amazônia Central, seno o ponto de coleta o Porto da Panair, na cidade de Manaus - Amazonas (3 8'51.13"S 060 0'38.01"O) (Figura 1).

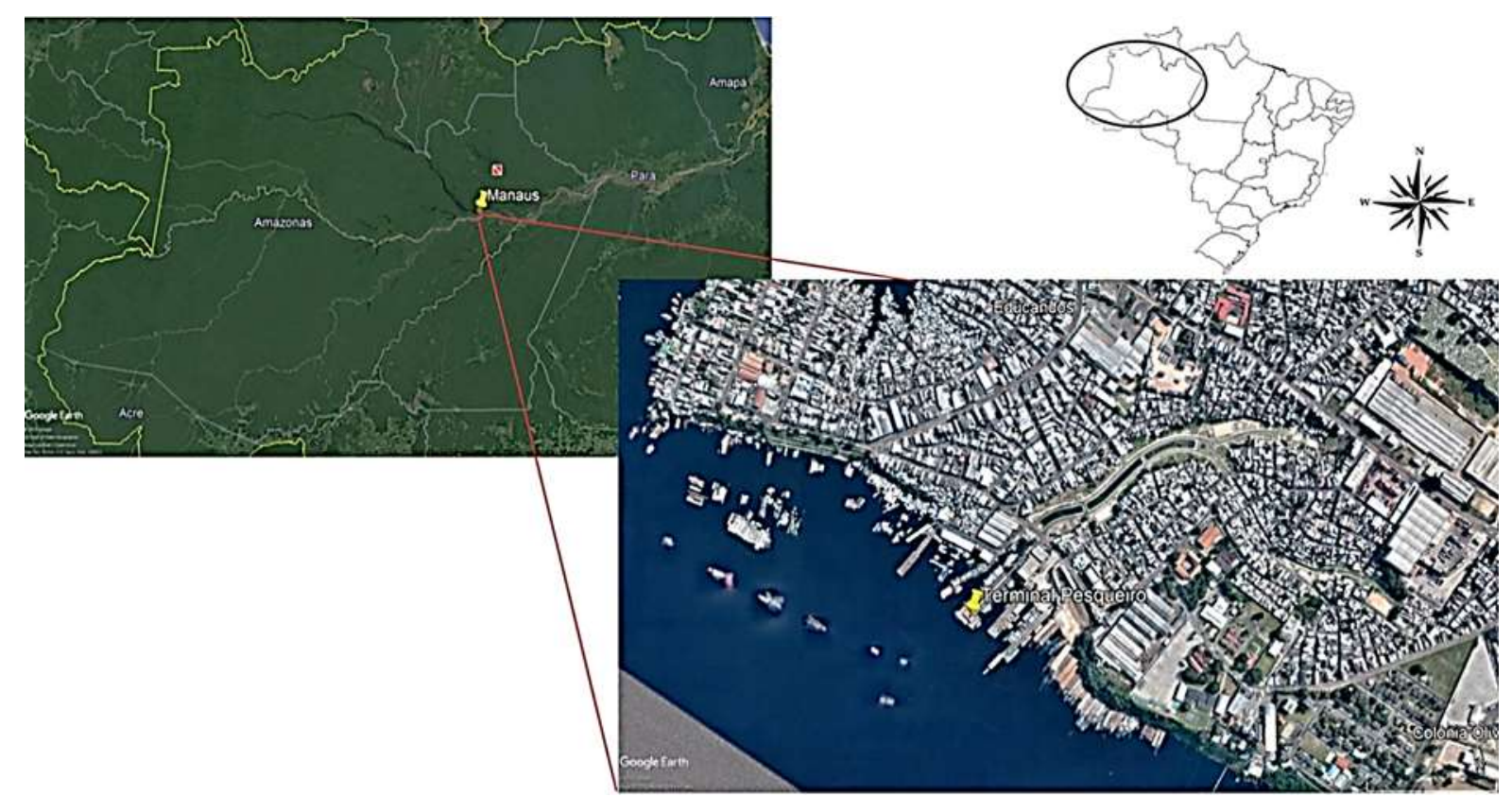

Figura 1: Mapa da Amazônia Central, com destaque para o Porto da Panair na cidade de Manaus-AM. Fonte: Google Earth

\section{COLETA DE DADOS}

Os dados utilizados no presente estudo foram secundários, estes correspondem aos anos de 2012 e 2013. Os dados de produção e esforço foram disponibilizados pela Colônia dos Pescadores Z12, na qual este órgão realizou a coleta diariamente, no horário de comercialização do pescado, abordando todos os barcos que atracavam no Porto da Panair. As informações obtidas foram: desembarque em quilograma por barco, desembarque em quilograma por rio e o número de barcos. A variável tipo de água, feita a partir da denominação do rio de origem do desembarque presente no banco de dados, foi classificada de acordo com o disponível na literatura. 
Os dados de ciclo hidrológico foram coletados no porto de Manaus e disponibilizados pela Agência Nacional de Águas (ANA), na qual usamos como referência as cotas do Rio Negro.

\section{ANÁLISES DOS DADOS}

\section{CÁLCULO DA CAPTURA POR UNIDADE DE ESFORÇO}

A CPUE é uma estimativa da abundância do recurso pesqueiro podendo ser definido como, quanto mais eficiente for a arte pesca, maior a capacidade de capturar peixes, sendo uma relação direta entre esforço e resultado (SPARRE e VANEMA, 1997). O cálculo de Captura por Unidade de Esforço (CPUE) foi gerado conforme descrito na fórmula abaixo:

$$
C P U E=\frac{P}{E}
$$

Onde P é a produção $(\mathrm{kg})$ mensal desembarcada da matrinxã, e E o esforço representado pelo número de barcos por mês, ambos retirados do banco de dados.

\section{ANÁLISES ESTATÍSTICAS}

O teste de Análise de Variância (Anova One-way), em nível de significância 5\%, foi usado para testar as variações de produção $(\mathrm{kg})$ com relação aos rios de origem, nos quais a repetição foi a resposta obtida de cada pescador disponível no banco de dados. Como houve diferença estatística na produção entre os rios, foi utilizado o teste LSD Fisher para verificar quais rios se diferenciavam em relação à produção. Para analisar a produção de acordo com o tipo de água foi aplicado o teste t de Student. Todas as análises foram realizadas separadamente por ano, a fim de facilitar comparações entre as mesmas.

\section{HIPÓTESES}

H0: O desembarque do matrinxã não muda de acordo com o rio de origem.

HO: O desembarque do matrinxã não varia de acordo com o tipo de água.

\section{RESULTADOS E DISCUSSÃO}

A produção (kg) desembarcada da matrinxã (Brycon spp.) no Porto da Panair em Manaus, de acordo com o regime fluvial $(\mathrm{m})$ do rio Negro, variou durante o ano com picos de produção (Figura 2) no mês de abril (enchente), com $564.900 \mathrm{~kg}$ desembarcadas em 2012, e em maio (enchente) com $84.900 \mathrm{~kg}$ 
desembarcadas no ano de 2013. Destacamos que no ano de 2012, não houve desembarque da espécie em questão nos meses de janeiro e dezembro, considerado período de enchente. No ano de 2013, não houve desembarque nos meses de janeiro, setembro (vazante), novembro e dezembro (seca). Retirando os meses em que não houve desembarque, a menor produção no ano de 2012 ocorreu no mês de fevereiro com $1.000 \mathrm{~kg}$ desembarcadas e em 2013, no mês de outubro com $800 \mathrm{~kg}$ desembarcadas.

A oscilação do nível dos rios na Amazônia possui influência direta nas capturas pesqueiras, apresentando picos de produção ao longo do ano, com destaque para o período de enchente que corresponde a época de migração de espécies como a matrinxã (FREITAS e RIVAS, 2006), o que coincide com o momento em que esta espécie é capturada nesta pesquisa.

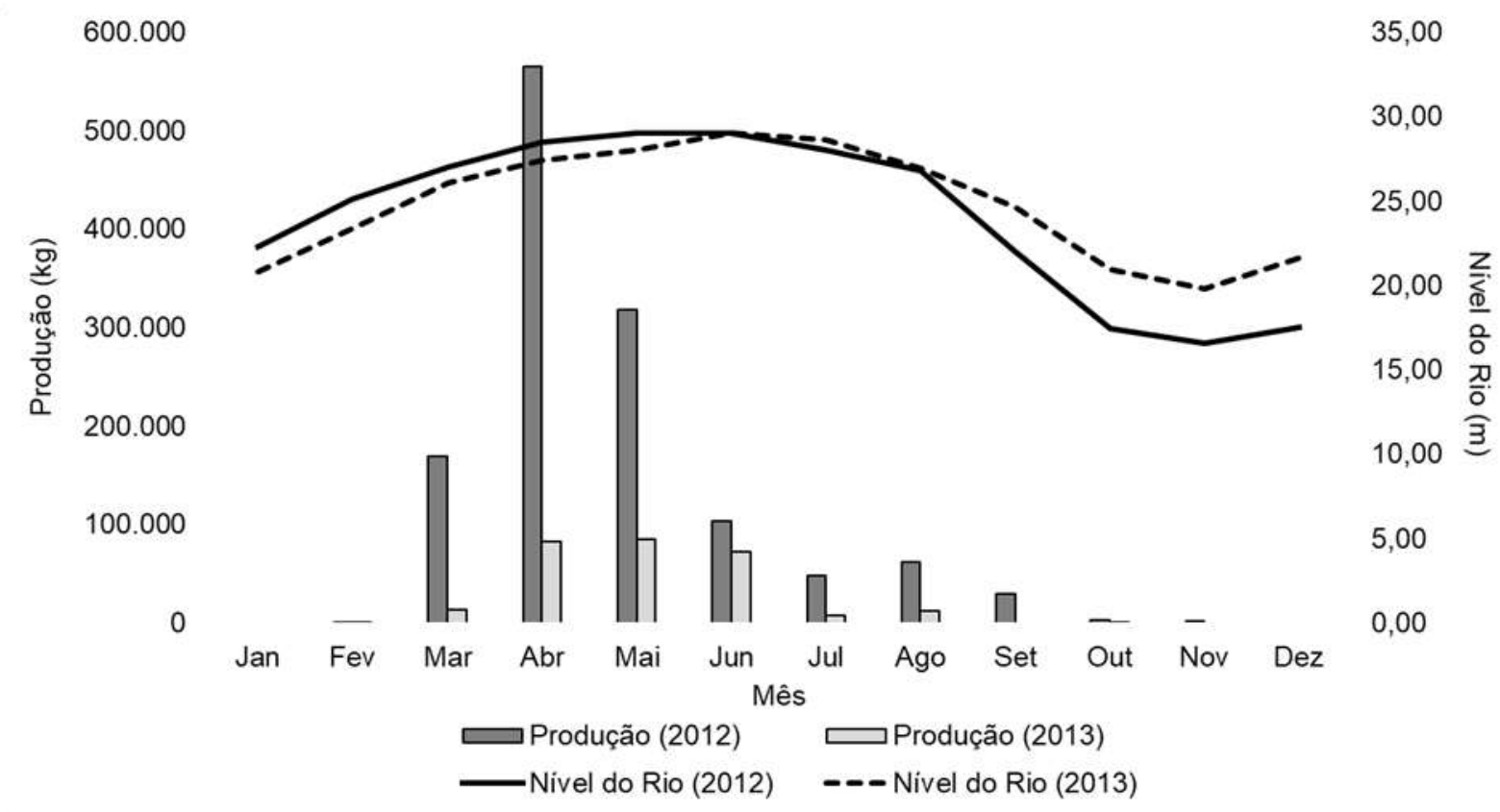

Figura 2: Oscilação do desembarque da matrinxã (Brycon spp.) no Porto da Panair de acordo com o nível do rio Negro nos anos de 2012 e 2013

Em Benjamin Constant, Lopes e Freitas (2018) encontraram que o maior desembarque pesqueiro ocorreu no mês de abril e estavam associados a captura de espécies como a matrinxã. Matos et al. (2018) analisando o desembarque pesqueiro em Manacapuru no ano de 2012, observou que entre as espécies mais desembarcadas estava a matrinxã e esta apresentou maior produção (kg) no mês de abril e menor produção no mês de junho. Além disso, o autor ainda relata que não houve desembarque nos meses de setembro, outubro, novembro e janeiro. Coincidindo com os meses de ausência ou baixas capturas desembarcadas em Manaus nos anos testados. Gonçalves (2018), 
analisando o desembarque pesqueiro no mesmo município, observou que a produção da matrinxã foi expressiva durante o período de enchente.

Cutrim (2005) analisando a pesca da matrinxã e seu desembarque na cidade de Manaus observou que em anos subsequentes de cheias fracas houveram os maiores picos de produção dessa espécie, na qual a safra da espécie ocorreu entre os meses de abril e junho, logo, o maior desembarque ocorreu na enchente e o menor durante a seca. Ayala et al. (2018) já supõem que as maiores produções, da espécie em questão, encontradas em seu estudo, podem ter sido influenciadas por cheias anormais. Comparando com os resultados obtidos a cheia extrema em 2012, não favoreceu a produção de matrinxã de 2013 , onde todos os valores mensais foram abaixo de 2012 , contudo pode ter havido favorecimento nos outros anos que se seguiram, pois muitas vezes o efeito de uma grande cheia vai aparecer em anos seguintes, variando o tempo de resposta com a biologia de cada espécie e da dinâmica da pescaria (CUSHING, 1996; SOUZA e FREITAS, 2001).

De acordo com a Portaria № 48 de 5 de novembro de 2007 do IBAMA, a pesca de matrinxã para comercialização é proibida entre 15 de novembro à 15 de março. Excepcionalmente, a Instrução Normativa Interministerial de № 5 de 29 de março de 2012 (IBAMA, 2012), prorrogou o período de defeso da Portaria anteriormente citada, até o mês de maio no mesmo ano. O resultado obtido nesta pesquisa revela que a pesca da espécie em questão ocorreu durante o período em que esta é proibida. Para Cutrim (2005), a proteção das áreas reprodutivas da matrinxã, localizadas nos encontros de águas, e a mudança da época de defeso para o período de maior migração da espécie seriam medidas mais adequadas para conservação.

O cálculo a CPUE da matrinxã (Figura 3), nos mostra que no ano de 2012, seu máximo ocorreu no mês de abril (enchente) com 4.247,37 (kg/ $\mathrm{n}^{\circ}$ barcos), correspondendo ao mês de maior produção. De

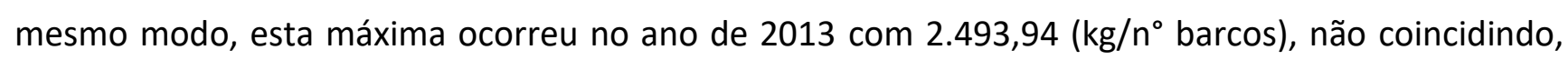
portanto, com o maior mês de produção. Para ambos os anos analisados, nos meses em que não houve desembarque da espécie, a CPUE foi igual a 0. Logo, retirando os meses sem produção, no ano de 2012 a menor CPUE obtida ocorreu no mês de novembro (seca) com 600 ( $\mathrm{kg} / \mathrm{n}^{\circ}$ barcos), correspondendo ao $2^{\circ}$ mês de menor produção. Para o ano de 2013, obtivemos a menor CPUE igual a 500 ( $\mathrm{kg} / \mathrm{n}^{\circ}$ barcos) no mês de fevereiro (enchente), $2^{\circ}$ mês de menor produção. 


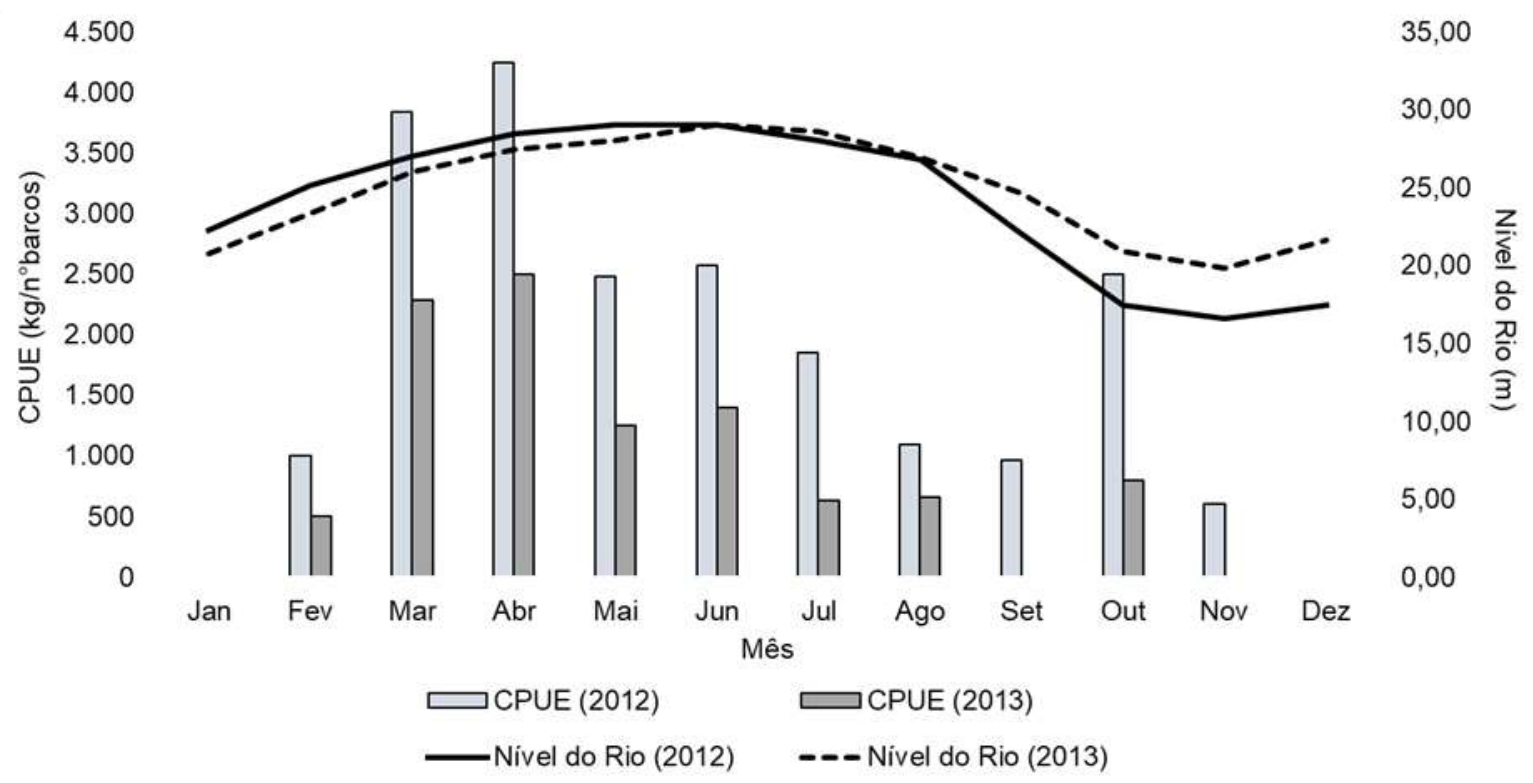

Figura 3: Oscilação da CPUE (t/n ${ }^{\circ}$ barcos) para a matrinxã (Brycon spp.) de acordo com o nível do rio Negro nos anos de 2012 e 2013

A matrinxã e realiza alguns tipos de deslocamentos durante seu ciclo de vida e pode ser encontrada em diversos ambientes dependendo do regime fluvial e da fase de vida. No período de enchente, desce os afluentes em grandes cardumes e realiza desova total nas águas do tipo branca, já durante a enchente e cheia sobe os rios a procura de alimento na floresta alagada, além disso, quando os ambientes estão secando a espécie sai deste para os canais principais dos rios (LOPES, 2015). O pescador conhece os períodos migratórios e sabem que esse é o momento ideal para captura destes animais e que terá bons rendimentos, com isso, a pesca no período da enchente é intensa (CUTRIM, 2005) consequentemente a CPUE aumenta como observado neste estudo.

Gonçalves (2018) encontrou resultados similares para a pesca multiespecífica da Amazônia central quanto a CPUE, no qual ela foi maior nos meses de enchente, abril e maio, estando a matrinxã entre as espécies que contribuíram para esse aumento. Para Ayala et al. (2018) a CPUE pode ser influenciada pela alta demanda de pescado, como foi observado pelos autores para cidade de Porto Velho, onde parece haver certa pressão nos estoques pesqueiros.

Cutrim (2005) sinaliza que, algumas décadas atrás, a matrinxã não se encontrava entre as espécies mais desembarcadas nos portos do Estado e com o passar dos anos, esta foi subindo no ranking de espécies preferenciais, isto não significa que haja sobrepesca, contudo, é possível observar um aumento do esforço na pesca desta espécie. Ainda de acordo com este autor, o grande desembarque 
de matrinxã pode ser relacionado a diferentes fatores, como o alto valor que a espécie possui no mercado, sugerindo então que sua pesca seja lucrativa para o pescador.

A análise obtida pela Anova, de acordo com o nível de significância de 5\%, mostrou que no ano de 2012 (Figura 4), houve diferença $(p<0,001)$ na produção $(\mathrm{kg})$ desembarcada da matrinxã segundo o rio de origem, rejeitamos, portanto, a hipótese nula. A maior média de produção corresponde ao Rio Jari e a menor, ao rio Madeira, provavelmente a baixa contribuição desse rio se deve a venderem parte do seu pescado capturado em Porto Velho, cidade que fica a sua margem, reduzindo assim os desembarques destinados a Manaus. O teste LSD de Fisher, revelou quais rios possuem produção média estatisticamente diferente entre si (Tabela 1).

Para o ano de 2013 (Figura 5), a análise mostrou que não houve diferença estatística $(p=0,07)$ na produção média entre rios. Aqui, aceitamos a hipótese nula. Sendo assim, não foi necessário realizar o teste LSD Fisher.

Cutrim (2005) em suas análises sobre o desembarque da matrinxã na cidade de Manaus faz algumas observações quanto ao ambiente de pesca que originaram esse desembarque. $O$ autor observou que o rio Purus foi o maior contribuinte e que a pesca ocorreu em boa parte no entorno deste rio, sem ser o canal principal, como no caso do rio Jari que se destacou no presente estudo, sendo este um dos principais pesqueiros que compõe este sistema do rio Purus, evidenciando a importância deste rio para pesca dessa espécie. Dentre outros rios que foram expressivos quanto à produção desembarcada desta espécie, estão os rios Madeira e Solimões. Baseado nisso, Cutrim (2005) recomenda que sejam implementadas estratégias de manejo considerando as características de cada subsistema fluvial, para garantir a sustentabilidade do recurso. 


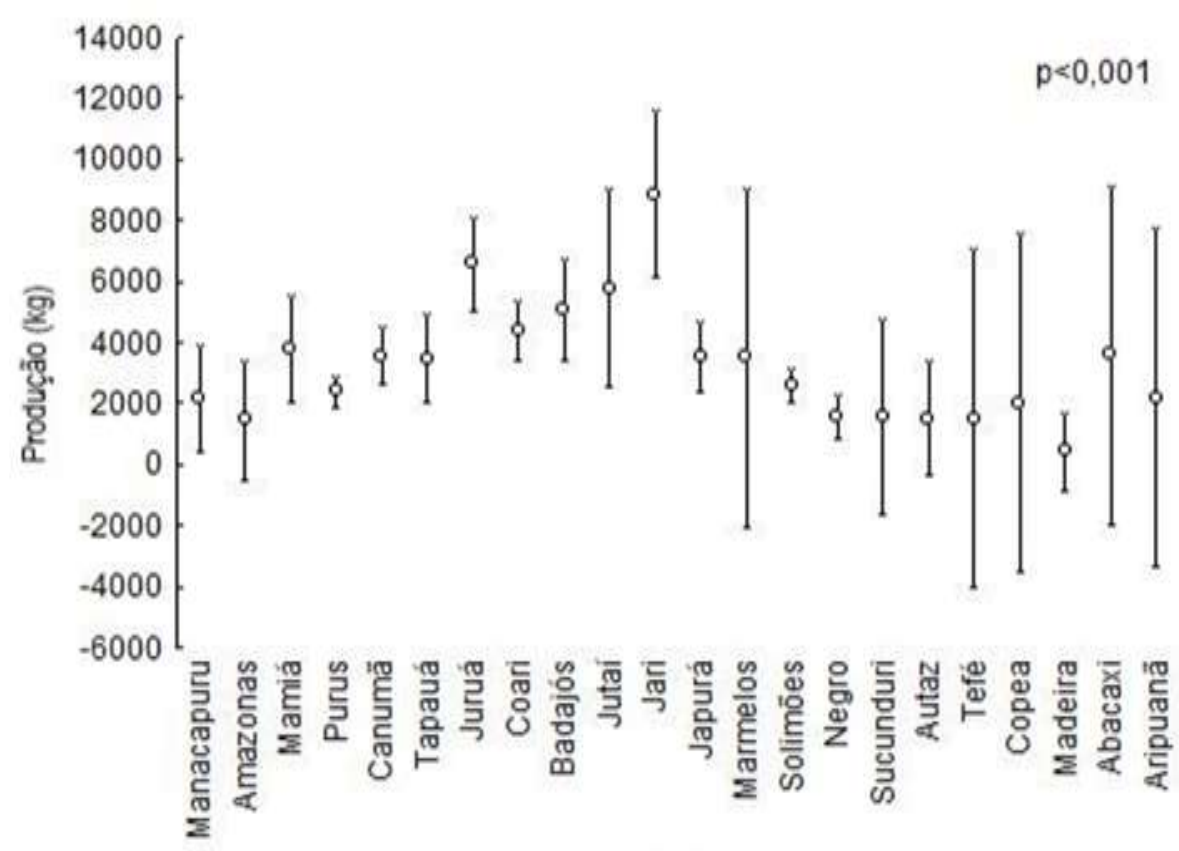

Rio

Figura 4: Variação das médias de produção (kg) para a matrinxã (Brycon spp.) nos diferentes ambientes de pesca no ano de 2012

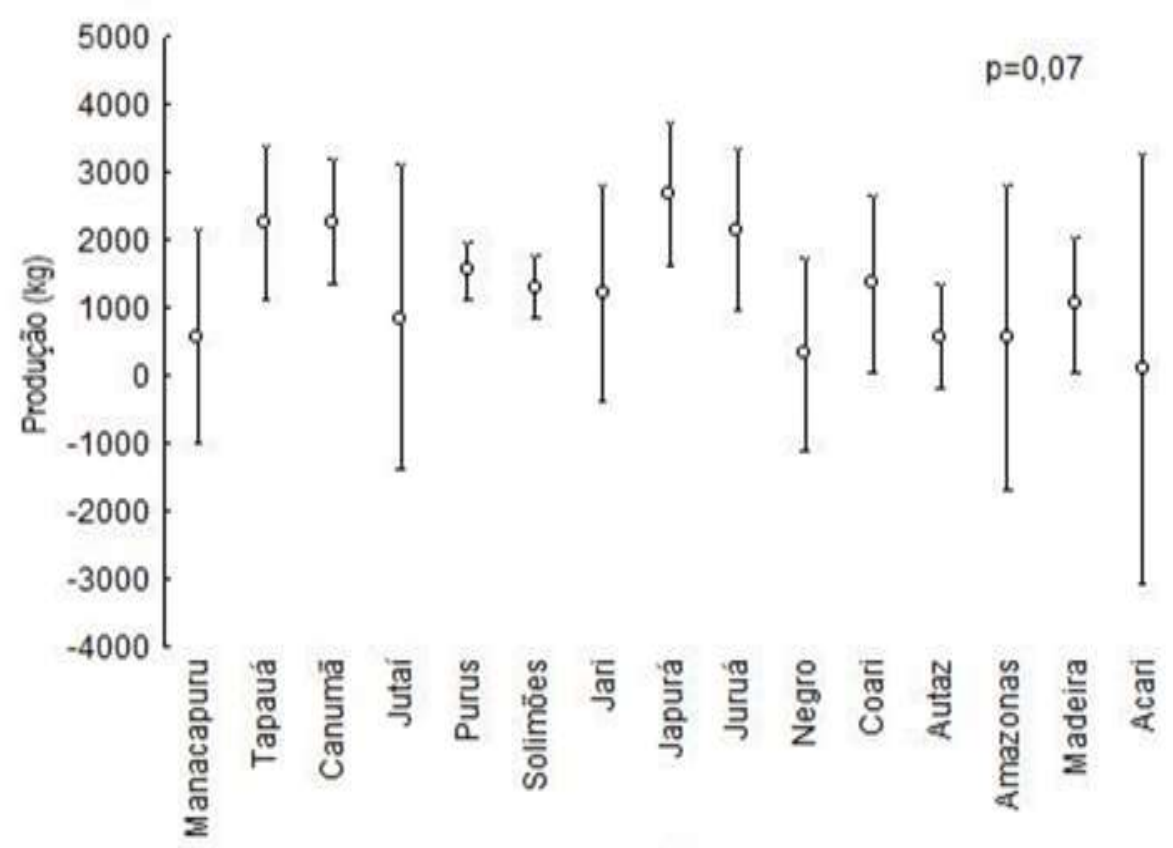

Rio

Figura 5: Variação das médias de produção $(\mathrm{kg})$ para a matrinxã (Brycon spp.) nos diferentes ambientes de pesca no ano de 2013 
Tabela 1. Resultado do teste LSD Fisher, para os dados de 2012, de comparação de médias de produção de cada rios entre si. a: $p \leq 0,05 ; b: p \geq 0,05$

\begin{tabular}{|c|c|}
\hline Abacaxib & Jutaía \\
\hline Amazonasa & Maadeiraa \\
\hline Aripuanãa & Mamiáa \\
\hline Autaza & Manacapurua \\
\hline Badajósa & Marmelosb \\
\hline Canumãa & Negroa \\
\hline Coaria & Purusa \\
\hline Copeáa & Solimões ${ }^{a}$ \\
\hline Japuráa & Sucunduria \\
\hline Jaria & Tapauáa \\
\hline Juruáa & Teféa \\
\hline
\end{tabular}

A análise da produção $(\mathrm{kg})$ desembarcada da matrinxã de acordo com o tipo de água, aqui identificada apenas águas brancas e pretas, revelou que tanto em 2012 (Figura 6) quanto em 2013 (Figura 7), a produção da espécie nesses ambientes foi estatisticamente igual ( $p>0,05)$. Logo, aceitamos a hipótese nula.

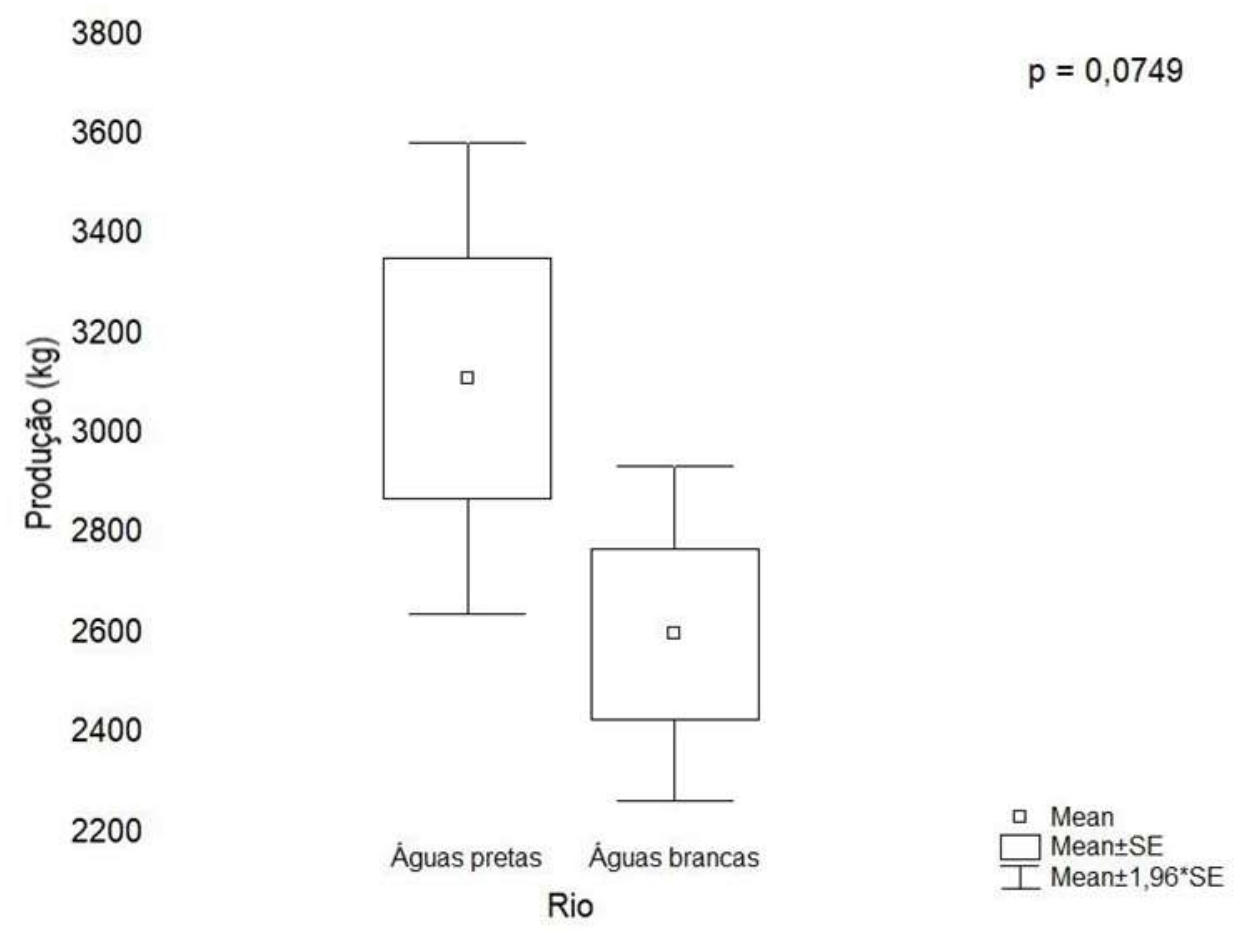

Figura 6: Desembarque da matrinxã (Brycon spp.) entre água branca e água preta no ano de 2012 
2000

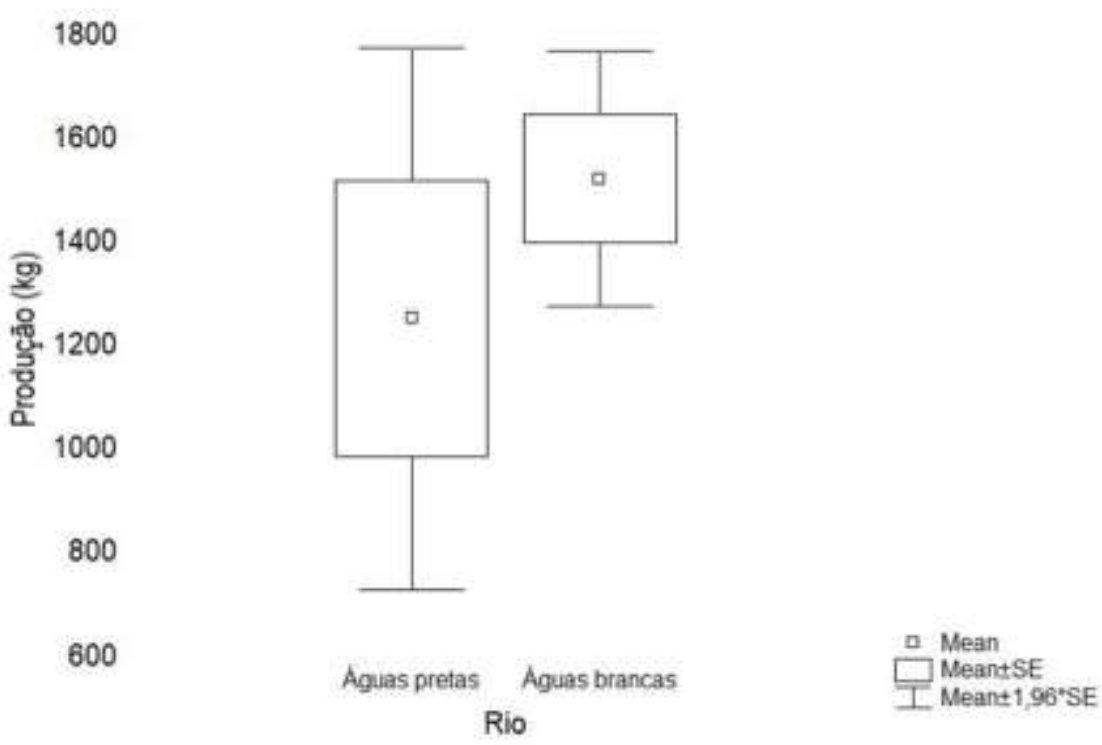

Figura 7: Desembarque da matrinxã (Brycon spp.) entre água branca e água preta no ano de 2013 Pereira (2015) em sua pesquisa sobre a pesca em Novo Aripuanã, revela que segundo os pescadores, a matrinxã é mais capturada em rios de água preta do que em ambientes de água branca, mas também são encontradas tanto áreas de várzea quanto em igarapés, o que não foi verificado no presente estudo. Para Isaac e Barthem (1995), a intensidade da pesca nos rios de água branca é maior durante a seca, principalmente porque espécies migradoras estão adensadas no canal principal. Esta relação da produção de matrinxãs com o tipo de água muitas vezes está associado ao direcionamento do esforço em regiões de água branca em detrimento do rio de águas pretas, nem sempre tendo uma relação com a abundância desta espécie nesses ambientes.

\section{CONCLUSÃO}

Os maiores desembarques de matrinxã ocorreram no período de enchente.

Mesmo no período de defeso da espécie, houve desembarque desta, até mesmo no ano em que este foi prorrogado.

A CPUE acompanhou os meses de maior produção, excetuando no ano de 2013, onde maior valor mensal obtido não obteve o maior desembarque.

A produção desembarcada da espécie em questão foi diferente de acordo com o rio de origem apenas para o ano de 2012.

A produção independeu do tipo de água, se preta ou branca. 


\section{REFERÊNCIAS}

AYALA, D. M., LIMA, M. A. L., HAUSER, M., DORIA, C. R. C. Jatuarana fishing dynamics Brycon amazonicus (Spix \& Agassiz, 1829) of the upper and middle Madeira River Basin. Acta Scientiarum. Biological Sciences, v. 40, p. 1-11, 2018.

BARTHEM, R.; GOULDING, M. The catfish connection: ecology, migration, and conservation of Amazon predators. Columbia University Press, 1997.597p.

BENACON, M. S.; SANTOS, S. M.; ARAÚJO, R. L.; PANTOJA-LIMA, J.; ARIDE, P. H. R.; OLIVEIRA, A. T. Índices de condición corporal de Matrinxã Brycon Amazonicus del Río Juruá, Amazonas. Revista Colombiana de Ciência Animal-RECIA, v. 7, n. 1, p. 44-49, 2015.

CUSHING, D. H. Toward a Science of recruitment in fish populations. Excellence in ecology. Ecology Institute: Germany, 1996. 175p

CUTRIM, L. Avaliação da explotação pesqueira e dinâmica populacional de matrinxã (Brycon amazonicus) (Günther, 1869) na Amazônia Central através do desembarque pesqueiro realizado em Manaus. Mestrado INPA/UFAM, Manaus, 114pp, 2005.

FASSONI-ANDRADE, A. C.; PAIVA, R. C. D. Dinâmica espaço temporal de sedimentos em rios e lagos na bacia Amazônica utilizando dados modis. Anais do Simpósio Brasileiro de Recursos Hídricos, ABRH, 2017.

FREITAS, C. E. C.; RIVAS, A. A. F. A pesca e os recursos pesqueiros na Amazônia Ocidental. Ciência e Cultura, v. 58, n. 3, p. 30-32, 2006.

GONÇALVES, V. V. C. Influência do ciclo hidrológico em pescarias comerciais na Amazônia Central, Brasil. Dissertação (Mestrado em Ciências Pesqueiras nos Trópicos) - Universidade Federal do Amazonas, Manaus, 63p. 2018.

GONZALES, A., CURTO, G.; FERNÁNDEZ-MENDEZ, C. Parámetros hematológicos de reproductores de Brycon amazonicus (Bryconidae) en cultivo. Revista de Investigaciones Veterinarias del Perú, 30(1), 133-142, 2019.

IBAMA. Instrução Normativa Interministerial de № 5 de 29 de março de 2012.

ISAAC, V. J.; BARTHEM, R. B. Os Recursos pesqueiros da Amazônia brasileira. Boletim do Museu Paraense Emílio Goeldi. Série Antropologia, Belém, v. 11, n. 2, p. 295-339. 1995.

LOPES, A. C. C. Luminosidade e Melatonina Como Moduladores da Agressividade Em Matrinxã, Brycon Amazonicus (Characiformes: Characidae). Manaus, Amazonas, Dissertação de Mestrado em Aquicultura. Universidade Nilton Lins. 2015. 38p.

LOPES, G. C. S.; FREITAS, C. E. C. Avaliação da pesca comercial desembarcada em duas cidades localizadas no rio Solimões-Amazonas. Biota Amazônia, v. 8, n. 4, p. 36-41, 2018.

MATOS, O. F.; LOPES, G. C. S.; FREITAS, C. E. C. A pesca comercial no baixo rio Solimões: uma análise dos desembarques de Manacapuru/AM. Biota Amazônia, v. 8, n. 4, p. 1-8, 2018. 
MATTOS, B. O., BUENO, G. W., HONCZARYK, A., PEREIRA-FILHO, M.; ROUBACH, R. Níveis de proteína bruta na dieta de juvenis de matrinxã (Brycon amazonicus). Revista de Ciências Agrárias: Amazonian Journal of Agricultural and Environmental Sciences, 61. 2018.

NAKAUTH, A. C. S. S.; VILLACORTA-CORREA, M. A.; FIGUEIREDO, M. R.; BERNARDINO, G.; FRANÇA, J. M.; NAKAUTH, A. C. S. S.; VILLACORTA-CORREA, M. A.; FIGUEIREDO, M. R.; BERNARDINO, G.; FRANÇA, J. M. Embryonic and larval development of Brycon amazonicus (SPIX \& AGASSIZ, 1829). Brazilian Journal of Biology, v. 76, n. 1, p. 109-116, 2016.

PEREIRA, H. S.; CARDOSO, R. S. Caracterização Da Pesca Extrativa Comercial E De Subsistência do Município de Novo Aripuanã (Rio Madeira), Amazonas. Anais do XIII Congresso Brasileiro de Engenharia de Pesca, Porto Seguro/BA. 2015.

SILVA, S. H.; NODA, S. N. A Dinâmica entre as águas e terras na Amazônia e seus efeitos sobre as várzeas. Ambiente \& Água - An Interdisciplinary Journal of Applied Science, v. 11, n. 2, 2016.

SORRIBAS, M. V., PAIVA, R. C. D. D., COLLISCHONN, W., FLEISCHMANN, A. S.; BONNET, M. P. Estudo da Bacia Amazônica com um modelo de rastreamento hidrológico. Anais do Simpósio Brasileiro de Recursos Hídricos. 22.: Florianópolis, 2017.

SOUZA, L. A.; FREITAS, C. E.C. Relação entre o pulso de inundação e a produção pesqueira do Estado do Amazonas, Brasil Ciências Agrárias e Ambientais, Revista da UFAM, Manaus, v. 1, n. 1/2, p. 73-86. 2001.

SPARRE, P.; VENEMA, S.C. Introdução à avaliação de mananciais de peixes tropicais. Parte 1: Manual. FAO Documento Técnico sobra as Pescas. No. 306/1, Rev.2. Roma, FAO. 404p. 1997. 


\section{Capítulo 4}

doi $10.37423 / 210904737$

\section{VARIAÇÃO ESPACIAL E SAZONAL DA PESCA DO JARAQUI (SEMAPROCHILODUS SSP.) DESEMBARCADO EM MANAUS/AM}

Williams Ricardo Neves da Cunha Junior

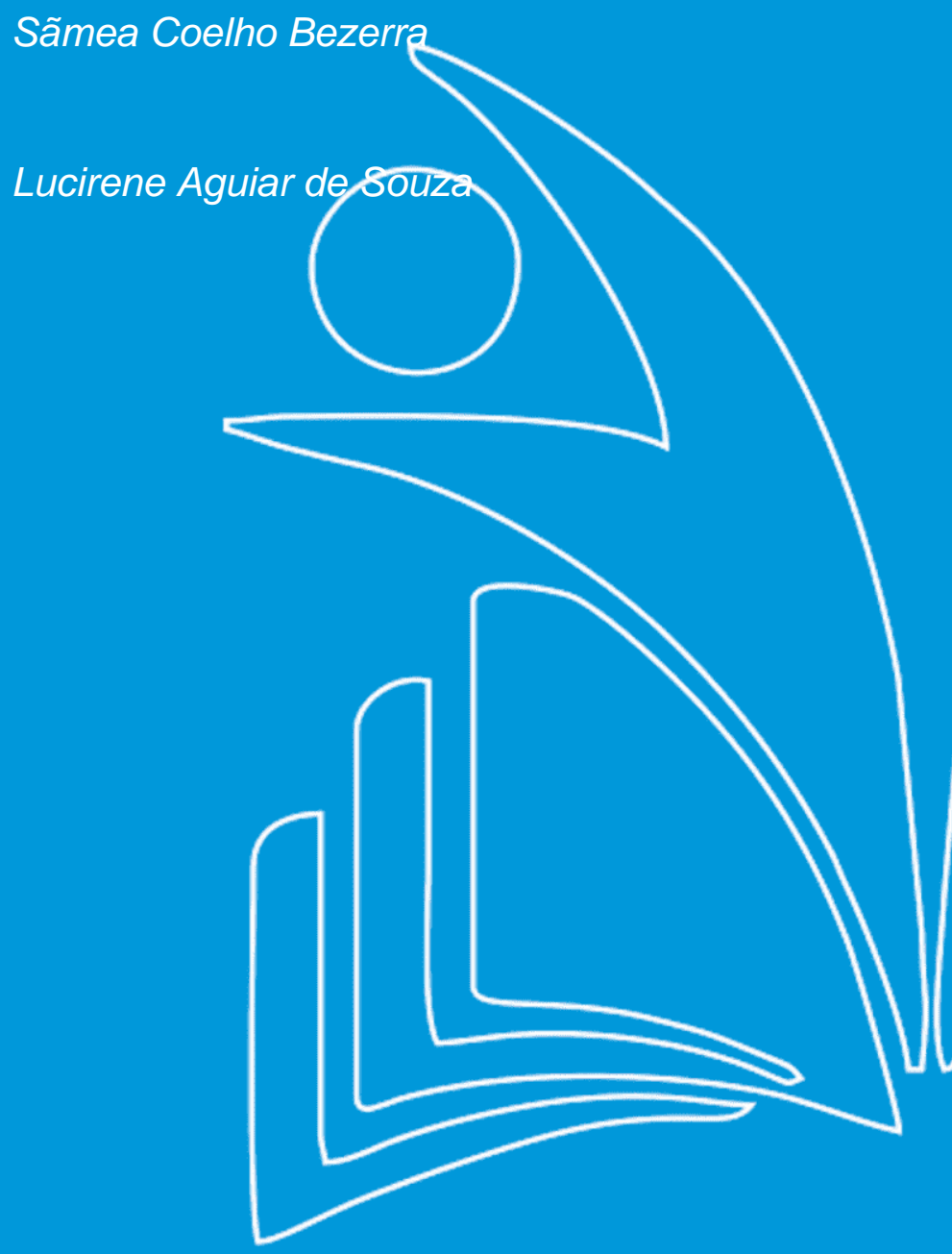

Graduando em Engenheiro de Pesca,

Universidade Federal do Amazonas

Mestrado em Engenharia de Produção UFAM, SEDUC-AM

Doutora em Biología de Águr Doce e Pesca Interior, Plofess dra Associada da FCAVUFAM 
Resumo: O jaraqui é uma das espécies mais importantes para a população da cidade de Manaus. Por este motivo, este trabalho visa avaliar a variação espacial e sazonal de fatores ligados à pesca como: produção e CPUE do jaraqui (Semaprochilodus spp.), a partir de dados disponibilizados pela Colônia de Pescadores Z-12, que correspondem ao desembarque pesqueiro no Porto da Panair em Manaus/AM; verificando sua interação com o ciclo hidrológico e com o rio de origem. Para comparação da produção entre rios foi feito um teste de ANOVA para qual observou-se que havia diferença significante entre os rios. Podemos também verificar que os principais rios que se destacam são: Tefé, Jutaí, Ipixuna e Tapuá. O período de maior produção dos jaraquis foi na cheia e a CPUE foi maior durante a enchente e cheia.

Palavras-chave: CPUE; Produção Pesqueira; Pulso de inundação. 


\section{INTRODUÇÃO}

O produto da pesca representa a principal fonte proteica na alimentação amazônica (CAD, 2017, NASCIMENTO, 2017). Na região amazônica as pescarias têm se concentrado nos Characiformes (LOPES et al, (2017), com destaque para os jaraquis, que englobam duas espécies: o de escama fina (Semapraochilodus taeniurus), e o de escama grossa (Semaprochilodus insignis) (FARIA JR. e BATISTA, 2019). Os jaraquis são amplamente distribuídos em diversos tributários da Bacia Amazônica, pelos quais migram duas vezes ao longo do ano, estando essa movimentação relacionada com a flutuação do nível do rio. (DIAS-NETO, 2015)

A relação entre a produção do jaraqui com as características do ambiente como: a pesca, o nível do rio e o tipo de água, precisam ser compreendidas e monitoradas para evitar impactos nesse estoque pesqueiro tão importante, pois de acordo com Silva e Souza, (2017), este é o recurso mais importante para a população ribeirinha e de baixa renda. É nesse intuito que esse estudo buscou compreender quais as áreas da Amazônia Central são mais produtivas para o jaraqui e aquelas cujo desembarque é baixo, podendo servir tanto para guiar expedições pesqueiras para locais mais produtivos, como para dar suporte para escolha de áreas a serem protegidas, ou de medidas de proteção e mitigatórias para tentar evitar que esta espécie caminhe para sobrepesca.

\section{MÉTODO}

\section{ÁREA DE ESTUDO}

A área de estudo compreende os rios e lagos da Amazônia Central. E o ponto de coleta e principal local de desembarque e venda do pescado direto do produtor, na cidade de Manaus, localiza-se na feira municipal da Panair, que está situada no bairro do Educandos, 3 8'51.13"S 0600'38.01"O) (Figura 1). 


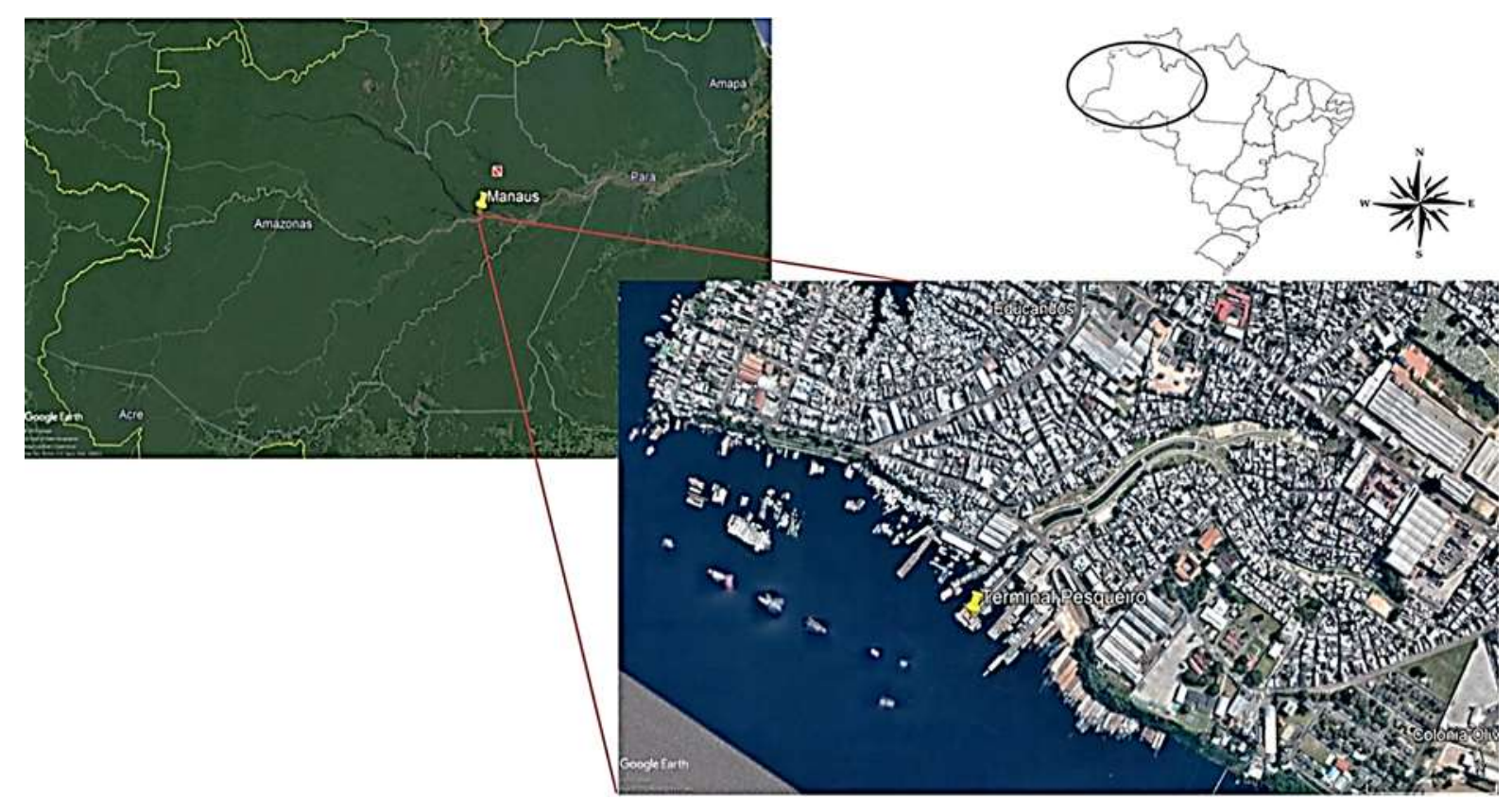

Figura 1: Mapa da Amazônia Central, com destaque para o ponto de coleta, Porto da Panair na cidade de Manaus-AM. Fonte: Google Earth

\section{COLETA DE DADOS}

As informações sobre a área de estudo foram disponibilizadas pela Colônia de Pescadores Z-12, que coleta, diariamente, junto aos pescadores comerciais na Feira da Panair, Manaus, Am. Os dados relativos ao ciclo hidrológico foram obtidos na Agência Nacional de Águas. Os dados utilizados nesse trabalho foram: desembarque em kg por barco, desembarque em kg por rio, número campanhas de pesca e ambiente de pesca.

\section{CÁLCULO DA CPUE}

Segundo Sparre e Venema (1997) A CPUE (Captura por Unidade de Esforço), é uma estimativa que representa a abundância dos estoques pesqueiros. Os cálculos foram realizados através da fórmula:

$$
C P U E=\frac{C}{E} \text {. Onde: }
$$

$\mathrm{C}=$ é a captura pesqueira de jaraqui desembarcada mensalmente na área de estudo;

$E$ = é o esforço representado pelo número de barcos por mês que desembarcaram jaraqui na Panair.

\section{ANÁLISE ESTATÍSTICA}

Foram feitas Análise de Variância de uma entrada em nível de significância 0,05\% (ALI e BHASKAR, 2016). A análise testou se há diferença na produção do jaraqui oriundos de rios e lagos, 
desembarcados em Manaus. Quando houve diferença foi executado o teste de $\mathrm{N}$ desigual (HSD) comparando os fatores um a um. A variação da produção e da CPUE relacionados às fases do ciclo hidrológico foram feitos por meio de estatísticas descritivas. Em todos os testes, a repetição foi a resposta de cada pescador.

\section{RESULTADOS E DISCUSSÃO}

Ao todo foram analisados 38 ambientes de pesca, sendo 5 lagos e 33 rios (Tabela 1). 0 padrão de preferência pelos rios para execução das pescarias na região da Amazônia Central e Manacapuru, já foi observado por GONÇALVES et al. (2020). A superioridade do ambiente de rio em relação aos lagos para os jaraquis já era esperada, uma vez que este é o principal habitat dessa espécie (GUERREIRO et al 2020; VALÉRIO JR. 2019; SOARES 2017). A baixa frequência de referência aos lagos, principalmente os de água branca, é bem vista, uma vez que estas são áreas de alimentação e abrigo das larvas e juvenis (PONTE et al., 2019), um número maior de campanhas para esse tipo de ambiente poderia indicar que estão capturando indivíduos de pequeno porte. Algumas regiões de captura são bastante distantes de Manaus, assim o fator distância pode ter influenciado os resultados das escolhas por ambientes mais próximos. De acordo com Junk (1983) as migrações de jaraquis podem exceder centenas de quilômetros, o que amplia muito as áreas e ambientes de captura.

De acordo com Matos (2020), os jaraquis estão relacionados ao ambiente de rio de águas brancas, claras e pretas, porém neste trabalho, nenhum ambiente de água clara foi citado. Dos 38 ambientes analisados, 23 foram de água branca e 8 de água preta, indicando que os jaraquis são mais procurados em rios de água barrenta como local da pescaria. A superioridade no número de ambientes de água branca já era esperada, pois estes consistem em áreas reconhecidas como de maior produtividade pesqueira (PEREIRA, 2020). Uma contribuição maior para desembarque de pescado, também é observada em lagos que recebem, pelo menos, em uma parte do ano, fluxo de rios de água branca, como o Lago do Rei (BITTENCOURT, 1994) e o lago do Janauacá (FISCHER, 1978). Esta conexão entre ambientes na época da cheia, possibilita a movimentação dos peixes entre os ambientes citados e colabora para a manutenção da diversidade nesses sistemas (GOMES, 2016). 
Tabela 1. Ambientes de pesca analisado

\begin{tabular}{|l|l|l|l|}
\hline \multicolumn{4}{|c|}{ Ambientes: Lagos e Rios } \\
\hline 1.Rio Autaz & 11.Rio Badajos & 21.Rio Branco & 31.Lago do Janauacá \\
\hline 2.Rio Canumã & 12.Rio Manacapuru & 22.Rio Mamori & 32.Rio Preto \\
\hline 3.Rio Tapauá & 13.Rio Coari & 23.Lago Do Já & 33.Rio Acari \\
\hline 4.Rio Japurá & 14.Rio Mamiá & 24.Rio Marmelo & 34.Rio Sucunduri \\
\hline 5.Rio Purus & 15.Lago Do Manaquiri & 25.Rio Ipixuna & 35.Rio Jaraqui \\
\hline 6.Rio Gamboa & 16.Rio Sapatini & 26.Rio Juruá & 36.Lago de Coari \\
\hline 7.Rio Jutaí & 17.Rio Arariá & 27.Rio Aripuanã & 37.Rio Copea \\
\hline 8.Rio Pioreni & 18.Rio Tefé & 28.Baixo Amazonas & \multirow{2}{*}{ 38.Rio Arini } \\
\cline { 1 - 2 } 9.Rio Ayapuá & 19.Rio Madeira & 29.Lago dos Reis & \\
\hline 10.Rio Jary & 20.Rio Solimões & 30. Rio Negro & \\
\hline
\end{tabular}

Os resultados da Anova para o ano de 2012, ano que houve uma cheia extrema na região, que durou cerca de 230 dias, e ocasionou diversos prejuízos no interior e na capital (CPRM, 2012), mostraram que houve diferença significante entre os rios e lagos que contribuem com jaraquis para a cidade de Manaus ( $p=0,00001)$. As análises da ANOVA feitos para 2013, também encontraram diferenças significante entre os ambientes testados $(p=0,000000000000001)$.

Quando testados um a um, verificamos que ocorreram algumas diferenciações estatisticamente significantes (Tabela 2). O ano de 2013 teve maior número de rios com diferença significante do que 2012. Talvez isso se deva ao ano de 2012, ter havido um número menor de ambientes de pesca do que no ano de 2013, isso pode estar associado à grande cheia recorde do ano de 2012 (CPRM, 2012), mas para testar essa hipótese, nós precisaríamos ter um maior número de anos de coleta em nossas análises. Grande parte das variações estão associadas a não separação dos rios e lagos para execução da análise. Este será o próximo passo dessa pesquisa.

O rio Tapauá foi o que mais se diferencio vários ambientes tanto em ambos os anos testados. Este é um rio de água branca pouco estudado no âmbito das ciências pesqueiras, sendo na maioria das vezes somente citado como um dos ambientes de pesca da Amazonia Central, quantificando as capturas totais (CORREA et al., 2018, SILVA et al., 2019). No Município de Tapauá, que é banhado por esse rio de mesmo nome, existem um grande número de unidades de conservação e terras indígenas (FROTA, 2017), que provavelmente contribuem para o uso sustentado dos estoques pesqueiros. 
Tabela 2. Resultados do teste post hoc HSD com diferença significante

\begin{tabular}{|l|l|}
\hline Análise de comparação dos ambientes de pesca um a um, para o ano de 2012 \\
\hline $\begin{array}{l}\text { Ambientes de } \\
\text { pesca }\end{array}$ & Ambientes que apresentaram diferenças significativas \\
\hline Rio Autaz & Rio Tapauá \\
\hline Rio Purus & Rio Solimões, Rio Negro \\
\hline Rio Tapauá & $\begin{array}{l}\text { Rio Solimões, Rio Branco, Lago do Janaucá, Rio Amazonas, Rio Negro, Rio } \\
\text { Badajós e Rio Manacapuru }\end{array}$ \\
\hline Rio Japurá & Lago do Janauacá, Rio Negro \\
\hline Rio Solimões & Rio Coari \\
\hline Rio Janauacá & Rio Mamiá \\
\hline Rio Negro & Rio Coari \\
\hline Análise de comparação dos ambientes de pesca um a um, para o ano de 2013 \\
\hline $\begin{array}{l}\text { Ambientes de } \\
\text { pesca }\end{array}$ & Ambientes que apresentaram diferenças significativas \\
\hline Rui Tapauá & $\begin{array}{l}\text { Rio Purus, Rio Badajós, Rio Tefé, Rio Madeira, Rio Solimões, Rio Branco, Rio } \\
\text { Aripuanã, Lago do Já e Lago dos Reis }\end{array}$ \\
\hline Rio Canumã & Lago do Já e Lago dos Reis \\
\hline Rio Japurá & Rio Purus, Rio Madeira, Rio Solimões, Rio Aripuanã, Lago do Já e Lago dos Reis \\
\hline Rio Purus & Rio Manacapuru e Lago do Já \\
\hline Rio Juataí & Rio Tefé, Rio Solimões, Rio Branco, Lago do Já e Lago dos Reis \\
\hline Rio Jary & Lago do Já e Lago dos Reis \\
\hline Rio Badajós & Lago do Já \\
\hline Rio Coari & Lago dos Reis \\
\hline rio Manacapuru & Madeira, Solimões, Aripuanã, Lago do Já e Lago dos Reis \\
\hline
\end{tabular}

Na Tabela 3, encontra-se o ranking dos rios mais produtivos no desembarque do jaraqui nos anos de 2012 e 2013. Podemos verificar que os principais rios que se destacam em produção do jaraqui são de água branca, com destaque para o Tefé, o Jutaí, o Ipixuna e o Tapuá. Reafirmando que estas regiões possuem alta produtividade biológica e geram elevada biomassa de peixes (PEREIRA, 2020).

Os ambientes que menos contribuem são os lagos (Coari e Janauacá) e os rios Sucunduri e Branco (Tabela 4). Pode ser verificado nessa tabela que há uma maior frequência de ambientes de água preta. Apesar desse resultado, Soares (2017) descreve que ambientes de água preta e de lagos são importantes para essa espécie durante a fase juvenil e durante migrações. Os cardumes de jaraquis adultos e maduros deslocam-se das áreas inundadas do baixo rio Negro até o rio Solimões, para desovarem e, posteriormente, retornarem as áreas inundadas do rio Negro. Onde se alimentarão intensivamente durante 3 meses (SOARES, 2017). A importância do Rio Negro para o jaraqui já foi observada por Junk (1983) e Guerreiro (2020), que relatam que estes migram por águas pretas, pobres em nutrientes, para os rios de águas brancas, onde irão desovar e, quando saem desses ambientes, são capturados em grandes quantidades. 
Tabela 3. Ranking dos cinco rios e lagos mais produtivos do ano de 2012 e 2013

\begin{tabular}{llll|llll}
\hline & \multicolumn{3}{c|}{ Ano 2012 } & \multicolumn{3}{c}{ Ano 2013 } \\
\hline Ranking & Rio/lago & Cor & $\begin{array}{l}\text { Produção } \\
(\mathbf{k g})\end{array}$ & Ranking & Rio/lago & Cor & $\begin{array}{l}\text { Produção } \\
\text { (kg) }\end{array}$ \\
\hline $1^{\circ}$ & Tefé & $\mathrm{B}$ & 8340,0 & $1^{\circ}$ & Ipixuna & $\mathrm{B}$ & 9300,0 \\
\hline $2^{\circ}$ & Tapauá & $\mathrm{B}$ & 7361,5 & $2^{\circ}$ & Tefé & $\mathrm{B}$ & 9150,0 \\
\hline $3^{\circ}$ & Jutaí & $\mathrm{B}$ & 6966,7 & $3^{\circ}$ & Jutaí & $\mathrm{B}$ & 7600,0 \\
\hline $4^{\circ}$ & Ipixuna & $\mathrm{B}$ & 6014,3 & $4^{\circ}$ & Tapauá & $\mathrm{B}$ & 7337,0 \\
\hline $5^{\circ}$ & Japurá & $\mathrm{B}$ & 5610,7 & $5^{\circ}$ & Japurá & $\mathrm{B}$ & 6638,6 \\
\hline
\end{tabular}

Tabela 4. Ranking dos cinco rios e lagos menos produtivos do ano de 2012 e 2013

\begin{tabular}{|c|c|c|c|c|c|c|c|}
\hline \multicolumn{4}{|c|}{ Ano 2012} & \multicolumn{4}{|c|}{ Ano 2013} \\
\hline Ranking & Rio/lago & Cor & $\begin{array}{l}\text { Produção } \\
\text { (kg) }\end{array}$ & Ranking & Rio/lago & Cor & $\begin{array}{l}\text { Produção } \\
\text { (kg) }\end{array}$ \\
\hline $1^{\circ}$ & Rio Sucunduri & $P$ & 300,0 & $1^{\circ}$ & Rio Acari & $P$ & 100,0 \\
\hline $2^{\circ}$ & Lago Coari & $\mathrm{P}$ & 1000,0 & $2^{0}$ & Rio Sucunduri & $P$ & 250,0 \\
\hline $3^{\circ}$ & Rio Branco & B & 1193,3 & $3^{\circ}$ & $\begin{array}{l}\text { Lago Manaquirí e } \\
\text { Janauacá }\end{array}$ & $B$ & 1000,0 \\
\hline \multirow[t]{2}{*}{$4^{\circ}$} & & $B$ & & $4^{0}$ & Rio Sapatini e & $\mathrm{B}$ & 1200,0 \\
\hline & Lago do Janauacá & & 1350,0 & & Lago do Já & & \\
\hline $5^{\circ}$ & Rio Copea & $B$ & 1860,0 & $5^{0}$ & Rio Gamboa & $B$ & 1270,0 \\
\hline
\end{tabular}

Em 2012, a CPUE total de jaraquis foi 37.319 kg por campanha de pesca, e a média mensal de $3.109,908 \mathrm{~kg} /$ campanha (Tabela 5). No ano de 2013, a CPUE total foi de $37.142 \mathrm{~kg}$ por campanha de pescado, e a média mensal da CPUE da ordem de 3.095,158 kg/ campanha (Tabela 6). Dessa forma, valores para CPUE foram inferiores nesse último ano, tanto nos valores totais quanto nas médias mensais. $O$ fator que fez a pesca ser mais eficiente no ano de 2012, pode estar ligado a grande cheia, porém este fator só poderia ser testado se fossem analisados um número maior de anos.

A produção total desse pescado no ano de 2012 foi de $4.085 .700 \mathrm{~kg}$, com média de $340.475 \mathrm{~kg}$ por mês, sendo o maior volume de produção em abril $(827.600 \mathrm{~kg}$ ) e o menor em julho (8.600 kg). Já em 2013, a produção total do jaraqui foi de $4.913 .590 \mathrm{~kg}$, com média de $409465,8 \mathrm{~kg}$, sendo o maior volume de produção em abril e maio, onde obtiveram o mesmo valor $(1.128 .300 \mathrm{~kg})$ e o menor em julho (68.540 kg) (Tabela 6). A coincidência dos meses de maior e menor produção de jaraqui em ambos os anos indicam o período de safra e entressafra da espécie. 
Tabela 5. Captura por unidade de esforço (CPUE), esforço (número de barcos) e produção em quilogramas por meses do ano de 2012

\begin{tabular}{lcll}
\hline Mês/Ano & № de Barco de pesca & Pescado $\mathbf{( k g )}$ & CPUE \\
\hline Janeiro & 127 & 745.600 & 5870,9 \\
Fevereiro & 46 & 130.200 & 2830,4 \\
Março & 106 & 474.700 & 4478,3 \\
Abril & 212 & 827.600 & 3903,8 \\
Maio & 197 & 540.850 & 2745,4 \\
Junho & 99 & 199.500 & 2015,2 \\
Julho & 4 & 8.600 & 2150,0 \\
Agosto & 58 & 100.500 & 1732,8 \\
Setembro & 56 & 131.400 & 2346,4 \\
Outubro & 64 & 146.250 & 2285,2 \\
Novembro & 85 & 257.200 & 3025,9 \\
Dezembro & 133 & 523.300 & 3934,6 \\
Total & 1187 & 4.085 .700 & 37319 \\
Média & 98,9166667 & 340.475 & 3109,908 \\
\hline
\end{tabular}

Tabela 6. Captura por unidade de esforço (CPUE), esforço (número de barcos) e produção em quilogramas por meses do ano de 2013

\begin{tabular}{llll}
\hline Mês/Ano & № de Barco de pesca & Kg pescado & CPUE \\
\hline Janeiro de 2013 & 103 & 68.540 & 665,4 \\
Fevereiro de 2013 & 45 & 142.400 & 3164,4 \\
Março de 2013 & 124 & 585.800 & 4724,2 \\
Abril de 2013 & 241 & 1.128 .300 & 4681,7 \\
Maio de 2013 & 308 & 1.128 .300 & 3663,3 \\
Junho de 2013 & 157 & 346.300 & 2205,7 \\
Julho de 2013 & 59 & 123.500 & 2093,2 \\
Agosto de 2013 & 58 & 145.600 & 2510,3 \\
Setembro de 2013 & 70 & 187.600 & 2680,0 \\
Outubro de 2013 & 93 & 302.500 & 3252,7 \\
Novembro de 2013 & 133 & 508.200 & 3821,1 \\
Dezembro de 2013 & 67 & 246.550 & 3679,9 \\
Total & 1458 & 4.913 .590 & 37142 \\
Média & 121,5 & $409.465,8333$ & 3095,158 \\
\hline
\end{tabular}

Em 2013, ano mais dentro do padrão no que diz respeito aos níveis do rio, a captura do jaraqui se torna mais constante em relação à 2012. As capturas de peixe apresentaram um caráter sazonal com valores mais altos no período de enchente e cheia (GONÇALVES et al. 2020). Os níveis de produção nos dois principais rios foram maiores no ano de 2013 do que em 2012. No estudo feito por Silva 
(2017) para produção pesqueira total, observou-se um padrão para a somatória de espécies que foram desembarcadas em Manaus nesse mesmo intervalo de anos. Esta autora mencionou que provavelmente este fato foi influenciado pela cheia histórica de 2012, que ocorreu nesse trecho da bacia Amazônica, de forma que o aumento do nível do rio disponibilizou mais alimento e abrigo para os peixes, o que se refletiu no aumento dos valores de produção nos anos seguintes. Já de acordo com Guerreiro et al (2020), anos com grande amplitude de inundação impactam negativamente o crescimento do jaraqui nos dois anos seguintes, porém uma sequência de anos de La Niña, aparentemente, ajudam na redução da mortalidade de pesca, colaborando para sua recuperação.

De acordo com a estimativa do tamanho do estoque feita por Silva Jr., (2017), esta espécie tem o tamanho maior, da ordem de $128.748 .362 \mathrm{~kg}$. Estes grandes valores têm sustentado as pescarias e garantido a segurança alimentar da população. Nesse mesmo estudo, a captura média anual foi de 9.382.587kg para Amazônia, quando comparamos com os valores anuais dos referidos anos, verificamos que grande parte do total de jaraquis da Amazônia se destina à Manaus.

A maior CPUE ocorreu em janeiro em 2012 e em março de 2013, correspondendo ao período de enchente, e os menores valores ocorrem em agosto de 2012 e em julho de 2013 (Figura 2 e 3), correspondente a vazante e cheia, de uma forma geral adotando um padrão inverso ao nível do rio. Variações temporais na produtividade podem estar associadas a vários fatores, desde aqueles que influenciam os processos migratórios, passando pelo nível do rio no momento da pescaria, quanto ao local de pesca escolhido. De acordo com Dias-Neto (2015) a espécie realiza migrações no início da enchente e nas cheias, tornando-as mais acessíveis à captura. A redução na eficiência da pescaria durante a enchente e cheia, está relacionado ao fato das espécies estarem dispersas em grande quantidade de água (CORRÊA et al.2018).

Os picos de CPUE podem ter sido ocasionados por ter ocorrido em 2011 e 2012, atraso nos pagamentos do seguro defeso, que protege algumas espécies nos períodos de 15 de novembro a 15 de março (JUSBRASIL, 2012). Isto pode ter impulsionado os pescadores a atuar ainda mais, inclusive em época proibida, o que pode explicar o pico de janeiro e julho, pois até essa a data os pescadores ainda não tinham recebido. O aumento da CPUE do jaraqui nessa época, pode estar associado ao déficit de outras espécies ou as proibições da sua captura no defeso, no qual o jaraqui não tinha sido contemplado durante os anos analisados. Esta suposição concordaria com o descrito por Ribeiro e Petrere Jr (1990), que consideram que a pesca do jaraqui compensa a redução na captura de espécies maiores. 
Matos (2020), em seu estudo que engloba o total de espécies desembarcadas para os anos de19761999, verificou maior CPUE em dezembro (seca), se diferenciando deste, onde se observa maiores valores na enchente e cheia. Nosso estudo também concorda com Silva (2017), que encontrou para os desembarques da mesma época do presente estudo, para a cidade de Manaus, envolvendo todas as espécies, um maior valor de CPUE na cheia e o menor da seca.

O segundo pico, referente a julho não é esperado, uma vez que os níveis do rio ainda estão bem altos no ano correspondente ao da cheia histórica, e altas cotas fluviais, em geral, tornam a pesca mais difícil. Este fato pode estar associado ao favorecimento de uso de aparelhos de alta capturabilidade como a rede de cerco, muito utilizada na pesca do jaraqui (SOUZA Jr. 2018), uma vez que o nível de água alto, evita o enredamento do aparelho em galhos e pedras, ou pode estar associado também a movimentos migratórios que tornam a espécie mais vulnerável por formar grandes cardumes.

7000,0

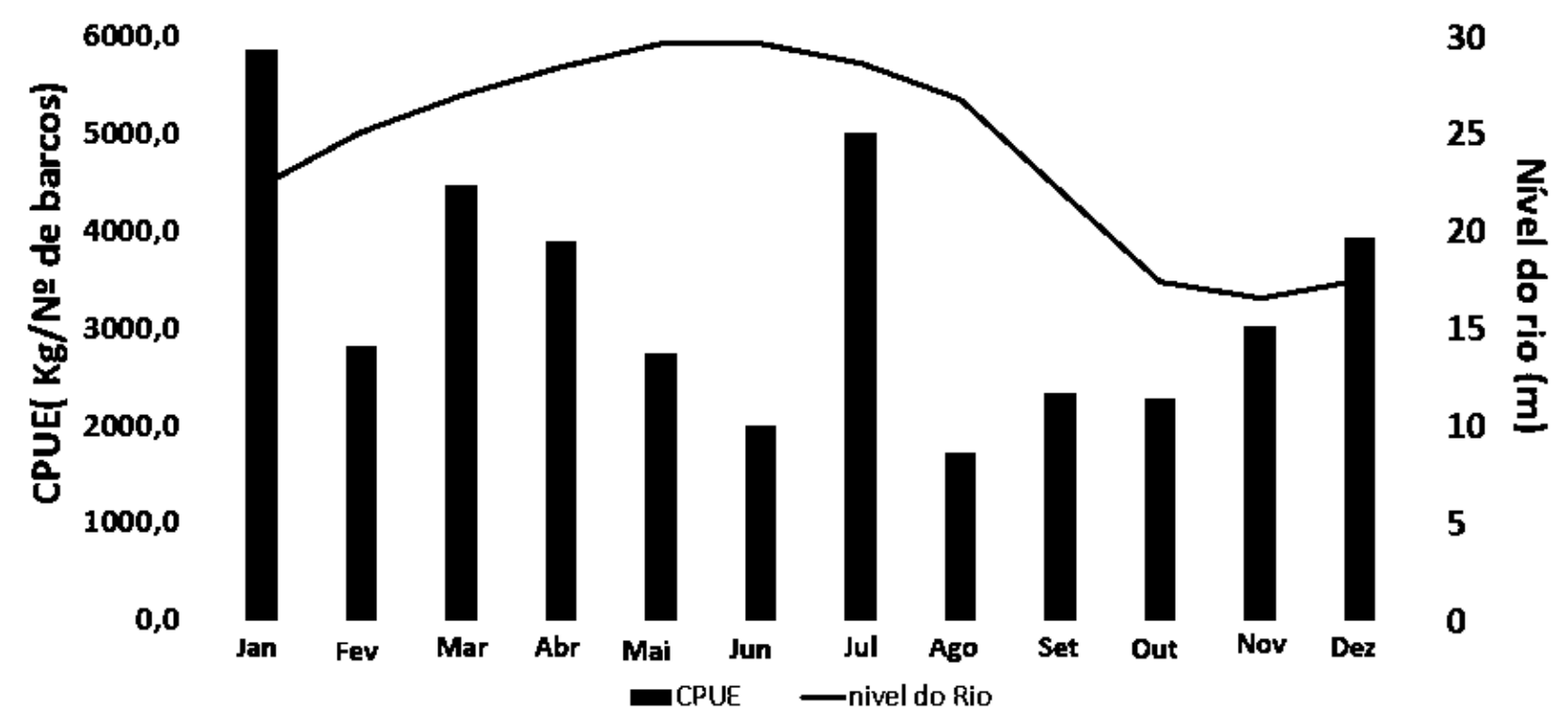

Figura 2: Oscilação da CPUE ( $\mathrm{kg} / \mathrm{n}^{\circ}$ barcos) de acordo com o ciclo hidrológico no ano de 2012 


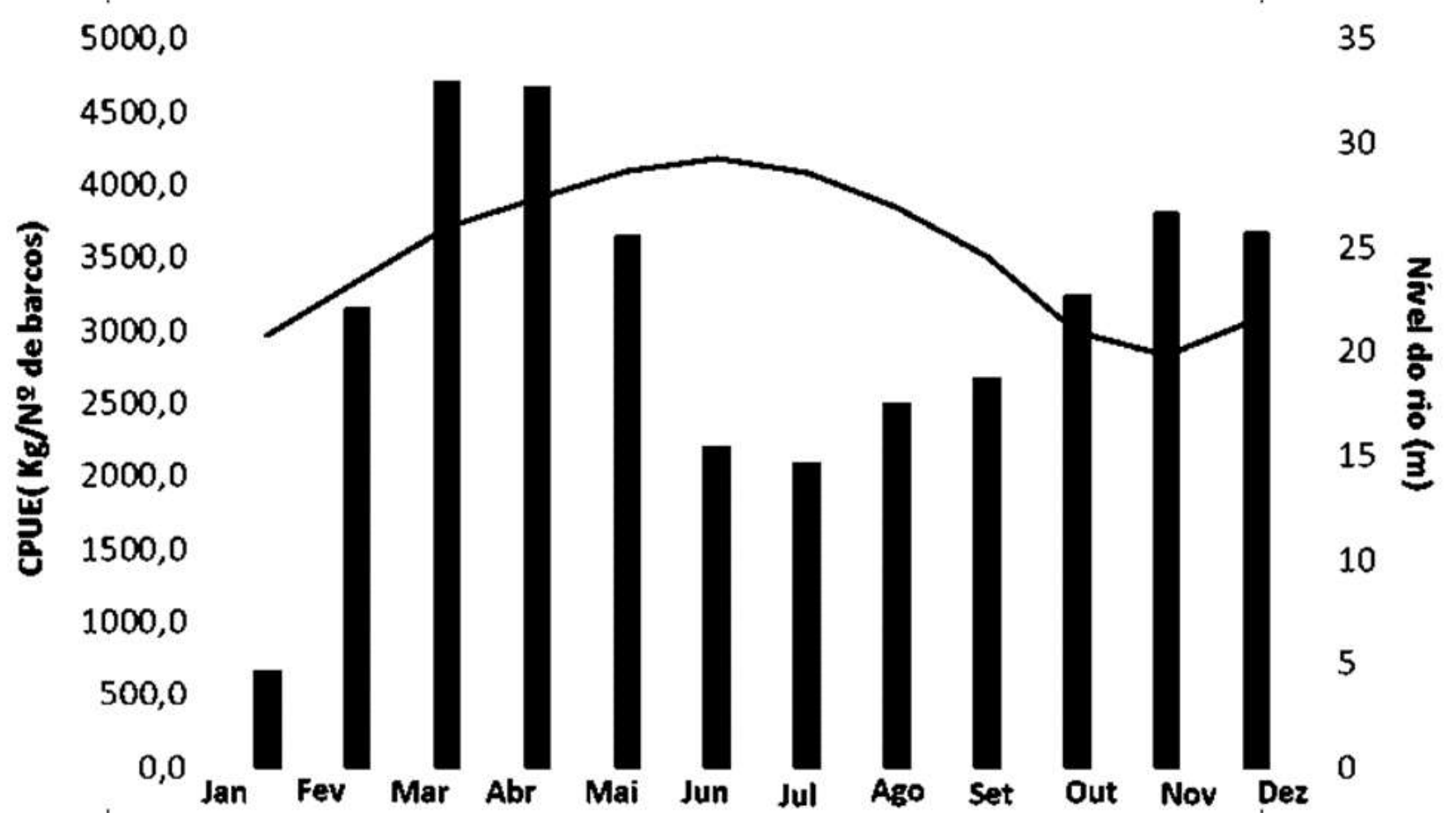

Figura 3: Oscilação da CPUE (kg/nºbarcos) de acordo com o ciclo hidrológico no ano de 2013

O jaraqui apresenta um roteiro migratório complexo que começa no início da enchente e terminam na vazante (GUERREIRO et al 2020. VALÉRIO JR. 2019, SOARES 2017), tornando essa espécie vulnerável à pesca durante muitos meses, por causa da formação de grandes cardumes. O período de maior CPUE e produção, coincidem com o período que ocorrem as migrações da espécie Semaprochilodus spp, o que contribui para maior vulnerabilidade desses estoques, porém o sucesso na pescaria também é fruto da falta de defeso reprodutivo para essa espécie, que somente voltou à lista de defeso no ano de 2015. Este fato deixa essa espécie já apontada como sobrepescada e ainda mais suscetível a elevados esforços.

\section{CONCLUSÃO}

Os valores de CPUE do jaraqui variaram ao longo do ciclo hidrológico, atingindo o ápice no período de enchente e cheia e menores valores na vazante.

Em 2012, ano da extrema cheia, o pico do nível do rio coincidiu com uma queda no valor da CPUE do jaraqui.

A produção do Jaraqui alcança seu ápice durante enchente e cheia.

A produção do jaraqui é oriunda de vários rios e lagos diferentes quanto às suas características, o que se reflete na sua produtividade. 
Os rios que apresentaram maiores médias de produção do jaraqui são em sua maioria de água branca, como o Tefé, o Tapauá, Ipixuna e o Jutaí. 


\section{REFERÊNCIAS:}

ALI, Z. \& BHASKAR, S.B Ferramentas estatísticas básicas em pesquisa e análise de dados. Indian Journal of Anesthesia, 60 (9), 662. 2016.

BITTENCOURT, M. M. Aspectos da demografia e do ciclo de vida de Pygocentrus natterei Kner, 1860 num lago de várzea da Amazônia central (Lago do Rei-Ilha do Careiro). Tese de Doutorado. Instituto Nacional de Pesquisas da Amazônia.1994.

CAD. S. V. A produção pesqueira e o esforço da pesca no município de Manaus (Amazonas-Brasil): análise e proposta de melhorias para viabilizar a industrialização. Dissertação. Programa de PósGraduação em Engenharia de Produção. UFAM. 65p. 2017.

CPRM - Companhia de Pesquisa de Recursos Minerais. Relatório da Cheia de 2012. DHT- Diretoria de Hidrologia e Gestão Territorial. DEHID - Departamento de Hidrologia. Disponível em <http://www. cprm.gov.br>. Acesso em: 04 jan. 2017. 2012.

CORRÊA, M. A.A; NASCIMENTO, S. C. B.; SONODA, D. Y.; SOUZA, L. A. A produção e a receita pesqueira como indicadores econômicos da pesca artesanal na Amazônia Central. Revista Ciências Da Sociedade, 2(4), 13-31.2018.

CPRM - Companhia de Pesquisa de Recursos Minerais. DHT- Diretoria de Hidrologia e Gestão Territorial. DEHID - Departamento de Hidrologia. SUREG-M- Unidade Regional. Relatório da Cheia de 2012. Disponível em <http://www. cprm.gov.br>. Acesso em: 04 jan. 2017.

DIAS-NETO, J. O uso da biodiversidade aquática no Brasil: uma avaliação com foco na pesca. Brasília: IBAMA, 2015. $288 p$

FARIA JR, C. H.; BATISTA, V.S. Frota pesqueira comercial na Amazônia Central: composição, origem, espécies exploradas e mercado. Revista Agroecossistemas, [S.I.], v. 11, n. 1, p. 146-168, dez. 2019.

FISHER, T. R. Plâncton e produção primária em sistemas aquáticos da bacia da Amazônia Central. Acta Amazonica, v. 8, n. 4, p. 43-54, 1978.

FROTA, A. J. Entre rios e a cidade: os flutuantes de Tapauá No Amazonas. $2017157 \mathrm{~F}$

GOMES, K. F. A. Efeito da conexão de lagos de várzea com o Rio Solimões sobre a diversidade de peixes. Dissertação PPG CIPET, Universidade Federal do Amazonas 2016.

GONÇALVES, V. V. C.; SANTOS, J. A.; FREITAS, C. E.C. Seasonal and spatial dynamic of small scale fisheries in Central Amazonia. Terceira Margem Amazônia, 6 (15). 2020.

GUERREIRO, A. I. C. Influência de extremos de cheia e de seca nos recursos capturados pela pesca comercial desembarcados no porto de Manaus (Amazonas, Brasil).111 p. Tese. BADPI - INPA, Manaus, 2017.

GUERREIRO, A. I. C.; AMADIO, S. A.; FABRÉ, N. N.; BATISTA, V.S. Exploring the effect of strong hydrological droughts and floods on populational parameters of Semaprochilodus insignis (Actinopterygii: Prochilodontidae) from the Central Amazonia. Environment, Development and Sustainability, 1-11. 2020. 
JUNK, W. J. Aquatic habitats in Amazonia. Environmentalist, v. 3, n. 5, p. 24-34, 1983.

JUSBRASIL. MPF/AM garante na Justiça pagamento do seguro defeso a pescadores profissionais..https://pr-am.jusbrasil.com.br/noticias/3125146/mpf-am-garante-na-justicapagamento-do-seguro-defeso-a-pescadores-profissionais. Acessado em fevereiro de 2021. 2012.

LOPES, G. C. S.; CATARINO, M. F.; LIMA, Á. C.; FREITAS, C. E. C. A pesca de pequena escala na Bacia Amazônica: padrões gerais e diversidade pelos desembarques de cinco sub-bacias. Boletim do Instituto de Pesca, 42(4), 889-900. 2017.

LOPES, G. C.S.; SOUZA, L. A.; INOMATA, S. O. Modelagem das inter-relações entre a pesca e o regime fluvial no Rio Purus, AM. Revista Brasileira de Engenharia de Pesca, v. 10, n. 2, p. 94-112, 2017.

MATOS, O. F. D. Avaliação do efeito da pesca nos estoques pesqueiros da Amazônia Central. Dissertação PPG CIPET, Universidade Federal do Amazonas 2020. 121p.

NASCIMENTO, S.C.B. Modelagem da Produção Referente à Piscicultura e a Pesca Comercial Artesanal que Abastece a Cidade de Manaus - Amazonas. Dissertação. Programa de Pós-Graduação em Engenharia de Produção. UFAM. 75p. 2017.

PEREIRA, D. V. Componentes da paisagem e o rendimento pesqueiro na várzea amazônica. Dissertação de Mestrado. CIPET-UFAM. 50p. 2020.

PONTE, S.C.S.; OLIVEIRA, L.S. e ZACARDI, D.M. Variação temporal de larvas de peixes de um lago de inundação como subsídio à gestão ambiental. Journal of Applied Hydro-Environment and Climate 1(1): 1-13. 2019.

RIBEIRO, M. C. L. B; PETRERE Jr., M. Fisheries ecololgy and management of the Jaraqui (Semaprochilodus Taeniurus, S. Insignis) in central Amazonia. Regulated Rivers: Research \& Management, v. 5, n. 3, p. 195-215, 1990.

SILVA, A. C. S.; GONÇALVES, V. V. C. G.; FRAXE, T.J. P.; AMORIM, R. M. S.; GONZAGA Jr, M.G.; XIMENES, A.M. Avaliação do desembarque pesqueiro (2016-2017) no Município De Lábrea, Amazonas, Brasil Congresso Brasileiro De Engenharia De Pesca - XXI CONBEP. 21 a 24 de outubro de 2019 Manaus (Am) - a capital brasileira da pesca e da aquicultura 10p.

SILVA JR., U. L.; RASEIRA, M. B.; BATISTA, V.S.; RUFFINO, M. L Estimativa do tamanho de estoques pesqueiros da Amazônia baseada em dados de captura e esforço. Biodiversidade Brasileira-BioBrasil, n. 1, p. 105-121, 2017.

SILVA, G. T.; SOUZA, F. C. B. Turismo de base comunitária e sustentabilidade. Terceira Margem Amazônia, v. 2, n. 8, 2017.

SILVA, S.N. 2017. Produção pesqueira e esforço de pesca do município de Manaus. Universidade Federal Do Amazonas. FCA. DEPESCA. 2017. 30p.

SOARES, N. D. N. Influência do Rio Negro e Solimões para a contribuição das fontes autotróficas de energia do Semaprochilodus insignis. Dissertação PPG CIPET, Universidade Federal do Amazonas 2017. 
SOUZA JR, M. T. D. S.Redes de pesca empregadas pelos pescadores comerciais na Costa Do Canabuóca, Manacapuru - Am: caracterização, técnicas e eficiência de captura. Dissertação PPG CIPET, Universidade Federal do Amazonas. 76p. 2018.

SPARRE, P.; VENEMA, S.C. Introdução à avaliação de mananciais de peixes tropicais. Parte 1: Manual. FAO Documento Técnico sobra as Pescas. No. 306/1, Rev.2. Roma, FAO. 404p. 1997.

VALÉRIO JR, J. F.; DIAS, C. R. G.; SILVA, A. P. Relação peso-comprimento, fator de condição do jaraqui Semaprochilodus brama (Valenciennes, 1850) e sua importância para a pesca no rio Araguaia, Brasil. Anais do Congresso Brasileiro de Engenharia de Pesca. 2019. 10p. 


\section{Capítulo 5}

\section{doi $10.37423 / 210904738$}

\section{VARIAÇÃO SAZONAL DO CONSUMO PROTEICO ANIMAL NA REBIO ABUFARI (TAPAUÁ/AMAZONAS)}

Adailson Freire dos Santos

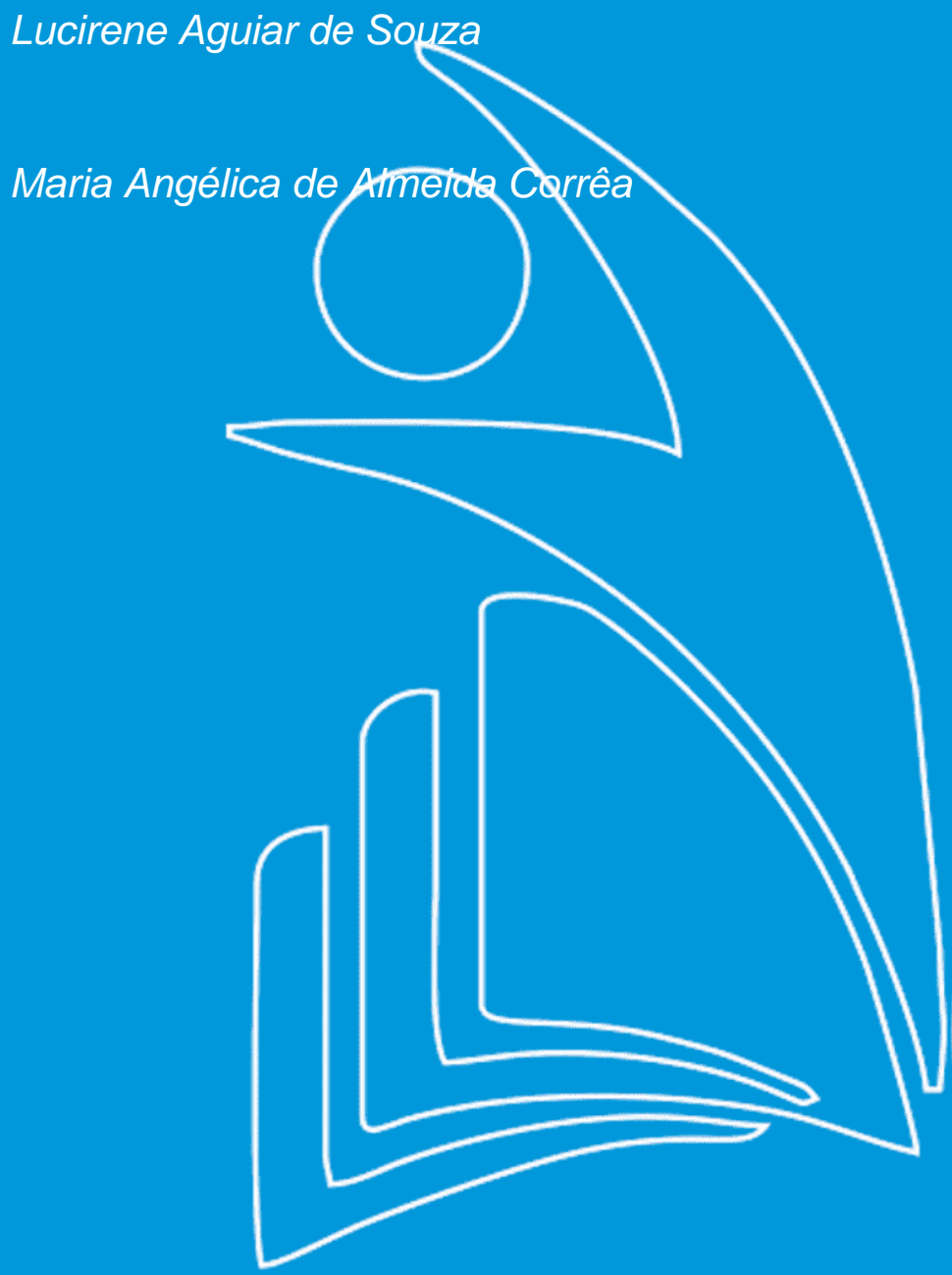

Engenheiro de Pesca, Universidade Federal do Amazonas

Doutora em Biologia de Água Doce e Pesca Interior, Professora Asseciada da FCAVUFAM

Doutora em fêencjas pesquairas nos

Trópicos Professor Adjunta de Faculdade de Ciêplcias Agráriał

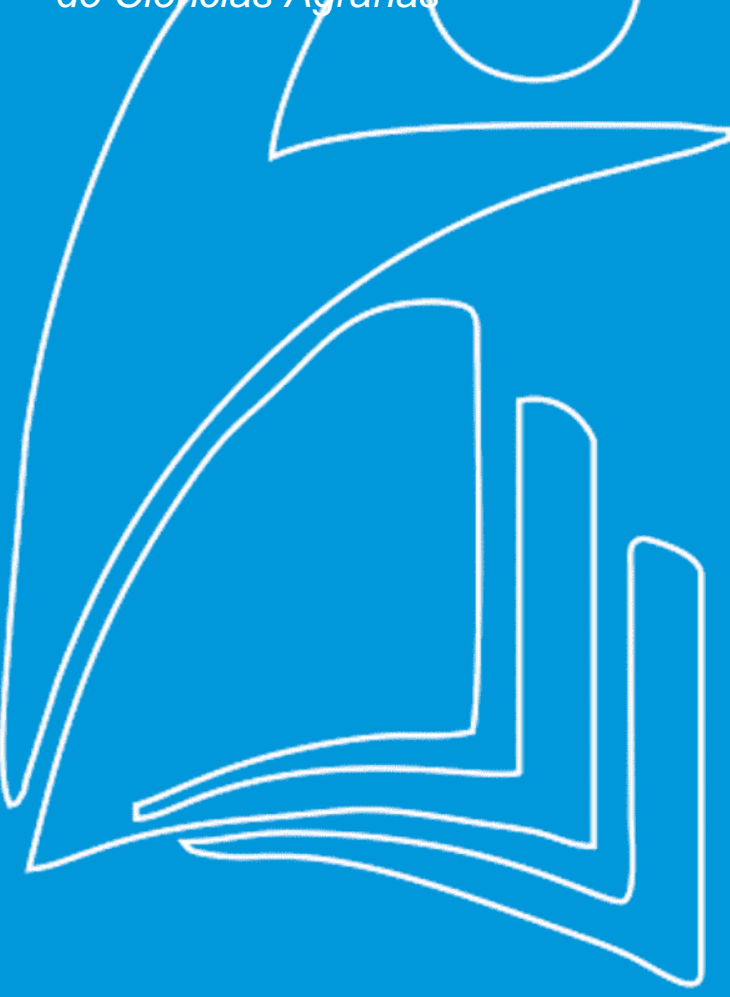


Resumo: A alimentação da população ribeirinha está inteiramente ligada ao ciclo hidrológico. Baseado nesse contexto, o presente trabalho teve por objetivo avaliar as fontes de proteína animal consumidas pelos moradores da Reserva Biológica Abufari (Rebio Abufari) no município de Tapauá, AM, e sua variação de acordo com as fases do pulso de inundação. A coleta de dados foi feita através de questionário estruturado, aplicados durante o período de seca do ano de 2018 e de 2019 . Foi feita a análise descritiva dos parâmetros, relacionando o consumo proteico animal dos moradores ao período da cheia e da seca dos rios. As fontes de proteína citadas, em ordem de importância, derivaram do pescado, das aves, da caça, dos bovinos e dos suínos. O pescado apresentou maior frequência de consumo como fonte de proteína, sendo consumido todos os dias no período da cheia e da seca por 73\%, e $77 \%$ dos entrevistados, respectivamente. As outras fontes proteicas foram pouco citadas. Apesar de proibida, há incidência de caça na REBIO.

Palavras - Chave: Ciclo hidrológico; Proteína animal; Alimentação ribeirinha. 


\section{INTRODUÇÃO}

As variações sazonais têm afetado as formas de obtenção de alimento de diversos povos (BETTINGER et al., 2015, VASCONCELOS NETO, 2016). Na região amazônica não é diferente, e desta forma o modo de vida, particularmente dos ribeirinhos, está muito associada a flutuação dos níveis dos rios (VASCONCELOS NETO, 2016).

Os efeitos dessa variação na produção pesqueira e agrícola já foram estudados na região amazônica (MONTENEGRO e SOUZA, 2016; GONÇALVES, 2018; LOUZADA, 2019; SILVA et al, 2020), devido a sua grande importância para a subsistência dos povos da região. Por outro lado, há poucos estudos dessa influência sobre a caça, mas estes apontam efeitos da sazonalidade sobre a mesma (VALSECCHI et al., 2014; MORCATTY e VALSECCHI, 2015). Conhecer os efeitos da variação do nível dos rios sobre as formas de obtenção de proteína pelas populações ribeirinhas é cada vez mais importante, uma vez que ao longo dos anos vimos observando o aumento da predominância de cheias extremas e secas severas que afetam seus modos de vida (FREITAS, 2016; RAMOS, 2016).

Estudos sobre as formas de alimentação das populações e do acesso aos alimentos podem nos mostrar os impactos causados pelos eventos naturais, sobretudo, dentro de Unidades de Conservação. Isso nos leva a considerar que uma possível escassez poderá incentivar a exploração indevida nessas áreas protegidas. Nesse contexto, este estudo analisou a frequência do consumo de proteína em função dos níveis do rio na REBIO Abufari, no estado do Amazonas

\section{MÉTODOS}

\section{ÁREA DE ESTUDO}

A Reserva Biológica do Abufari (Figura 1) está localizada em uma região de várzea, às margens do rio Purus e do rio Madeira, no município de Tapauá. Esta Unidade de Conservação tem 233.864,64 ha de área (ICMbio, 2017). Ela abriga cerca de 1.466 pessoas, com uma densidade populacional de 0,5 hab/km, (IBGE, 2007). Foi criada no ano de 1992 através de Decreto № 87.585, de 20 de setembro de 1982 (BRASIL, 1982), com o intuito de preservação da área principal de reprodução da Tartaruga da Amazônia (Podocnemis expansa), (ANDRADE,1981), proteção de espécies comerciais de peixes ameaçadas de extinção, incentivar o desenvolvimento científico, proporcionar educação ambiental aos moradores, sempre respeitando suas culturas e tradições (ICMBio, 2012). 


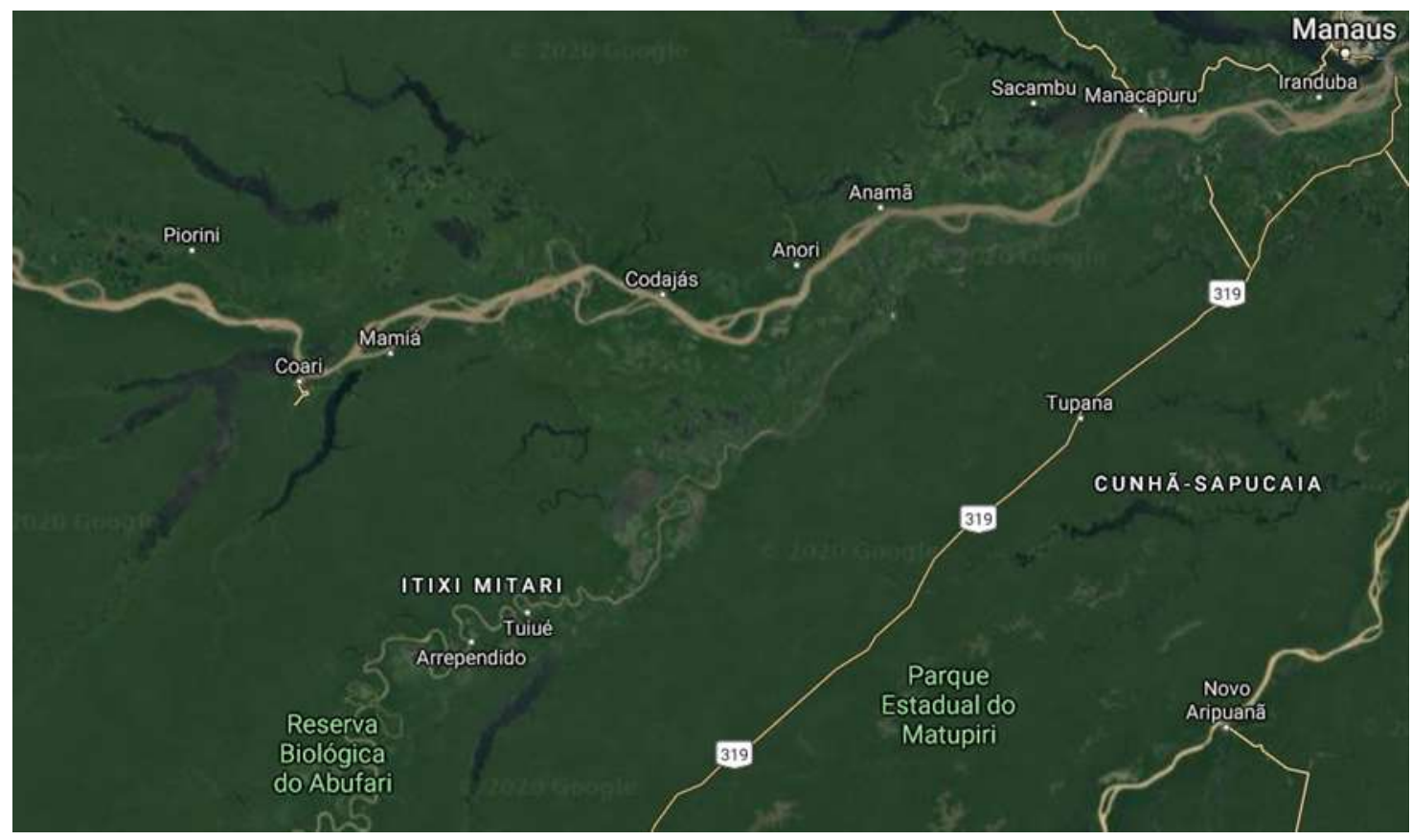

Figura 1: Mapa da área de estudo: REBIO Abufari ( $5^{\circ} 14^{\prime} 13^{\prime \prime} \mathrm{S} 63^{\circ}$ e $\left.3^{\prime} 48^{\prime \prime} \mathrm{O}\right)$

\section{COLETA DE DADOS}

Os dados que compõem os parâmetros analisados foram obtidos do Banco de Dados Socioeconômico do projeto "Diversidade de peixes em resposta a diferentes tipos de manejo em áreas alagáveis da Amazônia: aspectos ecológicos e socioeconômicos", do Programa de Pesquisa Ecológica de Longa Duração (PELD). Os dados, por sua vez, foram coletados por meio de questionários semiestruturados, nos anos de 2018 no período da vazante (agosto), e de 2019 no período da enchente (fevereiro) dos rios. Três comunidades participaram da pesquisa, sendo elas: Tambaquizinho, Fazenda e Pupunha. As unidades amostrais são as famílias (48), e os respondentes dos questionários são as pessoas de referência, acima de 18 anos.

\section{ANÁLISE DOS DADOS}

Foi feita a análise descritiva dos parâmetros relacionados ao consumo proteico, variáveis sociais e econômicas dos entrevistados, durante o período da seca e da cheia. Estes períodos marcam o fim das atividades produtivas, realizadas com intensidade nos períodos antecedentes de vazante e enchente, respectivamente, durante o ciclo hidrológico. 


\section{RESULTADOS E DISCUSSÃO}

Segundo Lira e Chaves (2016), a variação do nível dos rios possui grande efeito na vida das populações amazônicas. As atividades praticadas dentro da REBIO Abufari têm influência direta nas questões sociais, culturais e sazonais, tendo como foco atividade da pesca, da caça e do extrativismo (SANTOS, 2019). O consumo diário de proteína a base de pescado nos períodos analisados, tanto na cheia quanto na seca, foi elevado dentre as famílias da UC, as a quais citaram consumir pescado todos os dias (Figura 2). Situação semelhante, de consumo diário, não é observado para nenhuma das outras fontes proteicas testadas. Segundo Souza (2003) nas Ilhas da Paciência e do Baixio (Iranduba, AM), o consumo dos moradores é menos frequente comparado aos dos moradores da REBIO Abufari $(4,3$ para 5,3 dias, respectivamente). Provavelmente, pelo fato de que nas áreas de várzea, sem proteção integral, existe o incentivo econômico para a criação de animais de pequeno e médio portes, ampliando o acesso à outras proteínas diversificadas, enquanto o mesmo não é permitido aos moradores de reservas biológicas.

Os altos valores de consumo de proteína de pescado já foram observados em várias regiões da Amazônia (SHRIMPTON e GIULIANO, 1979; AMOROSO, 1981; BATISTA et al., 2000). Souza (2003) observou um aumento no consumo de pescado no período da cheia nas ilhas do município de Iranduba, AM, visto que a diminuição do consumo de caça ou de animais de criação, por conta da alagação das faixas de terra.

A proteína de aves aparece como a segunda fonte de acesso dos moradores da reserva, com consumo de 2 a 3 vezes por semana, tanto no período da cheia (36\%) quanto no período da seca (44\%), mas, por outro lado, a maioria das citações indica o raro o consumo nas duas fases do ciclo hidrológico (Figura 3). As aves são animais de pequeno porte e são mais facilmente criadas pelos moradores para seu consumo. A pequena diferença observada entre os períodos pode ser justificada pela necessidade de abater e consumir a proteína no período da enchente, antes da subida das águas.

A carne de caça foi observada como a terceira mais utilizada na área de estudo, sendo mais frequentemente citada como consumo raro, destacando-se no período da seca (Figura 4). Dependendo do ciclo fluvial, comportamento dos animais se adaptam propiciando determinados tipos de caça. No caso das águas altas, os animais terrestres são ameaçados pela contração da faixa de terra (JUNK, 1983), facilitando a sua captura. 


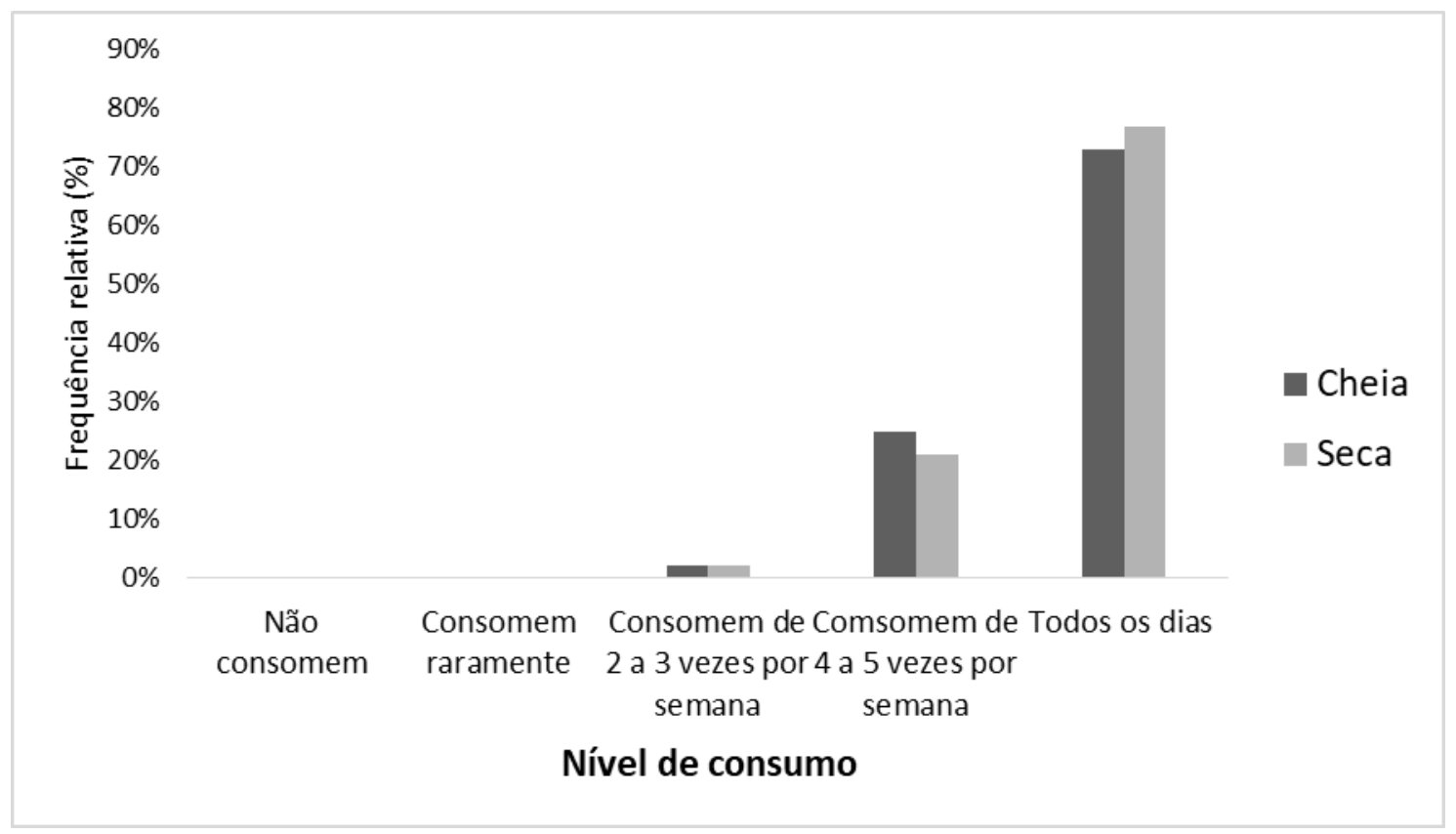

Figura 2: Frequência relativa do consumo de peixes na cheia e na seca na área de estudo

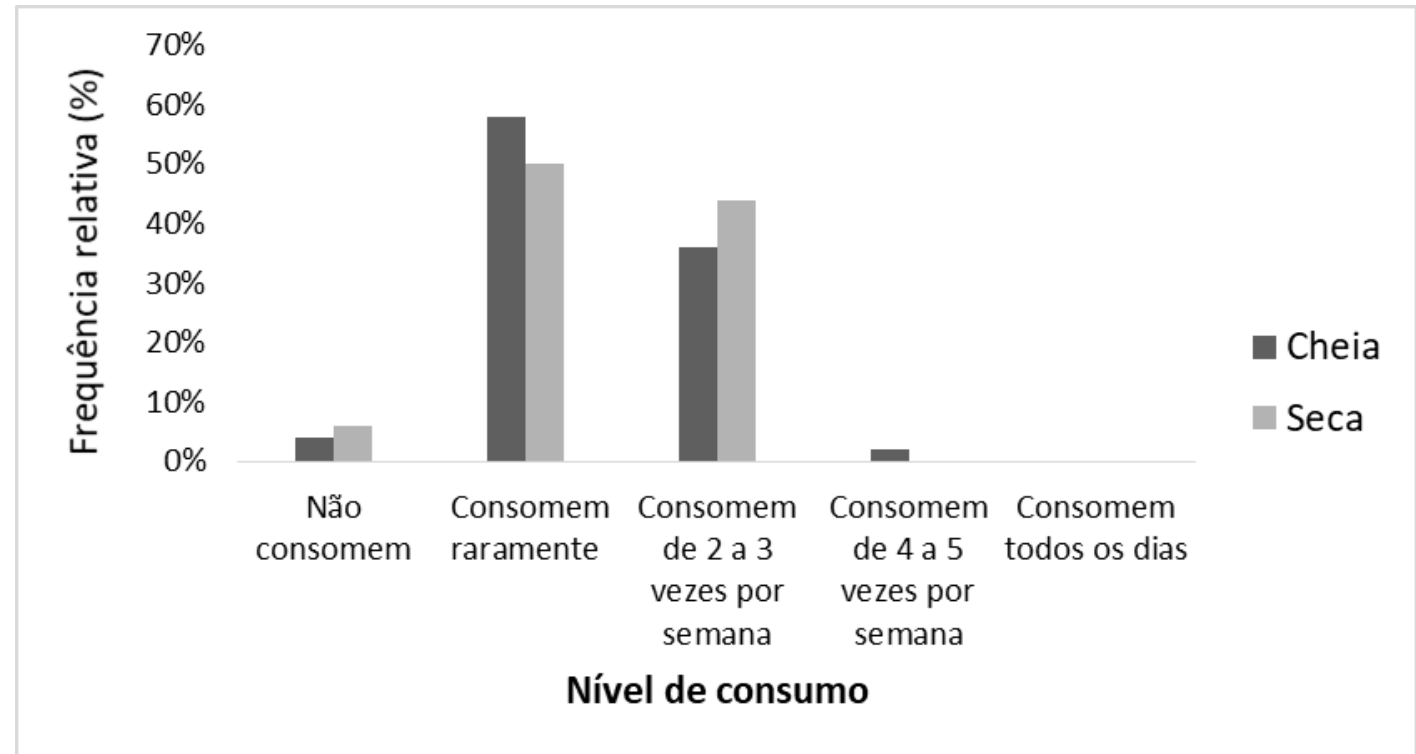

Figura 3: Frequência alimentar de aves durante a cheia e seca na área de estudo 


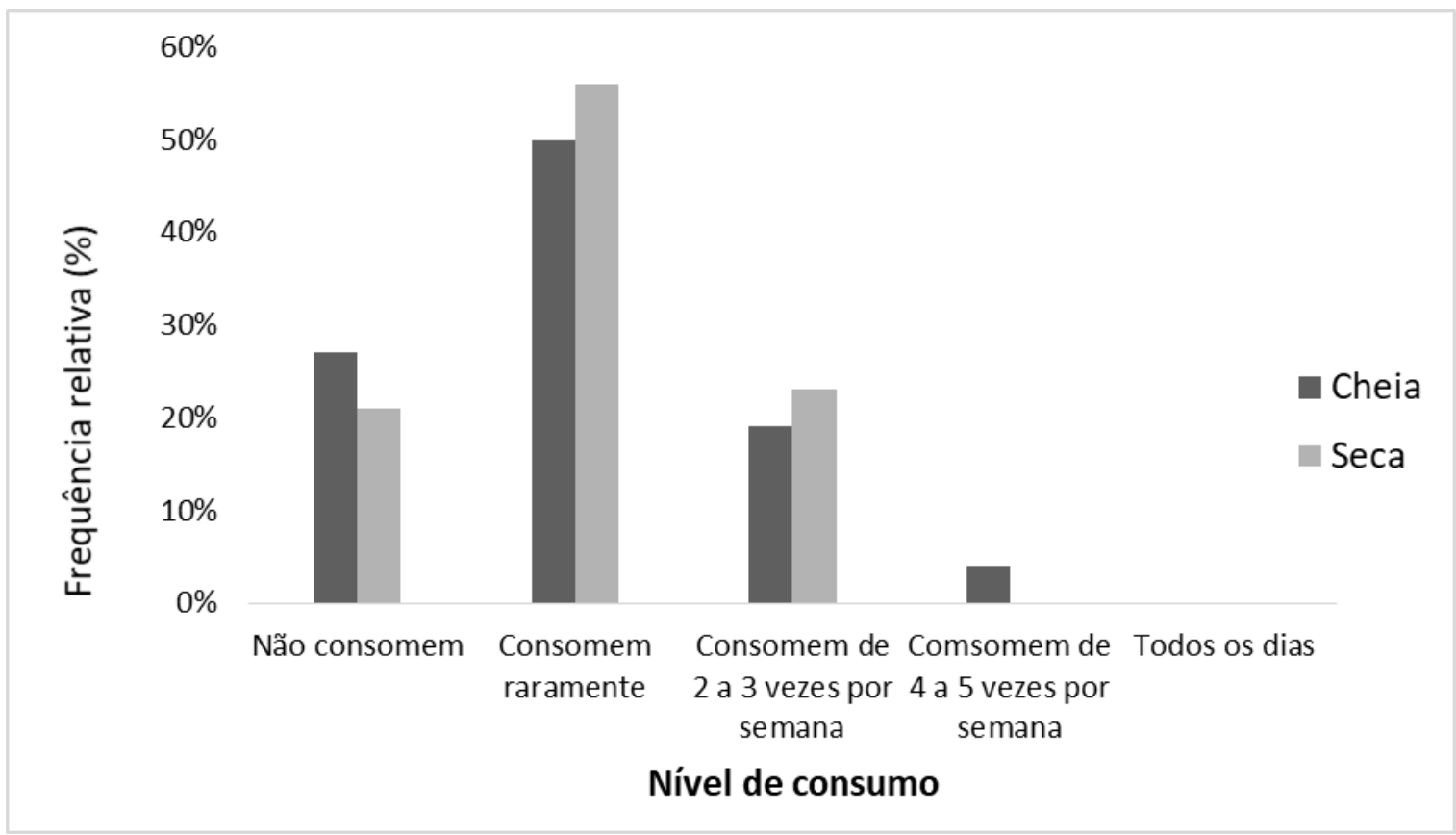

Figura 4: Frequência alimentar de caça durante a cheia e seca na área de estudo

A caça de animais silvestres não é permitida dentro da REBIO Abufari por se tratar de uma reserva biológica. Essa prática é fiscalizada intensamente, para evitar que os moradores abatam animais sob preservação como o caso dos bichos de casco (tartarugas, iaçás, tracajás, etc), além dos jacarés, antas, aves raras, entre outros. Existem espécies de aves ameaçadas de extinção na REBIO Abufari, como o mutum (ICMBio 2014), que á uma das carnes de caça mais apreciadas pelos ribeirinhos da Amazônia. Nessa perspectiva, o consumo da carne de caça dessa região pode ser maior do que o relatado pelos entrevistados, que omitem as informações por medo de represália da parte dos órgãos ambientais de fiscalização. A REBIO Abufari foi considerada a unidade de conservação do Brasil com maior incidência de infrações relacionadas a caça, principalmente em ralação aos répteis, aves e mamíferos (CONSTANTINO, 2019). O relato da prática da caça na REBIO pode levar a conflitos com os gestores da mesma. Conflitos de interesses entre os moradores e os gestores de Unidades de Conservação são comuns ao longo da história do Brasil, onde se preconiza que o uso dos recursos naturais deve ser equilibrado às necessidades socioeconômicos na população local e à preservação da diversidade biológica e sustentabilidade dos usos (BUENO e DAGNINO, 2011).

O consumo de carne bovina. inferior ao de pescado, de aves, e de caça, aparece em quarta colocação, sendo raramente (61\% nos dois períodos) ou não consumida (31 a 35\% nos dois períodos) pelos moradores locais (Figura 5). A soma das respostas de consumo raro ou inexistente ultrapassa 90\%, 
demonstrando o baixo acesso ao produto. No período da cheia há algum consumo de carne bovina, variando de $6 \%$, de 2 a 3 vezes semanais, a $2 \%$, de 4 a 5 vezes por semana.

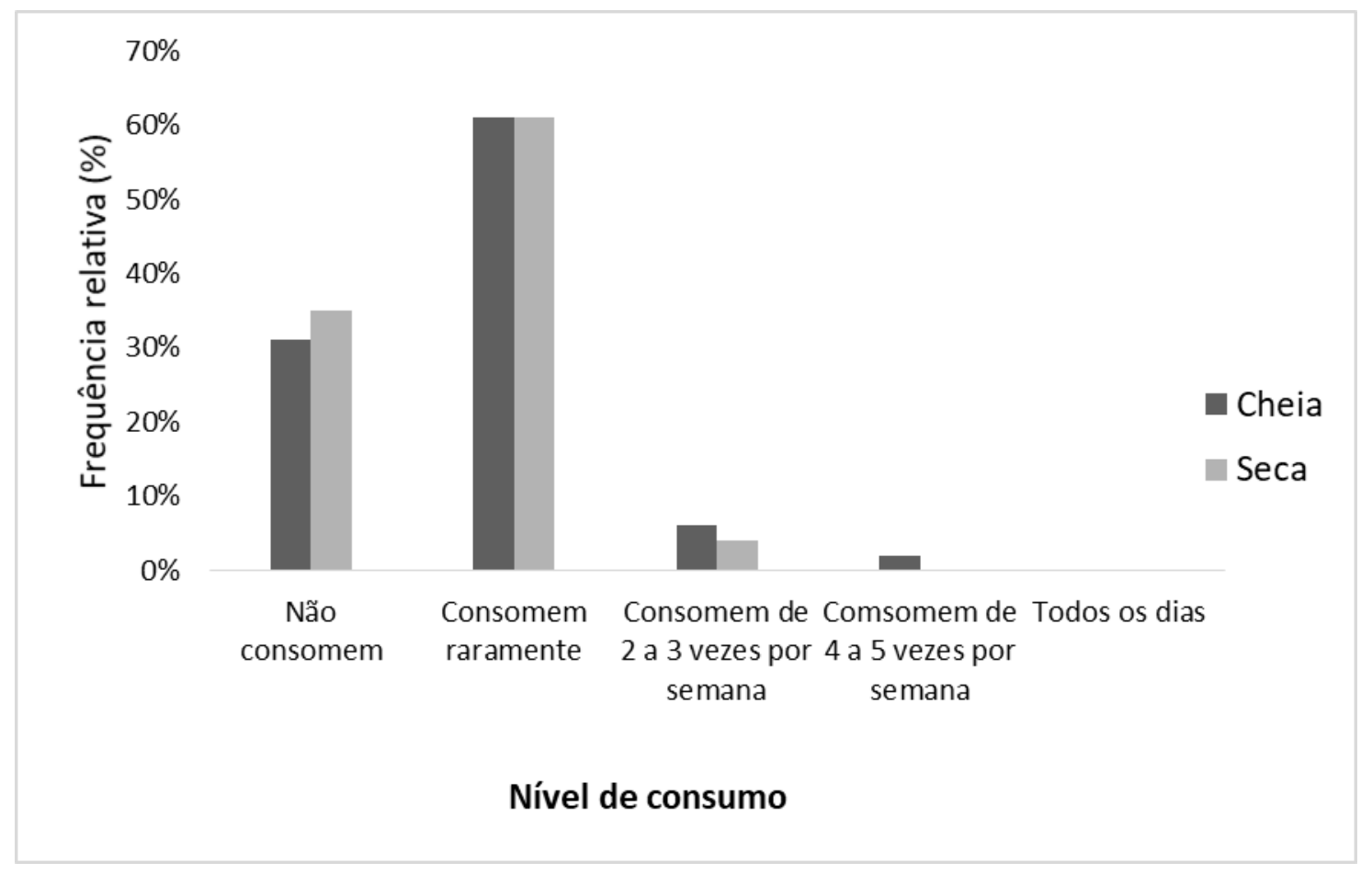

Figura 4: Frequência relativa do consumo de carne bovina no período de seca e cheia pelas famílias da REBIO Abufari

Se considerarmos a inexistência de moradores em reservas de proteção total, como as Reservas Biológicas, é incomum a criação de animais de médio e grande portes. As restrições dessa natureza têm por objetivo a preservação da floresta e da biodiversidade dentro das reservas, mas se houverem moradores locais, essas restrições podem levar à disfunção socioambiental da terra e à insegurança alimentar (SAUER e FRANÇA, 2012). Provavelmente, havendo moradores nas reservas, este tipo de proteína venha de fora da reserva.

O consumo de proteína suína é quase inexistente na REBIO Abufari. Os moradores informaram que não consomem ou raramente consomem proteína suína, restando apenas de 2 a $4 \%$ dos entrevistados que a consome, de 2 a 3 vezes por semana (Figura 5). É provável que a carne suína citada seja procedente de caça, como por exemplo, do porco-do-mato, sendo a queixada (Tayassu pecari) a espécie mais comum (MORAES-ORNELLAS, 2020). O suíno, assim como os animais de médio e grande portes, não tem permissão para serem criados na Reserva Biológica. A carne de porco não é muito apreciada na região amazônica devido a tabus alimentares (BARROS e LOURENÇO-COSTA, 2019). 


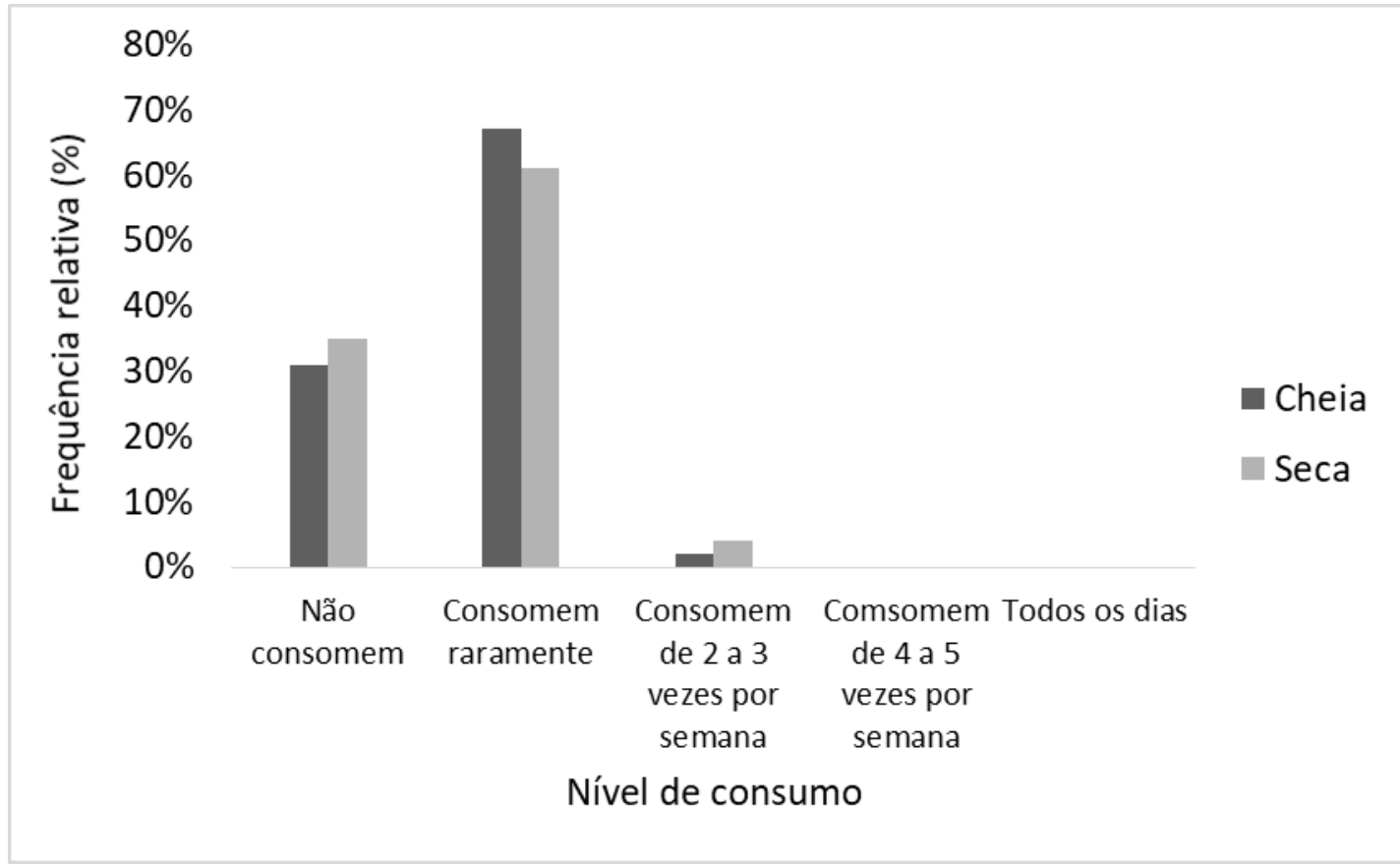

Figura 5: Frequência alimentar do consumo de carne suína na seca pelas famílias da REBIO Abufari A percepção de que os ribeirinhos tem poucos recursos financeiros para comprar a maioria das fontes proteicas citadas, e o fato de ela serem vendidas externamente a REBIO, faz com que se mantenham padrões de consumo tradicionais. De acordo com Nardoto et al. (2011), as alterações nos padrões alimentares dos ribeirinhos estão relacionadas ao acesso aos centros comerciais, que faz com que os amazônidas mudem seu hábito alimentar "tradicional", como o consumo de peixes, por alimentos processados.

Houve pouca variação da cheia para seca nas citações de frequência de consumo de fontes proteicas, com uma maior frequência de citações na seca. Resultado semelhante foi encontrado por Mercado et al (2015), que relatou que cheias agravam situações de insegurança alimentar e nutricional em povos ribeirinhos, em consequência da perda do cultivo alimentar e da contaminação da água, relativamente nos períodos de cheia e seca. A falta de opções de fontes de renda na cheia também contribui para esse quadro (SOUZA, 2003). As escolhas de itens alimentares na região amazônicas são influenciadas por tabus, preferências individuais, fatores ecológicos, sociais e econômicos (SILVA, 2007). Dessa forma, não se pode imputar todas as variações ao ciclo hidrológico, apesar de esse ser um dos fatoreschave que esta correlacionado aos demais fatores. 


\section{CONCLUSÃO}

Existe uma pequena variação entre o consumo de proteína animal na área da REBIO comparando os períodos da cheia e da seca.

As fontes proteicas, na ordem de maior frequência de consumo, são: peixes, aves, caça, bovinos e suínos.

O pescado é a proteína mais abundante nas fases do ciclo hidrológico testadas, restando às demais, sua compra ou caça.

O período da seca é o que fornece maior diversidade de itens de proteína animal. 


\section{REFERÊNCIAS}

AMOROSO, M. C. M. Alimentação em um bairro pobre de Manaus. Acta Amazônica, 3 (11): 1 - 43. 1981.

ANDRADE, G. B. Estudos efetuados para a criação da Reserva Biológica do Abufari - Rio Purus Amazonas. Relatório do projeto Polamazônia, Manaus - AM. 1981.

BARROS, K. S.; CUNHA, R.R.; LOURENÇO-COSTA, V.V. (org.). Alimentação amazônica: guia para pessoas com estomia. Belém: Universidade Federal do Pará, 2019. 38 p. Disponível em: https://livroaberto.ufpa.br/jspui/handle/prefix/844.

BATISTA, V. S.; FREITAS, C. E. C.; SILVA, A. J. I.; FREIRE-BRASIL, D. The fishing activity of the river people in the floodplain of the Central Amazon. p. 417-431. 2000.

BETTINGER, R.L.; GARVEY, R.; TUSHINGHAM, S. (Orgs). Hunter-Gatherers: Archaeological and Evolutionary Theory. Springer, UK. 2015

BRASIL. Decreto № 87.585, de 20 de setembro de 1982. Cria, no Estado do Amazonas, a Reserva Biológica do Abufari. DOU, 22.09.1982.

BUENO, M. D. C. D.; DAGNINO, R. População em Unidades de Conservação da Amazônia Legal: estimativas a partir da Contagem Populacional 2007. Dinâmicas demográficas e ambiente. Campinas: NEPO/Unicamp. 2011. 85-103.

CONSTANTINO, P. A. L. O perfil da caça nas unidades de conservação federais dos biomas brasileiros: um panorama a partir dos autos de infração lavrados pelo ICMBIO. Caça: Subsídios para a Gestão de Unidades de Conservação e o Manejo de Espécies. Biodiversidade Brasileira, v. 9, n. 2, p. 106-129, 2019.

FREITAS, J. S. Modelagem hidrológica e suas variações em função de mudanças climáticas na Amazônia Cntral (Trabalho de Conclusão de Curso). Manaus (AM): Universidade Federal do Amazonas. 2016.

GONÇALVES, V. V. C. Influência do ciclo hidrológico em pescarias comerciais na Amazônia Central, Brasil. 2018. Dissertação (Mestrado em Ciências Pesqueiras nos Trópicos) - Universidade Federal do Amazonas, Manaus, 63 p. 2018.

ICMBIO. Dados Geoestatísticos das Unidades de Conservação Federais. Unidades de conservação por Bioma. Disponível em: 62 . Acesso em: jul, 2017.

ICMBIO. Diagnóstico Socioeconômico para Subsidiar a Elaboração dos Planos de Manejo das Unidades de Conservação Federais do Interflúvio Purus Madeira. Relatório do Diagnóstico Socioeconômico Dados Secundários. Produto 1, abr. Relatório, 547 p. 2014.

ICMBIO. Plano de Manejo da Reserva Biológica do Abufari. 2012.

IBGE, INSTITUTO BRASILEIRO DE GEOGRAFIA E ESTATÍSTICA. Contagem Populacional 2007 - Agregado por Setores Censitários. Rio de Janeiro. Disponível em: <http://goo.gl/vVO1sY>. Acesso em 10 de outubro de 2013. 2007. 
JUNK, J. W. As águas da região amazônica. In: SALATI, E, SCHUBART, H.O.R, JUNK, W.Y. E OLIVEIRA, A. E. (eds.) Amazônia: desenvolvimento, integração e ecologia. Editora Brasiliense. Brasília, CNPq. 45100p. 1983.

LIRA, T. M.; CHAVES, M. P. R. C. Comunidades ribeirinhas na Amazônia: organização sociocultural e política. Interações, 17(1):66-76. 2016.

LOUZADA, C. O. Impacto dos eventos enos (El Niño e La Niña) na agricultura familiar no Estado Do Amazonas. Formação (Online), 26(49). 2019.

MERCADO, D.S.; ALMEIDA, G.S; SILVA, Y. L. S.; CORREIA, J. S. C. Hábitos alimentares de ribeirinhos da Amazônia e contribuições das enchentes no agravo ao quadro de insegurança alimentar. Revista Saber Científico, Porto Velho, v. 4, n. 1, p. 14 - 18, jun. 2015.

MONTENEGRO, L. S.; SOUZA, L. A. Produção pesqueira e sua relação com as oscilações do ciclo hidrológico e o crescimento demográfico da cidade de Manaus-Am. Scientia Amazonia, 5(2), 14-23. 2016.

MORAES-ORNELLAS, V. S. Ecologia e conservação de porcos-do-mato no conhecimento tradicional indígena: Uma abordagem da Etnociência na Educação.Revista Brasileira de Meio Ambiente, 8(3). 2020.

MORCATTY, T.Q.; VALSECCHI, J. Social, biological, and environmental drivers of the hunting and trade of the endangered yellow-footed tortoise in the Amazon. Ecology and Society, 20(3). 2015.

NARDOTO, G. B. et al. Frozen chicken for wild fish: nutritional transition in the Brazilian Amazon region determined by carbon and nitrogen stable isotope ratios in fingernails. American Journal of human biology, v. 23, n. 5, p. 642-650, 2011.

RAMOS, M. M. Os efeitos de alterações ambientais sobre a produção de jaraquis (Semaprochylodus spp.) desembarcados na cidade de Manaus - AM (Tese de Doutorado). Manaus (AM): Universidade Federal do Amazonas. 2016.

SANTOS, A. F. Estudo de Variáveis Socioeconômicas e do Consumo Proteico Animal Na REBIO Abufari Tapauá/Amazonas. Trabalho de Conclusão de Cursão para obtenção do título de bacharel em Engenharia de Pesca. 2019.35p.

SAUER, S.; FRANÇA, F. C. Código Florestal, função socioambiental da terra e soberania alimentar. Caderno CRH, v. 25, n. 65, p. 285-307, 2012.

SHRIMPTON, R.; GIULIANO, R. Consumo de alimentos e alguns nutrientes em Manaus: 1973- 4. Acta Amazônica, 9 (1):117 - 41. 1979.

SILVA, L. S.; SILVA ALVES, H.; SILVA, D. W.; ROMANO, M. L. P. C. Alimentação na várzea amazônica: estudo dos hábitos alimentares de famílias ribeirinhas do município de Alenquer-PA. Revista Ciências Da Sociedade, 4(7), 177-206. 2020.

SILVA, A. L. Comida de gente: preferências e tabus alimentares entre os ribeirinhos do Médio Rio Negro (Amazonas, Brasil). Revista de Antropologia, 50(1), 125-179. 2007. 
SOUZA, L. A. Sustentabilidade ecológica e econômica da pesca de subsistência na Amazônia Central. Dissertação apresentada ao programa de Pós-graduação em Biologia Tropical e Recursos Naturais do convênio INPA/UFAM. 139p. 2003.

VALSECCHI, J.; EL-BIZRI, H.R.; FIGUEIRA, J.E.C. Subsistence hunting of Cuniculus paca in the middle of the Solimões River, Amazonas, Brazil. Brazilian Journal of Biology, 74(3): 560-68. 2014.

VASCONCELOS NETO, C. F. A. Atividade caça na Reserva de Desenvolvimento Sustentável Amanã (RDSA): uma abordagem de ecologia. Dissertação (Mestrado) - Instituto de Biociências da Universidade São Paulo. Departamento de Ecologia. São Paulo, 2016. 71 p. 